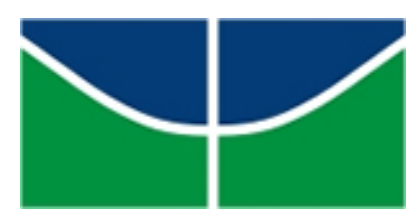

Universidade de Brasília Instituto de Letras

Departamento de Teoria Literária e Literaturas

Programa de Pós-Graduação em Literatura

\title{
VOZES CORDIAIS: O BRASIL VISTO A PARTIR DA OBRA DE MANUEL BANDEIRA
}

Bárbara Campos Pinto da Silva

Alexandre Simões Pilati

Orientador 


\author{
Universidade de Brasília \\ Instituto de Letras \\ Departamento de Teoria Literária e Literaturas \\ Programa de Pós-Graduação em Literatura
}

\title{
VOZES CORDIAIS: O BRASIL VISTO A PARTIR DA OBRA DE MANUEL BANDEIRA
}

\author{
Bárbara Campos Pinto da Silva \\ Alexandre Simões Pilati \\ Orientador
}

Dissertação de Mestrado Acadêmico apresentada ao Programa de Pós-Graduação em Literatura (PPGL) do Departamento de Teoria Literária e Literaturas (TEL), do Instituto de Letras (IL), da Universidade de Brasília (UnB), como requisito parcial à obtenção do grau de Mestre em Literatura.

Brasília/DF - 2017 


\section{BÁRBARA CAMPOS PINTO DA SILVA}

\section{VOZES CORDIAIS: O BRASIL VISTO A PARTIR DA OBRA DE MANUEL BANDEIRA}

Dissertação de Mestrado Acadêmico apresentada ao Programa de Pós-Graduação em Literatura (PPGL) do Departamento de Teoria Literária e Literaturas (TEL), do Instituto de Letras (IL), da Universidade de Brasília $(\mathrm{UnB})$, como requisito parcial à obtenção do grau de Mestre em Literatura.

Brasília, de de 2017

\section{Banca Examinadora}

Professor Dr. Alexandre Simões Pilati

Universidade de Brasília (UnB)

Professor Dr. Edvaldo Bérgamo

Universidade de Brasília (UnB)

Professor Dr. Wilson José Flores Júnior

Universidade Federal de Goiás (UFG) 


\section{AGRADECIMENTOS}

Agradeço a Deus, pela minha história.

Aos meus pais, Rosângela e Claudio, que me apoiam em tudo com tanto amor e confiança.

A Rogéria, pela presença e apoio em todas as fases da minha vida.

Ao Marco Túlio, pelo amor que se traduz em companheirismo e paciência.

Ao Alexandre Pilati, pela orientação dedicada e compreensiva, pelas aulas inspiradoras e pelas palavras que enriquecem a todos.

Aos professores Ana Laura e Edvaldo, pelas aulas também enriquecedoras.

A Andressa, pela amizade sempre pronta a ajudar.

Aos meus amigos, Anderson, Zuleika, Érica, Weuller, Nathália, Danilo, Carol, Karen, Mábia, Walter, Will, Larissa e todos aqueles que, mesmo não citados aqui, tornam qualquer caminho mais leve.

Ao Fernando, pela paixão inspiradora pela literatura e pelas palavras.

Aos meus alunos, por me darem um ânimo a mais na busca da educação e da reflexão. 


\section{RESUMO}

Este trabalho analisa como se dá a interpretação da modernidade do Brasil em poemas e em crônicas de Manuel Bandeira, especialmente nas obras Libertinagem e Crônicas da província do Brasil. A hipótese principal é a de que existe uma relação desses textos com as marcas sociais de cordialidade sintetizadas no pensamento do "homem cordial" de Sérgio Buarque de Holanda. A pesquisa apresenta, como ponto de partida, o contexto histórico da literatura das décadas de 20 e 30, com base em estudos de Antonio Candido, e, em seguida, analisa parte da fortuna crítica banderiana com enfoque no nacionalismo e no Projeto Modernista, considera, para isso, críticos como Davi Arrigucci Junior, Silviano Santiago, Sérgio Buarque de Holanda, Wilson Flores Jr., Yudith Rosenbaum, entre outros. O estudo também aborda criticamente discussões em torno da cordialidade. Considerando o "homem cordial" como aquele que exprime contradições brasileiras que têm suas raízes na colonização, o trabalho recupera estudos relacionados à formação do Brasil, como Casa Grande \& Senzala de Gilberto Freyre e Raízes do Brasil de Sérgio Buarque. A dissertação articula, ainda, tal discussão com a produção literária e intelectual brasileira e destaca estudos recentes sobre essa relação, como os de Jerônimo Teixeira, Silvana Moreli Vicente Dias e João Cezar de Castro Rocha. A partir da leitura dos textos literários, críticos e teóricos, a dissertação busca identificar e explicar a preocupação de conhecimento do Brasil na obra de Manuel Bandeira. Por isso, busca analisar poemas e crônicas bandeirianas selecionados e expor aspectos que, em nível de representação ou na forma literária, evidenciam a noção de cordialidade e mostram como os elementos nacionais se incorporam aos textos literários e revelam contradições sociais estruturantes da vida brasileira, destacando como a obra de Bandeira se alimenta de fundamentos da sociedade patriarcal mais atrasada para mostrar as contradições do progresso brasileiro.

Palavras-Chave: Literatura Brasileira. Manuel Bandeira. Identidade Nacional. Modernização. Homem Cordial. 


\begin{abstract}
This work analyzes the interpretation of Brazil's modernity in Manuel Bandeira's poems and chronicles, especially in the books Libertinagem and Crônicas da província do Brasil. The main hypothesis is that there is a correlation between these texts and the social marks of cordiality present in the concept of the "cordial man" by Sérgio Buarque de Holanda. The starting point of this work is the presentation of the literary historical context of the 20's and 30's based on the studies of Antonio Candido. Then, there's an analysis of the works on Bandeira that focus on nationalism and on the Modernism Project, considering critics such as Davi Arrigucci Junior, Silviano Santiago, Sérgio Buarque de Holanda, Wilson Flores Jr., Yudith Rosenbaum, among others. The study also deals critically with the discussions about cordiality. While considering the "cordial man" as the one who expresses the Brazilian contradictions rooted in colonization, this work recovers studies about Brazil's formation, such as Gilberto Freyre's Casa Grande \& Senzala and Sérgio Buarque's Raízes do Brasil. This discussion is then related to Brazilian literary and intellectual productions and highlights recent studies about this relation, such as the ones from Jerônimo Teixeira, Silvana Moreli Vicente Dias and João Cezar de Castro Rocha. From the readings of literary, critical and theoretical texts, this work seeks to identify and explain the concern about Brazilian conscientiousness in Manuel Bandeira's oeuvre. In order to do so, it seeks to analyze selected Manuel Bandeira's poems and chronicles and chronicles and show aspects that, in the level of representation or in literary form, evidence the notion of cordiality and show how the national elements incorporate themselves in the literary texts and reveal some structural social contradiction of Brazilian life emphasizing how Bandeira's literature feeds the fundamentals of the oldest patriarchal society in order to show the contradictions oh the Brazilian progress.
\end{abstract}

Keywords: Brazilian Literature. Manuel Bandeira. National Identity. Modernisation. Cordial Man. 


\section{SUMÁRIO}

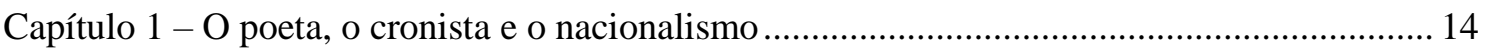

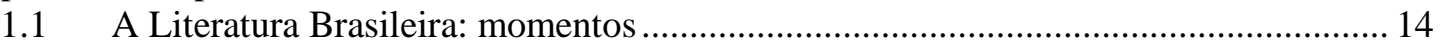

1.1.1 O contexto da década de 30 e a consolidação do modernismo ................................ 19





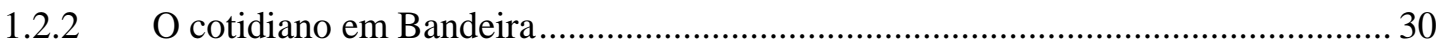

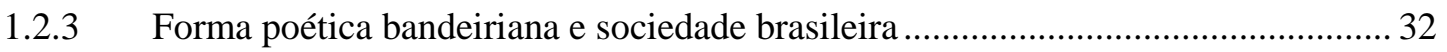

1.2.4 As vozes lírica e narrativa: espaço de ambiguidades ............................................... 35

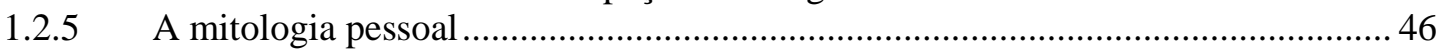



1.2.7 A mediação da infância e o passado que se faz presente ..........................................53

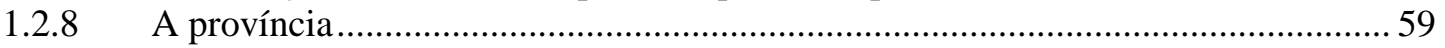



Capítulo 2 - Discussões sobra a questão do Homem Cordial e relações com a literatura brasileira

2.1 Pensar o Brasil: olhares sobre a história de um país colonial...................................... 64

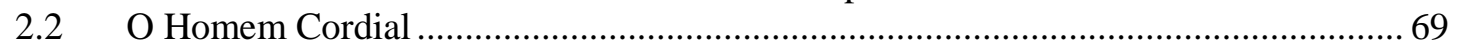

2.2.1 A cordialidade: problematizações propostas ao longo do tempo ………................. 75

2.3 A cordialidade, a literatura e o movimento modernista ................................................. 79

$2.4 \quad$ Um poeta moderno brasileiro e a cordialidade ............................................................ 81

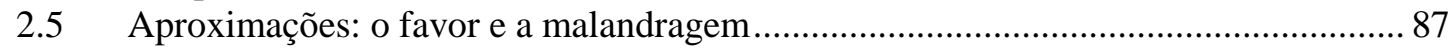

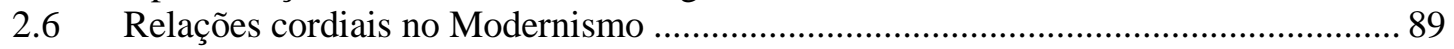



Capítulo 3 - O singular da ideia modernista de nacionalismo na obra de Manuel Bandeira ...... 96

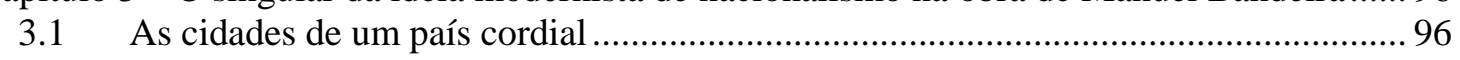

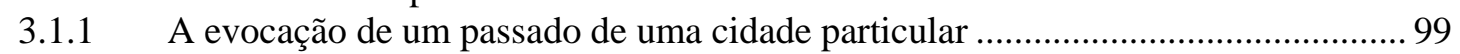

3.1.2 O Pernambuco de 1821 e o Pernambuco de Bandeira ............................................ 112

3.1.3 O progresso contraditório e quem está à margem ................................................... 117

3.1.4 Um mundozinho no Rio de Janeiro ..................................................................... 123

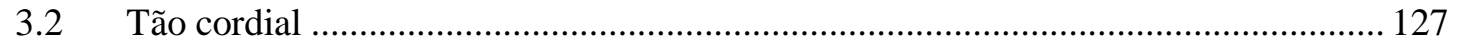

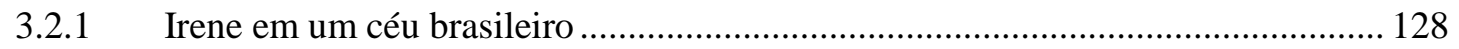

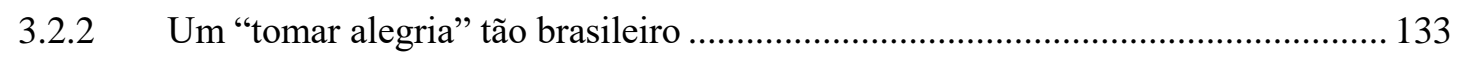

3.2.3 Os velórios cordiais e a tradição viva.................................................................... 139

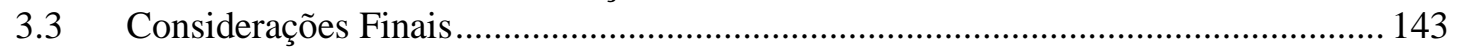

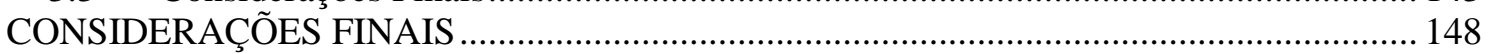






\section{INTRODUÇÃO}

A obra poética de Manuel Bandeira ocupa um lugar de grande importância no contexto da poesia do século XX no Brasil. Além de outras temáticas, muito conhecidas e trabalhadas por estudos críticos, como o amor, a morte e a infância, é recorrente e importante em sua obra a questão do nacional, que se faz presente em termos temáticos e estéticos, principalmente tendo em vista a vocação nacionalista do Modernismo.

Para avaliar a consistência dessa presença reveladora do nacional na obra de Bandeira, é preciso considerar as contribuições de diversos teóricos da literatura, que argumentam sobre a importância de conceber a literatura em conexão com a dinâmica histórica. Assim, é importante ter em mente que a questão formal não está isolada do processo histórico. Há uma relação da forma estética com a realidade, tomada como processo e história em movimento. Essa matéria histórica a literatura transfigura esteticamente através do trabalho do escritor. A arte, portanto, não se limita a ser um registro histórico e também não nos ajuda a ler mecanicamente a história, mas a problematiza, oferecendo uma experiência ao leitor, permitindo, assim, acesso a uma outra dimensão da história.

A arte está, pois, profundamente ligada à história humana. E, considerando o contexto contraditório da modernidade, assim como a vida cotidiana marcada pelo trabalho reificado, o trabalho artístico é o que possibilita propor questões. Como o trabalho literário não é separado da vida, ele pode ser desfetichizador, pois articula o singular e o universal, dando conta da representação do momento histórico em movimento. Para tanto, a arte parte da vida social, destaca-se da vida e transfigura esteticamente a história para voltar à vida.

É significativo, ao se considerar o período enfocado neste trabalho, pensar uma forma estética no contexto brasileiro de modernização, um país que carrega profundas contradições relacionadas ao seu passado colonial e a um capitalismo tardio. Nesse período, surge o pensamento do "homem cordial", desenvolvido por Sérgio Buarque de Holanda, uma realidade que exprime contradições brasileiras que têm suas raízes no processo histórico de colonização e que, para Sério Buarque, desapareceria com a modernização.

Pensando na relação dialética literatura e sociedade, faz-se necessário refletir sobre formas que dão a ver essa realidade brasileira de forma tensionada, não ignorando, portanto, as contradições formativas da vida nacional.

É com essa preocupação fundamental que serão analisados, nesta dissertação, poemas e crônicas de Manuel Bandeira. A análise irá se centrar em textos de Libertinagem, livro de poesia 
publicado em 1930, com textos entre 1924 a 1930, e de Crônicas da província do Brasil, obra de 1937 com textos publicados em jornais nas décadas de 20 e 30.

A escolha dessas duas obras se justifica pela proximidade temporal em relação às fases do Modernismo e também pela proximidade de questões e de temáticas, principalmente na revelação de aspectos da composição íntima do Brasil. A fase de produção dessas obras se dá na transição do Modernismo de 20, a conhecida fase heroica, mais otimista e mais ligada à renovação estética, e de 30, conhecida por ser uma fase mais crítica e ideológica. Em síntese, nas palavras de João Luiz Lafetá:

Enquanto nos anos 20 o projeto ideológico do Movimento correspondia à necessidade de atualização das estruturas, proposta pelas classes dominantes, nos anos 30 esse projeto transborda os quadros da burguesia, principalmente em direção às concepções esquerdizantes (denúncia dos males sociais, descrição do operário e do camponês), mas também no rumo das posições conservadoras e de direita (literatura espiritualista, essencialista, metafisica e ainda definições políticas tradicionalistas, como a de Gilberto Freyre) (...). Na verdade os dois projetos parecem corresponder as duas fases distintas da consciência de nosso atraso: nos anos 20 a tomada de consciência é tranquila e otimista, e identifica as deficiências do país compensando-se - ao seu estatuto de "país novo"; nos anos 30 dá-se início à passagem para a consciência pessimista do subdesenvolvimento, implicando uma atitude diferente da realidade. Dentro disso podemos concluir que, se a ideologia de país novo serve à burguesia (que está em franca ascensão e se prevalece, portanto, de todas as formas - mesmo destrutivas - de otimismo), a consciência (ou a pré-consciência) pessimista do subdesenvolvimento não se enquadra dentro dos mesmos esquemas, já que se aprofunda contradições insolúveis pelo modelo burguês. (LAFETÁ, 2004)

É importante evidenciar que essa divisão não ocorre de maneira absoluta nas obras do modernismo brasileiro, mas tal divisão didática nos ajuda a pensar a fase de produção das duas obras bandeirianas aqui destacadas, que se encontram com as representações de um Brasil mais otimista e as que evidenciam um reconhecimento do atraso brasileiro. A partir do enfoque nessas obra, este trabalho pretende examinar como as contradições da experiência histórica brasileira, assim como do processo de modernização, ganham forma nos textos bandeirianos, considerando a hipótese de que os textos sugerem uma relação com o pensamento do "homem cordial". Tal relação se verifica tanto nas imagens poéticas representadas quanto na forma poética de Bandeira, conhecida por uma simplicidade e pela atração ao leitor.

De acordo com essa abordagem que se pretende fazer da lírica e da crônica banderiana, é relevante considerar a importância do questionamento de Adorno (1983) sobre como a lírica, sendo a valorização da subjetividade, pode ser social. Em "Palestra sobre lírica e sociedade", ele discute essa relação dialética. Para ele, é pela negação que a lírica propõe em relação à 
sociedade, como algo profundamente individual e livre da utilidade e da objetividade, que ela se faz social.

A própria linguagem, também essencialmente dialética, é moldada aos impulsos subjetivos, mas, ainda assim, possui o seu significado referencial e faz referência à sociedade. Com a linguagem, o sujeito se torna mais que o próprio sujeito, fundamentado em uma corrente subterrânea coletiva. Assim, o sujeito poético representa um sujeito universal e relaciona-se com a realidade social antitética a ele.

A partir da lírica de Bandeira, veremos como elementos íntimos trazem a referência ao social, além de uma voz socialmente localizada que captura tensões de determinada época e local, sendo, ainda, universal. O universal de uma obra, para Adorno, existe pela densidade da sua individualização, pela expressão de emoções e experiências individuais. Parte disso, na lírica no século XX, elementos íntimos trazem a referência ao social. Nos poemas, deve ser encontrada no subjetivismo a relação com a sociedade, algo que deve ser mais involuntário, e não tematizado, no poema.

Essas considerações são importantes ao se pensar a poética de Bandeira, conhecida pela grande importância da história pessoal e de lances íntimos, mas com forte relação com aspectos sociais, que não devem ser desconsiderados em suas profundas tensões.

Outra relevante consideração a ser feita para este trabalho é sobre o gênero crônica, através do qual Bandeira também fez produções artísticas consequentes. As crônicas eram geralmente escritas para jornais, acompanhando o estilo simples, ou seja, uma escrita direta com uma linguagem simples, e dando importância ao cotidiano, o que, como iremos observar, é marca do poeta em sua obra em muitos momentos. Aqui, como foi dito, buscaremos pensar o gênero literário colado no seu processo histórico.

Em uma interessante análise, Carlos Drummond de Andrade $^{1}$ afirma a crônica como uma auxiliar da história. O grande poeta brasileiro reconhece que os documentos oficiais, os discursos, nunca dizem a verdade integralmente, e que o cronista, sem maior responsabilidade política, transmite aspectos culturais da vida brasileira que ajudam a compreender a realidade do momento histórico em que a história é contada. O poeta coloca a crônica não só com um sentido informativo, mas ultrapassa esse sentido, e tem também um sentido humano sugerido, sentidos que podem levar a uma compreensão do Brasil, já que discute questões da própria

\footnotetext{
${ }^{1}$ Comentários de Carlos Drummond de Andrade afirmando que a crônica é um instrumento de registro histórico no vídeo acessado pelo site http://www.contioutra.com/drummond-afirma-que-a-cronica-e-um-instrumentode-registro-historico/. Acesso em: 5 mai. 2016, 12:20:00.
} 
natureza brasileira. A crônica literária pode nascer de um fato político, o que também é ultrapassado, e, a partir da linguagem literária, pode sugerir diferentes questões.

Davi Arrigucci (1987), em "Fragmentos sobre a crônica", traça a discussão sobre o gênero partindo da concepção antiga da crônica, ou seja, a crônica histórica, que era compilações de fatos históricos. Porém, na modernidade, é um gênero que trata dos fatos corriqueiros do dia a dia, vinculado ao exercício cotidiano do jornalismo. Em relação a isso, o crítico afirma ser injusto "reduzi-la a um apêndice do jornal":

À primeira vista, como parte de um veículo de jornal, ela parece destinada à pura contingência, mas acaba travando com esta um arriscado duelo, de que, às vezes sai vitoriosa. Não raro, ela adquire, assim, entre nós, a espessura de texto literário, tornando-se pela elaboração da linguagem, pela complexidade interna, pela penetração psicológica e social, pela força poética ou pelo humor uma forma de conhecimento de meandros sutis de nossa realidade e de nossa história. (ARRIGUCCI, 1987, p. 53).

Dessa forma, entende-se a crônica em relação com o tempo histórico e é possível propor que textos de Crônicas da província do Brasil podem iluminar as questões expressas liricamente na poesia e vice-versa.

Considerando o abordado, importa expressar o ponto de vista histórico-sociológico para a análise literária de Bandeira que se pretende aqui. Assim, torna-se possível perceber a cordialidade, problema histórico e teórico brasileiro, também como problema formal. Em torno disso gira nossa suposição de que a cordialidade se encontra figurada nas contradições da obra de Manuel Bandeira, mostrando o profundo do Brasil.

Não se trata de reduzir a arte de Manuel Bandeira a aspectos cordiais, mas mostrar como essa categoria, que é uma realidade histórica, está captada de modo verdadeiro nos textos.

O fundamental para tal suposição centra-se na análise do nacionalismo apresentado na obra de Bandeira, fortemente percebido no período citado - década de 20 e 30. Para essa análise, este trabalho se divide em três capítulos.

No primeiro, intitulado "O poeta, o cronista e o nacionalismo", buscara-se fazer um recorte da fortuna crítica de Manuel Bandeira com enfoque no nacionalismo. Foi destacado, para isso, a importância da temática da Identidade Nacional na literatura brasileira, em especial no momento aqui discutido, em que se deu um contexto de processo de modernização problemática. Além disso, desenvolveram-se, nesse capítulo, comentários sobre esse contexto histórico e sobre as várias transformações do país. 
A partir disso, a obra de Manuel Bandeira é pensada na sua relação com o Projeto Modernista e na característica, destacada por Davi Arrigucci Júnior (1990), do simples cotidiano que oculta o complexo. Nesse contexto, vê-se, conforme destaca Godofredo de Oliveira Neto (2005), a consideração do nacional, um dos aspectos chaves do movimento modernista, na obra Libertinagem.

No capítulo 1, busca-se também mostrar problematizada a obra de Bandeira em relação à programática modernista, considerando a longa trajetória do trabalho poética de Bandeira, com críticos como Silviano Santiago e o próprio Sérgio Buarque de Holanda como analista da obra bandeiriana, entre outros.

Destaca-se também a importância de entender a categoria do cotidiano em Bandeira, a partir das atuais leituras do professor Wilson Flores Jr., e as recorrentes referências ao passado colonial, também consideradas por Mara Ferreira Jardim, estudiosa que analisa a contradição alegria e melancolia na obra aqui estudada.

Outro fator importante é a ambiguidade presente na própria voz que fala nos textos, em que se percebe a busca em criar uma empatia com o leitor, na tentativa de criar algo cordial, o que nos leva a questionar o estilo humilde de Bandeira, articulado com a característica de poeta menor. Fundamental também é a sua mitologia pessoal, conhecida da crítica e dos leitores de Bandeira. Além disso, busca-se observar a mediação da infância, a partir de estudos, para citar exemplos, de Sylvia Tamie Anan, considerando a crônica, e de Yudith Rosenbaum, considerando a obra lírica.

O estilo humilde, o cotidiano, a mitologia pessoal e a infância são aspectos que devem ser problematizados, com atenção às ambiguidades e às ironias, para analisar a relação forma poética e nacionalismo na obra de Manuel Bandeira. Propõe-se também alguns diálogos com outro poeta moderno brasileiro, Carlos Drummond de Andrade, sem desconsiderar as inúmeras diferenças das duas poéticas.

No capítulo seguinte, "Discussões sobre o "homem cordial” e relações com a literatura brasileira", pretende-se analisar a cordialidade e mostrar suas profundas relações com a literatura brasileira. Considera-se, então, o interesse por interpretações do Brasil entre 1920 a 1930 e discute-se Gilberto Freyre, Sérgio Buarque e Caio Prado. Em seguida, explica-se o conceito do "homem cordial" e expõe os principais questionamentos feitos em torno desse conceito ao longo do tempo, observando contradições que fazem parte da poética de Bandeira. Explicita-se, ainda, a cordialidade relacionada à produção literária e intelectual da década de 20 e 30 . 
No último capítulo, parte-se para uma análise mais detida de quatro poemas de Libertinagem e quatro crônicas de Crônicas da província do Brasil. Os textos são "Evocação do Recife", "Poema tirado de uma notícia de jornal", "Irene no céu”, "Não sei dançar", "Como era o Pernambuco de 1821", "A trinca do Curvelo", "Velório" e "Bahia". Esses textos, embora que de formas diversas, discutem o Brasil e o processo de modernização contraditório, tanto em relação à temática e à forma.

Em "Evocação do Recife", demonstra-se a persistência de valores do passado na problematização da modernidade com fatos íntimos passados ao leitor, algo intimamente relacionado com o "homem cordial", um conceito de um tipo que seria formado no meio rural e se caracteriza por destacar valores contrários aos valores da sociedade competitiva e capitalista inconciliáveis na realidade brasileira. Crônicas como "Como era o Pernambuco de 1821 " iluminam as relações com o passado analisadas no poema.

Já em "Poema tirado de uma notícia do Jornal", há a presença do Rio de Janeiro e, novamente, o progresso contraditório. Assim como em "Trinca do Curvelo", crônica que olha com afeto para os meninos pobres do Curvelo.

Com a humildade e a simplicidade características da obra de Bandeira, "Irene no céu" se apresenta com um tom harmônico que, contraditoriamente, apresenta uma violência de fundo. Tal contradição revela, de forma cordial, a violência do processo de colonização, a perpetuação de relação de dominação e de desigualdade de classes e a cordialidade batendo na fala dos personagens ou na própria voz lírica que parece, assim como nos outros textos, atingir o leitor para esses dilemas.

Essa característica da voz lírica também pode ser analisada em "Não sei dançar", assim como a dialética passado e presente. Além disso, as crônicas "Velório" e "Bahia" apontam representações de expedientes cordiais, com o tom de conversa amena e com o resgate de questões históricas.

A partir de tudo isso, esperamos demonstrar que, na obra de Manuel Bandeira, nas crônicas e nos poemas, há uma observação crítica da passagem modernizadora do Brasil mais rural para o mais urbano que capta o movimento do "homem cordial". 


\section{Capítulo 1 - $O$ poeta, o cronista e o nacionalismo}

Neste capítulo, será discutido um recorte da fortuna crítica bandeiriana sobre poesia e crônica com enfoque especial ao nacionalismo. O objetivo é pensar a obra de Bandeira no contexto do Modernismo e, assim, explicitar alguns aspectos analisados pela crítica que são fundamentais para a hipótese de que, considerando a construção poética de um eu-lírico que evidencia ambivalências e a construção da ideia de "poeta menor", além da conhecida mitologia pessoal alardeada pelo autor, a obra de Manuel Bandeira, em especial no contexto de 1930, sugere uma abordagem a partir da categoria da "cordialidade".

Considera-se que o ponto de vista histórico-sociológico é importante para uma análise literária, uma vez que o próprio texto sugere isso. É necessário considerar o contexto brasileiro, o qual, como será visto em todo o trabalho, encontra-se de maneira viva na estrutura da obra de Bandeira.

Para tanto, a pesquisa se apoiará na perspectiva de Antonio Candido, expressa em textos como "Literatura de dois gumes", "Literatura e subdesenvolvimento", "Literatura e cultura 1900 a 1945”, “A revolução de 30 e a cultura", a fim de fazer uma discussão a respeito do momento da literatura brasileira importante para a análise pretendida aqui.

Em seguida, faz-se um recolhimento de referências bibliográficas sobre Manuel Bandeira, reunindo textos clássicos e atuais com o objetivo de discutir a questão da cordialidade. Assim, volta-se a leitura para obras como Humildade, paixão e morte: a poesia de Manuel Bandeira, de Davi Arrigucci Jr., ou o prefácio de Estrela da vida inteira, de Antonio Candido e Gilda de Mello Souza, assim como os artigos atuais e fundamentais de Wilson Flores Júnior, entre outros.

\subsection{A Literatura Brasileira: momentos}

Conforme Antonio Candido (2000), no ensaio "Literatura de dois gumes", a literatura da América Latina sempre foi empenhada na construção e na aquisição de uma consciência nacional. Veremos como a obra de Manuel Bandeira está cheia de imagens poéticas relacionadas, explicitamente, ou não, com o tema da Identidade Nacional, que é central, então, para a literatura brasileira.

Além disso, nesse ensaio, Candido (2000) afirma que a formação da literatura do Brasil está ligada a aspectos da organização social, da mentalidade e da cultura brasileira, o que, em textos significativos, é incorporado, de forma dinâmica, à estrutura da obra. 
De acordo com ele, a adaptação da expressão europeia é um dos tópicos essenciais para pensar sobre a literatura no Brasil, que foi se desenvolvendo a partir da imposição dessa expressão que precisou assumir formas e modos diferentes em uma realidade diferente.

Candido (2000) explica, fugindo da prolongação romântica de fusão harmônica das três culturas - negro, índio e europeu, que a literatura escrita no Brasil foi primeiro a expressão da cultura do colonizador e depois do colono europeizado de uma posição dominante, além de sempre estar ligada aos mecanismos de dominação, o que a literatura como pretexto para imposição cultural religiosa ou as Academias no século XVIII com membros de uma elite que defendia as ações do colonizador exemplificam.

Esse crítico, pensando a realidade dialeticamente, afirma que "justamente pelo fato de manter relação com a realidade social, a literatura incorpora as suas contradições à estrutura e ao significado da obra" (CANDIDO, 2000, p. 168). É a partir dessa relação que a adaptação de uma literatura europeia no Brasil pode exprimir posições e sentimentos do país, tais como as divergências da elite da Colônia com a Metrópole que começaram a aparecer no século XVIII, o que está presente, por exemplo, no interesse na valorização do índio.

Em nossa tradição literária, definiu-se uma tendência que se caracteriza pela volta ao passado para justificar o presente e o padrão dominante, que se relaciona a uma visão nativista, porém aproximada dos ideais e das normas europeias, o que acontece com a idealização da natureza e do índio na época do Indianismo, período em que muitas populações indígenas já estavam destruídas e dissolvidas. Ao que serviu para justificar a mestiçagem de uma elite que herdou valores da Europa e, assim, a negação do negro escravizado.

No Romantismo, período que coincide com a Independência do Brasil, é central esse Indianismo como negação da colonização portuguesa e, assim, ligado ao desejo de inventar um passado mais nacional. A literatura, de acordo com Candido (2000), participava do esforço de criação da nação, sendo expressão da classe dominante e critério para a adaptação dessa classe à nova situação de urbanização e ao surgimento da classe média.

Em torno disso, o literato destaca que as formas cultas apreendidas da Europa na imposição e na adaptação de padrões culturais possibilitaram a contribuição da literatura para formação da consciência nacional. A ambiguidade que essas formas permitem reforçava os valores dominantes impostos de um lado, e, do outro, dava voz aos dominados, sendo assim, de dois gumes e ambígua, participando de uma realidade vasta e complexa, e nunca unilateral.

Desde o período colonial, a literatura brasileira, como fato estético e histórico, constituise como de dois gumes, pois foi arma do colonizador, mas, dialeticamente, contém a ideologia do colonizado. A partir do século XIX, passa a ser uma arma da elite que se baseia em ideias 
europeias, revelando seus interesses, mas é possível ver, na arte, os interesses do povo. Ou seja, a literatura tende para um lado, mas deixa ver o lado silenciado.

Além disso, apresenta-se uma literatura, que foi, em um primeiro momento, imposta, e, depois, foi se adaptando, em que se vê uma tendência de ser geral e particular, ou seja, percebese a partir dela um "duplo processo de integração e diferenciação, de incorporação do geral (no caso, a mentalidade e as normas da Europa) para obter a expressão do particular." (CANDIDO, 2000, p. 179).

A esses aspectos, acrescenta-se a discussão sobre a cultura e o problema do subdesenvolvimento, abordada no ensaio "Literatura e subdesenvolvimento", em que Antonio Candido (2000) traça aspectos que auxiliam na compreensão da criação estética de países subdesenvolvidos da América Latina, como o Brasil.

Considerando essa relação, observa-se que, até 1930, a perspectiva no país se apresentava otimista na literatura e na sociedade, a ideia era de um país novo, o que justificava o atraso, tal perspectiva Candido (2000) chamou de consciência amena do atraso. Há, na estética literária, um tom de deslumbramento e exaltação, favorecido pelo Romantismo, como na conhecida "Canção do exílio" de Gonçalves Dias. Assim, a ideia de nação se vincula à natureza exuberante, usada para engrandecer essa pátria e compensar o atraso material, cumprindo, então, nas palavras do crítico, o papel de ilusão compensatória.

A partir de 1930, e principalmente a partir de 1950, o que se manifestou foi a consciência catastrófica do atraso, caracterizada por uma compreensão do subdesenvolvimento que leva à luta. Nesse momento, a natureza aparece como problema político, destacando-se os solos pobres, e não mais a beleza.

Ainda, ao pensar a relação literatura e subdesenvolvimento, é significativo o que apresenta Antonio Candido (2000) sobre a dependência cultural natural por causa da colonização. Além disso, a debilidade cultural - relacionada com o analfabetismo, a falta de leitores reais etc. - fazia com que os escritores se voltassem para padrões europeus, acarretando na confusão de valores e na forte influência cultural, que pode ser positiva ou negativa. Com isso, o Romantismo no Brasil realiza a literatura brasileira em moldes europeus, dependência e influência da literatura francesa mais especificamente nesse período. Negar essas influências é negar a realidade.

Antonio Candido (2000) cita ainda, como superação da dependência, a possibilidade do escritor ter influências não mais só externas, mas também internas. Chama essa superação de causalidade interna, identificada em um segundo momento do Modernismo, já que os criadores do movimento derivam das vanguardas europeias, mas os poetas de 1930 tem como base esses 
precursores, assim como aproveitam as renovações estéticas anunciadas pelos modernistas da primeira fase.

Destaca-se, ainda, o Regionalismo, que, mesmo sendo considerado uma forma secundária e provinciana no meio de formas mais ricas, de acordo com Candido (2000), nos países subdesenvolvidos, ocorre como manifestação válida, e necessária. Tal tendência produziu formas estéticas alienantes e pictóricas, mas outras formas consequentes, ao que se destaca Vidas Secas de Graciliano Ramos, focalizando a contradição do progresso, desvendando a situação em uma complexidade.

$\mathrm{Na}$ fase da consciência amena do atraso, configurou-se de forma pictórica e como descoberta do país como tema literário. Já na fase catastrófica, o Regionalismo é percebido como consciência da crise com regiões que marcam o subdesenvolvimento do país, o que está presente, tanto no aspecto formal como temático, no romance de Graciliano Ramos citado. É significativo que, nas duas fases, a atenção geralmente é por áreas problemáticas, o que "é importante em literatura tão empenhadas quanto as nossas" (CANDIDO, 2000, p. 158).

Percebe-se sempre presente, na nossa literatura, o empenho em torno do nacional, ligada a diferentes perspectivas, regida, conforme Antonio Candido (2000), pela dialética do localismo e do cosmopolitismo. Um momento importante para levantar questões nesse sentido foi a fase chamada heroica do Modernismo, em que essa temática se envolve com uma preocupação de redescobrir a nacionalidade brasileira relacionada à pretensão de remodelar a Inteligência Nacional, que envolvia também uma ruptura de modelos acadêmicos e tradicionais. Buscavase uma mudança e uma liberdade no pensamento e no tratamento estético. Nas palavras de Mário de Andrade vinte anos depois da Semana de 22:

O movimento modernista foi o prenunciador, o preparador e por muitas partes o criador de um estado de espírito nacional. A transformação do mundo com o enfraquecimento gradativo dos grandes impérios, com a prática europeia de novos ideais políticos, a rapidez dos transportes e mil e uma outras causas internacionais, bem como o desenvolvimento da consciência americana e brasileira os progressos internos da técnica e da educação, impunham a criação de um espirito novo e exigiam a reverificação e mesmo remodelação da Inteligência Nacional. (ANDRADE, 2002, p. 253).

O Projeto Modernista acontece, então, em um período de transformações no mundo que reverberam em transformações na estética literária. Em países como o Brasil, o Projeto se configurou "em um período que sentia os efeitos de uma urbanização acelerada a se chocar com a herança rural e escravocrata, lutando contra a herança colonial. " (DIAS, 2013, p. 364). O 
Modernismo é, a partir desse contexto, presente na obra madura de Bandeira, escritor que se configura como um dos principais poetas brasileiros do século $\mathrm{XX}$.

Para Antonio Candido (2000), o Modernismo no século XX, assim como o Romantismo no século XIX, foi um momento decisivo. Ele divide a literatura do século XX, didaticamente, em três etapas: de 1900 a 1922, 1922 a 1945 e a partir de 1945. A partir do ensaio "Literatura e Cultura de 1900 a 1945", é possível estabelecermos e sintetizar um panorama, de forma didática, da literatura desses períodos.

Entre 1900 a 1922, a literatura se apresenta como de permanência e conservadora em relação aos traços pós-românticos. Candido (2000) se utiliza do que transformou o regionalismo da época, o conto sertanejo, para sintetizar a posição da fase: "que procurava, na sua vocação cosmopolita, um meio de encarar com olhos europeus as nossas realidades mais típicas. Esse meio foi o "tonto sertanejo"”. (CANDIDO, 2000, p. 120). Percebe-se, então, algo de essencialmente pictórico nesse naturalismo convencional. Considerando a poesia, salienta o Parnasianismo em relação a um academismo e o Simbolismo como núcleo de manifestações espiritualistas, destacando a obra de Cruz e Sousa e a de Alphonsus de Guimaraens. Pensando na crítica literária, afirma que há um prolongamento da crítica nacionalista do século anterior, mas sem a necessidade que tinha em sua origem de afirmação e independência nacional.

Comentam-se tendências estéticas de um idealismo simbolista se dissolvendo no penumbrismo, ao que Candido (2000) destaca Manuel Bandeira de Cinza das Horas e de Carnaval, e a de um naturalismo convencional se dissolvendo no diletantismo acadêmico. Com o Modernismo, haveria o rompimento dessas tendências.

Desde a Primeira Guerra Mundial, há o esboço de renovação literária, mas não separada da tradição. Foi com a Semana da Arte Moderna, em 1922, que se dinamiza essa renovação a partir da retomada histórica feita pelo Modernismo.

Nessa retomada, há a ruptura, e a originalidade na dialética do geral e do particular, relacionada à "libertação de uma série de recalques históricos, sociais, étnicos" (CANDIDO, 2000, p. 126) fundamental da fase heroica. Há também a citada inspiração nas vanguardas europeias, mas não como era antes. De acordo com Candido (2000), o Brasil estabelece outra ligação com o Ocidente europeu depois da Primeira Guerra Mundial, pela participação nos problemas sociais e pelo menor desnível cultural, além do surto industrial e das agitações sociais.

Destaca-se também o nacionalismo dessa geração, fundamental neste trabalho, relacionado à expressão livre para manifestar um país com tantos contrastes e mostrar nossas particularidades, se não totalmente desvinculadas, com uma perspectiva mais crítica em relação 
aos recalques históricos, ou seja, com a adesão a componentes antes não aceitos ligados à tradição popular, ao índio, ao mulato, ao negro etc. O que está, por exemplo, em Macunaíma de Mário de Andrade de forma problemática. É a partir desses aspectos, e destacando a influência de Manuel Bandeira, que Candido (2000) afirma que surge o estilo moderno na literatura brasileira.

Ademais, no importante decênio de 1930, que apresenta as tendências de questionamento político e social na prosa literária, destaca-se, para o crítico, a preponderância do problema, social ou político, o que pode ser a fraqueza da obra, mas se apresenta também como força. Além da ficção, há grande importância para o, também importante para este estudo, ensaio histórico-sociológico, associado às tendências do Modernismo, com a obra de Gilberto Freyre, de Sérgio Buarque e de Caio Prado Júnior, tendo o nacionalismo modernista impulsionado a investigação do Brasil.

Relacionado a essa investigação, destaca-se a centralidade da literatura na vida cultural e social do país, motivada pelos contatos com a Europa e, assim, pelo prestígio das humanidades clássicas, e pelo atraso local da instrução, entre outros fatores, influenciando para que os livros de intenção sociológica assumissem forma literária em vários momentos e a criação de mitos para orientar o pensamento. O que mostra mais uma vez a importância da literatura para a formação da consciência nacional e a pesquisa dos problemas locais.

Essa preocupação com o local, regional e popular, forte em vários momentos da literatura brasileira, em especial no Modernismo de 1920 e de 1930, enfraquece-se em 1940, momento em que se procura "fazer da expressão literária um problema de inteligência formal e de pesquisa interior". Assim, separou-se, ou buscou-se separar, a preocupação estética e a política em uma literatura que sempre pareceu se desenvolver na dialética do local e do cosmopolita.

\subsubsection{O contexto da década de 30 e a consolidação do modernismo}

Considerando a divisão didática feita por Candido em relação à literatura do século XX, convém, aqui, destacar a etapa que compreende 1922 a 1945 e o seu contexto histórico e literário, período da publicação de Libertinagem e de Crônicas da Província do Brasil, além de Raízes do Brasil, principais obras que orientam este trabalho.

O Brasil presenciou, desde o início do século XX, várias transformações sociais, políticas, econômicas e culturais. O país, que foi predominantemente rural, tinha as características sociais, políticas e econômicas girando em torno do café, e também da pecuária. 
Com base nisso, o poder se concentrava na mão dos proprietários rurais de São Paulo e de Minas Gerais.

Simultaneamente à importância do café, surgiram as indústrias, especialmente no Rio de Janeiro e em São Paulo, configurando também como classe dominante uma burguesia industrial, profissionais liberais e o Exército, que, de acordo com Alfredo Bosi (2006), tinha um papel político de revelo desde a proclamação da República.

Houve um crescimento da urbanização, além do surgimento da classe operária e dos movimentos sociais. Com um crescimento industrial incentivado em 1920, as cidades avançavam cada vez mais, assim como as massas populares. Além disso, há um aumento na imigração de europeus, tudo contribuindo para as mudanças na sociedade brasileira que se apresentavam de forma conflituosa com o tradicionalismo agrário. Para Bosi, "a nação desenvolvia-se à custa de graves desequilíbrios" (BOSI, 2006, p. 235) e, assim, o processo de modernização não se deu da mesma forma em todos os lugares e para todas as classes. $\mathrm{O}$ Nordeste se encontrava à margem e tendente ao arcaísmo, movimentos operários em São Paulo já mostravam problemas da industrialização, o que coexistia ainda com a tentativa de interferência militar no poder.

O poder se preservou, então, por mais de três décadas, entre as oligarquias de São Paulo, de Minas Gerais e do Rio Grande do Sul. O acirramento na disputa pelo poder levou à Revolução de 1930, conduzida pela cúpula militar, e Getúlio Vargas se tornou presidente.

A revolução de 30 foi, conforme ilustra Antonio Candido (1984) no texto A revolução de 1930 e a cultura, um marco histórico que gerou um movimento de unificação cultural e evidenciou os fenômenos de transformação iniciados nos anos 20. Não só em relação à literatura, as novas condições econômico-sociais marcaram toda a vida cultural do país.

Em relação ao ensino, é significativo os ideais da escola nova, além da busca liberal por renovar a formação das elites dirigentes com a instrução elementar ligada ao voto secreto e ao aumento das carreiras de nível superior. Com isso, Candido traz uma discussão sempre muito atual em um país como o Brasil: "nós sabemos que (ao contrário do que pensavam aqueles liberais) as reformas na educação não geram mudanças essenciais na sociedade, porque não modificam a sua estrutura e o saber continua mais ou menos como privilégio" (CANDIDO, 1984, p. 28).

Ainda assim, na década de 30, tem-se um aumento das escolas e a criação de universidades, agora com uma difusão das ciências humanas e sociais e, portanto, do pensamento crítico frente ao esquema tradicional. 
No tocante à arte e à literatura, Candido (1984) ilustra uma tomada de consciência radical dos intelectuais, além de obras marcadas pelo engajamento político, religioso ou social, mesmo quando os intelectuais não tinham consciência clara dessas preocupações ideológicas. Ilustra também o enfraquecimento da literatura acadêmica, a extensão das literaturas regionais com significados nacionais e a incorporação das inovações formais e temáticas do modernismo. Cita que, nos anos 30, também, faz-se presente a produção madura de poetas como Manuel Bandeira frente à consolidação da poética modernista, produção esta que tanto nos interessa neste trabalho.

Além disso, Antonio Candido (1984) apresenta a "realidade brasileira" como um dos conceitos-chave do momento, relacionadas à "consciência social”, à busca de reinterpretar o nacional, ao interesse pelos estudos sobre o negro e ao empenho pela explicação de fatos políticos. Isso confirma o destaque, como já citado, para obras de estudo como o livro de Gilberto Freyre, Raízes do Brasil, de Sérgio Buarque, e Formação do Brasil Contemporâneo, de Caio Prado Júnior.

Dessa forma, o período foi marcado por mudanças na educação, na literatura e nos estudos brasileiros, mudanças em que o trabalho de editoras, como a José Olympio, permitindo a difusão da literatura moderna, exerceu papel importante. Houve também consequências estéticas, como, na poesia, exemplifica-se pela tensão entre o verso tradicional e o verso livre. Também, apesar do pouco progresso para as classes mais baixas, o movimento revolucionário de 30 levou a uma maior consciência social e, na arte, o interesse pelas coisas brasileiras.

De acordo com Fausto, "um novo tipo de Estado nasce após 1930, distinguindo-se do Estado oligárquico não apenas pela centralização e pelo maior grau de autonomia como também por outros elementos. " (FAUSTO, 2006, p. 182). Esses elementos - uma atuação econômica a fim de promover a industrialização, proteção e apoio da classe trabalhadora e da burguesia industrial, além do papel central do Exército a fim de estabelecer a ordem - influenciaram no capitalismo nacional e em um processo de modernização, o que, como vimos, vinha sendo desenhado décadas antes.

Considerando os fatores explanados, assim como a impossibilidade de se pensar o Brasil sem os desdobramentos da escravidão e de uma influência do passado colonial que sempre marcaram a sociedade brasileira, esse processo de modernização se deu de forma tardia, além de ter como característica uma exclusão social das camadas mais pobres. Daí o desequilíbrio social que Sérgio Buarque de Holanda (1963) diz ter surgido no Brasil, o que é sintetizado por ele na noção de cordialidade, que envolve o passado como momento constitutivo do moderno, 
em que valores do passado se fazem presente na modernização de forma que se mantêm privilégios e prerrogativas.

Dentro desse contexto contraditório da sociedade, desenrola-se o Projeto Modernista. Para Alfredo Bosi,

Nos países de extração colonial, as elites, na ânsia de superar o subdesenvolvimento que as sufoca, dão as vezes passos largos no sentido de atualização literária: o que, afinal, deixa ver um hiato ainda maior entre as bases materiais da nação e as manifestações culturais de alguns grupos. É verdade que esse hiato, coberto quase sempre de arrancos pessoais, modas e palavras, não logra ferir senão na epiderme aquelas condições, que ficam como estavam, a reclamar uma cultura mais enraizada e participante. E o sentimento do contraste leva a um espinhoso vaivém de universalismo e nacionalismo, com toda a sua sequela de dogmas e anátemas. (BOSI, 2006, p. 326).

Em complemento, o crítico destaca a coexistência da sedução de modelos da cultura europeia e as exigências do povo brasileiro e múltiplo, reconhecendo, como fruto maduro do movimento, em uma exploração feliz das potencialidades formais da cultura brasileira, a poesia de Bandeira.

A obra de Bandeira, como verificaremos em especial em Libertinagem, vive a tensão de uma sociedade em que a contradição em relação à modernidade e à tradição faz-se presente. Acerca dessa tensão, é importante considerar que, na literatura brasileira, há "a necessidade de junção entre adequação técnica e tendência local, entre cosmopolitismo e provincianismo, entre modernidade e tradição, com grau variável de complexidade crítica e mediação" (DIAS, 2013, p. 359), o que, na obra bandeiriana resulta em formas, com caráter sobretudo ambivalente, que sugerem contradições estruturais da sociedade brasileira.

\subsection{A obra de Manuel Bandeira}

\subsubsection{O modernismo bandeiriano}

Manuel Bandeira foi, além de poeta, cronista, ensaísta e tradutor e possui uma obra grande e complexa, mesmo se intitulando poeta menor. É amplamente estudado pela crítica, que dá principal atenção à sua poesia, sob os mais diferentes aspectos. Aqui, refletiremos sobre estudos que nos ajudam a construir a perspectiva crítica pretendida neste trabalho, que se liga à ideia de nacionalismo como aspecto formal nas manifestações literárias bandeirianas. A fortuna crítica muitas vezes, considerando outras temáticas conhecidas na obra de Bandeira, 
como a morte, dá pouco enfoque à essa temática do nacionalismo, mesmo sendo um aspecto fundamental na estética de Bandeira.

É uma temática central se formos pensar o poeta nos limites do movimento Modernista. Ao analisar a obra de Bandeira nesse contexto, Davi Arrigucci Junior (1990), um dos principais analistas bandeirianos do Brasil, em Humildade, paixão e morte: a poesia de Manuel Bandeira, destaca a importância do mais simples cotidiano e o prosaico da vida moderna, além do uso do verso livre, aproximado da fala corriqueira e popular. Essa obra crítica vai, com análises de poemas, como veremos, revelando o complexo do aparentemente simples dos versos desse poeta, não esquecendo a produção em prosa, sintetizando características formais e temáticas, mas muitas vezes sem sublinhar as ambivalências fundamentais de uma obra como a bandeiriana, como veremos.

De acordo com o estudo de Arrigucci, Bandeira foi o poeta mais importante na introdução do verso livre no Brasil em um momento que a estética parnasiana ainda dominava. A técnica se aproxima ao prosaico e à fala brasileira, ajustado ao interesse modernista pela vida de todo dia o que faz parte da preocupação com a realidade brasileira.

A preocupação com a expressão da realidade brasileira é clara em Manuel Bandeira, vinculada com a questão da fala do povo, algo concretamente brasileiro e essencial à pesquisa modernista, ao que, em Bandeira, relaciona-se, no Itinerário, também ao contato no Rio de Janeiro. Um exemplo está no verso "Porque ele é que fala gostoso o português do Brasil”, muito utilizado pela crítica para abordar essa questão da fala.

Godofredo de Oliveira Neto (2005), em estudo publicado recentemente na obra Libertinagem \& Estrela da Manhã, intitulado "Bandeira, modernista brasileiro", afirma a importância da obra Libertinagem para consolidar o Modernismo brasileiro, destacando o nacional presente nessa variante brasileira do português claramente discutida no verso citado de "Evocação do Recife" e um afastamento de uma ideologia poética tradicional em "Poética", aspectos chaves da programática modernista.

Configura-se, então, um Bandeira modernista com uma poesia que, segundo Godofredo, "ajuda a fixar a nacionalidade brasileira, que consolida as letras e as coisas nacionais" (NETO, 2005 , p. 6). O crítico continua citando aspectos que influenciam a essa relação com o Modernismo, tais como a natureza irônica e a exaltação do cotidiano, recorrendo ao burlesco, à ironia e ao humor.

Para ele, esse espírito nacionalista e de renovação estética continua, com temas do folclore negro e sociais, na obra Estrela da manhã, e na constante presença do cotidiano banal que desentranha significados simbólicos. Além disso, mostra, com o poema "Balada das três 
mulheres do sabonete Araxá", os aproveitamentos da tradição literária (Delfino, Rimbaud, Oscar Wilde, Shakespeare) e pessoal de forma crítica. O que também articula o poeta ao Modernismo. Essa apropriação é uma atitude moderna, e traz novas perspectivas ideológicas e questionamentos.

Um exemplo de como a apropriação aparece no Modernismo é o poema "A descoberta", de Oswald de Andrade, em que é feita uma apropriação de trechos da carta de Pero Vaz de Caminha, mas com um novo sentido, através da ironia possível pelo trabalho estético que coloca os trechos específicos em versos, marcados também pela falta de pontuação. A apropriação comum ao Modernismo discute, muitas vezes, com uma tradição brasileira, além de possibilitar, no caso do poema citado, um convite ao leitor a um outro olhar, mais crítico, sobre o passado brasileiro. Tal volta ao passado, com a busca de uma reorganização crítica, também se faz importante na literatura do século XX.

É o que mostra a obra de Bandeira, por exemplo, nas várias representações que consideram a tradição da religião católica, imposta pelo colonizador, com acréscimo de sentidos, como em "O anjo da guarda", "Macumba do pai Zusé", entre muitos outros. Percebem-se, por exemplo, contrapontos com outras religiões, como as de matriz africana, além de vários poemas que trazem nomes de santos de forma problematizada. Há também a conhecida questão alma e corpo, que é aproveitada com mudança de sentido, colocando a alma como perecível e a matéria como permanente, em "Momento num café" e em "Boi morto", entre outros poemas. Apesar do aproveitamento desses aspectos religiosos ser feito de forma crítica, a obra bandeiriana também sugere aspectos tradicionais, assinalando a dialética tradição e modernidade.

Há, nesse sentido, a representação da intimidade, comum aos brasileiros, com os santos da Igreja, a qual, de acordo com Sérgio Buarque de Holanda (1963), é uma característica do "homem cordial", que aproxima os santos ao homem, os familiariza e configura uma religiosidade oposta a ordens e rituais.

Sérgio Buarque afirma que:

A popularidade, entre nós de uma Santa Teresa - Santa Teresinha - resulta muito do caráter intimista que pode adquirir seu culto, culto amável e quase fraterno, que se acomoda mal às cerimônias e suprime as distâncias. É o que também ocorreu com nosso menino Jesus, companheiro de brinquedo das crianças (...) (HOLANDA, 1963, p. 140-141).

É assim, com uma informalidade, que os santos vão ser constantemente representados nos poemas, o que podemos comprovar no poema "Oração a Teresinha do Menino Jesus": 
“Quero Alegria! Me dá Alegria!/ Santa Teresa!/ Santa Teresa não, Teresinha.../ Teresinha... Teresinha.../ Teresinha do menino Jesus.” (BANDEIRA, 2009, p. 138).

A mudança para o diminutivo marca uma familiarização com a santa e dá destaque ao caráter desse culto intimista preferido pelos brasileiros. O tom é de conversa, há o uso da fala popular brasileira com a próclise em "me dá alegria!", e o diminutivo carrega, além dessa intimidade, uma ironia, sendo um recurso para convencer a santa, conhecida pela sua alegria em meio às dores, a atender o pedido de alegria.

Se é o objeto de pedido, nota-se também que há a ausência dessa alegria, há uma melancolia, outro paralelismo analisado por vários críticos como aspecto importante. A repetição da presença de Santa Terezinha na obra pode se relacionar com o culto amável e intimista pelo qual é conhecida, além de ser associada à alegria, o que tem relação dicotômica com a melancolia.

No poema "Oração a Nossa Senhora da Boa Morte", de Estrela da manhã livro posterior à Libertinagem, o eu-lírico retira o diminutivo da terminação Tereza, já que coloca que a santa nunca realizou o que pedia: "Fiz tantos versos a Teresinha.../ Versos tão tristes, nunca se viu!/ Pedi-lhes coisas. O que eu pedia/ Era tão pouco! Não era glória.../ Nem era amores... Nem foi dinheiro.../ Pedia apenas mais alegria:/ Santa Teresa nunca me ouviu! (...)" (BANDEIRA, 2009, p. 154).

Nesse mesmo poema, há uma aproximação das santas com algo mais humano, como nos versos: "Para outras santas voltei os olhos./ Porém as santas são impassíveis/ Como as mulheres que me enganavam" (BANDEIRA, 2009, p. 154). Ao invés de uma exaltação, há uma humanização. Há uma apropriação relacionada à tradição de nomes de santas para falar das mulheres que enganaram o eu-poético, que recorre a várias e se desengana: "Desenganei-me das outras santas/ (Pedi a muitas, rezei a tantas).” (BANDEIRA, 2009, p. 154). Essa aproximação irônica, e distante do sagrado, repete-se em outros poemas, tais como "Balada de Santa Maria Egípcia”, "O menino doente”.

A partir dessa dessacralização, construída através de uma humanização, só a princípio relacionada à cordialidade em que é característica a humanização do rito, o poema reorganiza a tradição e dialoga de maneira mais crítica e universal.

Arrigucci (1990) comenta sobre o aproveitamento de diferentes matérias nos textos, cita as que cotidianamente estão na vida dos brasileiros, a notícia de jornal, as falas populares, as cantigas infantis, além da tradição brasileira, das casas de engenho, das festas religiosas etc. Aproveitamentos e atualizações combinados, na totalidade dos poemas, com o subjetivo do poeta, elementos psicológicos e histórico-sociais. 
Relacionado a isso, Arrigucci (1990) traz também, na análise detalhada de "Poema tirado de uma notícia de jornal", um exemplo fundamental da literatura brasileira moderna que pressupõe, já no título, que a poesia pode ser tirada de algo prosaico e cotidiano, e até contrário à poesia, o que revelou uma mudança profunda da atitude estética e uma abertura à experiência da cidade moderna. $\mathrm{O}$ crítico cita que, ao extrair do jornal um texto, há a mudança de sentido e a renovação da busca de compreensão do leitor. Cria-se uma narrativa outra, diferente da do jornal, mas que com ela ainda mantém relações, mesmo que contraditórias.

Nesse poema, ainda, a tradição do trágico se atualiza, é o que mostra Arrigucci (1990) na associação com um caráter dionisíaco, o que coloca a narrativa de um marginal de uma cidade moderna na dimensão do universal e dentro de uma complexa tradição.

Há também, em uma atitude moderna, uma mescla de gêneros, a narrativa se fazendo cada vez mais presente na lírica. E uma aproximação do subjetivismo lírico com a realidade cotidiana e sua abertura para um maior objetivismo. É o que está presente no poema citado, que analisaremos mais detalhadamente no Capítulo 3 deste trabalho.

Além desses elementos modernos da atitude estética, No Itinerário da Pasárgada, o narrador já afirma desde criança ter se impregnado com o realismo da gente do povo e ter sido influenciado pela fala popular, elementos que, depois, o relaciona com o Modernismo. Afirma também não se reconhecer tão parte do movimento, como Mário e Oswald, apesar de afirmar a forte influência em suas obras, aponta uma colaboração com restrições. Deixa-nos claro que o clima modernista foi fundamental em algumas obras, as quais nos importa muito neste trabalho, não só de versos, mas também de prosa:

O Morro do Curvelo, todos esses amigos e, naturalmente, outros laços de afetos - eis o clima dentro do qual compus os livros de versos $O$ ritmo dissoluto, Libertinagem, grande parte de Estrela da Manhã, e o livro de prosa Crônicas da Província do Brasil, este uma seleção de artigos que durante algum tempo escrevi para o Diário Nacional, de São Paulo, e para A Província do Recife, na fase em que ela foi dirigida por Gilberto Freyre. (BANDEIRA, 2012, p. 90).

Nota-se, ao citar os amigos e os laços de afetos, a importância de um clima cordial ao falar da sua obra, o que vai estar muito presente nas cartas trocadas pelos intelectuais da época, como notou Silvana Moleri Vicente Dias (2013) ao analisar a cordialidade nas correspondências dos escritores, o que será melhor aludido no Capítulo 2 deste trabalho e que problematiza as relações de amizade como fundamentais nas avaliações literárias e críticas. 
Além disso, a oralidade, a informalidade, a presença do elemento popular e outros elementos característicos do Modernista estão na estrutura da obra de Bandeira, e muitos críticos consideram estar em seus poemas de forma natural, até pelo fato do escritor parecer não se prender tão intimamente comprometido com o aspecto programático movimento, como Mário de Andrade, por exemplo. O que se observa também quando se considera a temática do nacional, que, conforme Mara Ferreira Jardim (2007), Bandeira não assume, como outros modernistas, o compromisso explícito de abordar esse tema, mas a realiza em seus textos.

Sérgio Buarque de Holanda (1944), ao pensar nesse contex to do modernismo, no ensaio "O mundo de um poeta" em Cobra de Vidro, comenta que Bandeira, apesar de ter sido quem primeiro empregou o verso livre no Brasil, não abandona os ritmos tradicionais. Além disso, afirma que "a verdade é que ele não obedecia a nenhum programa definido e não se prendia a compromissos." (HOLANDA, 1944, p. 28).

Para Arrigucci (1990), ele se destaca entre outros modernistas pela naturalidade e pela simplicidade. Considera a relação dessa naturalidade com o fato de Bandeira não acatar uma norma definitiva, vai do parnasiano para o antiparnasiano, do clássico e do padrão culto para o popular, do verso metrificado ao verso livre, além de criticar exageros modernistas e equilibrar o moderno e o clássico: "se nos anos de irradiação intensa do movimento modernista domina o aproveitamento da fala brasileira, nem por isso abdicará do uso culto. ” (ARRIGUCCI, 1990, p. 140).

Silviano Santiago (1998), em edição crítica de Libertinagem e Estrela da manhã, problematiza a relação da poesia bandeiriana com o Modernismo. Para tanto, traz o comentário de Carlos Drummond de Andrade sobre a Semana da Arte Moderna, o qual afirma uma não repercussão dessa Semana em Minas Gerais, já que não se liam os jornais paulistas, e que sua primeira Semana da Arte Moderna foi aos quinze anos, ao ler um poema de Bandeira. Assim, o poeta mineiro afirma uma precedência de dicção poética moderna em poemas publicados, posteriormente, em 1919, na obra Carnaval.

Além disso, Santiago percebe a ironia de Bandeira, coexistindo com uma coincidência cronológica que ele tem com o modernismo, no seguinte trecho do Itinerário de Pasárgada: “o que no entanto poucos verão é que muita coisa que ali parece modernista, não era senão o espirito do grupo alegre de meus companheiros diários naquele tempo". O crítico considera que, para o poeta, o convívio noturno, ou as relações afetivas e cordiais, importava mais que os manifestos da geração.

Santiago (1998), diferentes dos outros críticos citados, distancia Bandeira do Projeto Modernista e destaca a voz narrativa de Itinerário como também construtora dessa distância, 
pois privilegia as relações pessoas ou a sua vivência pessoal ao aspecto programático do movimento.

Com os estudos críticos citados, assim como com essas diferenças de perspectivas que a crítica de Santiago mostra, percebe-se que muito do que se envolve com modernismo na obra de Bandeira, como a fala popular, também se aproxima de outros aspectos da obra e da vida de Bandeira, como a vivência no Curvelo abordada no Itinerário. O que não nega um vínculo com o movimento, mas destaca a importância da trajetória poética de Bandeira como um autor moderno.

Nesse sentido, essa discussão ajuda a revelar a naturalidade de Bandeira em relação ao modernismo comentada por alguns estudos citados aqui, assim como a sua importante influência para o movimento, sendo considerado por muitos como percursor do movimento, o que destaca Mário de Andrade ao chamá-lo de São João Batista do Modernismo brasileiro, salientando o desenvolvimento do poeta com o verso livre, fundamental à nova estética.

Assim, ao pensar a obra de Bandeira nesse contexto da programática modernista, devemos considerar a sua longa trajetória do seu trabalho poético, tal como a sua formação penumbrista, com aspectos simbolistas e parnasianos; sua experiência com a morte; a experiência pessoal com o povo brasileiro, que ele faz questão de acentuar; o contato com os artistas da primeira geração modernista; as viagens; o diálogo tanto com poetas tradicionais como modernos; entre muitos outros aspectos que integram uma totalidade significativa e em que se encontra dialeticamente tradição e modernidade.

Elisabeth Hess (2014), em dissertação intitulada "Uma análise do realismo na constituição do eu-lírico na obra de transição de Bandeira", ao investigar as transformações das obras anteriores a Libertinagem, percebe a tensão da ruptura e da conservação dos significados no tempo e como ocorre a articulação da subjetividade e da objetividade no novo que aparece na obra bandeiriana, composta de avanços e retomadas que articulam o passado e o presente na totalidade da lírica.

Ela afirma que é no proveito da tradição que ancora a experimentação estética de Bandeira, além de comentar uma disposição em preservar formas e imagens da tradição em relação a sua poética modernista, intimista e atenta às possibilidades contidas no cotidiano.

Estabelece também a questão das dificuldades representativas que o "eu" da lírica no Brasil, reportado a moldes europeus, em uma fase do desenvolvimento do capitalismo tardio, com a constante ameaça da alienação. Em uma volta ao cotidiano e à simplicidade, a forma do eu-lírico se reelabora na obra de Bandeira e capta o processo social contraditório brasileiro, sem percepção disponível dessas contradições. 
Em Ritmo Dissoluto, obra publicada em 1924, apesar de surgirem produções bem diversas, já se apresentam poemas representativos da nova fase de representação bandeiriana, em que se observa a simplificação das imagens, o verso livre, a incorporação de elementos prosaicos e cotidianos com a tensão do sofrimento da vida comum apreendida poeticamente. Nessa fase de transição, a poética de Bandeira, além de cair em temas profundamente subjetivos, como a solidão e a morte, é influenciada pela transformação social do período e pelas indagações da forma poética que vão sendo propostas pelo movimento modernista. Há, então, de acordo com Hess (2014), a necessidade de uma superação em sua pesquisa poética e interiorização de algo estranho ao individualismo.

Hess (2014) evidencia, pensando essa necessidade e as oscilações de um maior ou menor subjetivismo e objetivismo, a transformação do ritmo na poética de Bandeira e destaca, com poemas da obra citada, que:

Na rima que apanha a objetividade de "Santa Maria Egipcíaca", prevalece já certa tensão entre a força lírica da objetividade e a aproximação dos sinais divinos à alienação do homem de olhar duro. Na métrica regular de "O espelho", as rimas repetidas não têm qualquer função conciliatória, nem de tensão. Elas fluem como se houvesse uma natureza própria que lhes atribuísse a consonância dos sentidos, às vezes esbarrando na própria gratuidade e falta de tangibilidade. Aqui, em "Berimbau", chegamos a outra forma de contraposição entre objetivismo e rimas. Nesse poema de tom altissonante, destacam-se as variações rítmicas e sonoras dos versos, pois a nossa aproximação do sentido está fortemente transpassada por esses elementos. O que acontece é que não poderíamos concluir o que vem primeiro na economia deste poema: a experiência de brincar com as palavras, que tanto atraía a Bandeira, desde o convívio com o pai, ou a tendência modernista, que aflorara mesmo antes de existir um movimento, pela recordação da infância e da apreciação da cultura oral, folclórica mesmo, daqueles tempos evocados pela pobreza no Rio de Janeiro. $O$ fato é que neste poema a apreciação estética do falar popular e da sonoridade da língua portuguesa se desenvolve por uma forma extremamente modernista. (HESS, 2014, p. 32).

Também em Ritmo Dissoluto, Hess (2014) percebe um modo de articulação com a objetividade significativo em "Meninos carvoeiros", uma associação com a cultura popular sem condicionamentos impostos pelos limites do capitalismo. Nesse poema, conforma análise dessa estudiosa, mesmo com a falta aparente da presença explícita de referência individual, em um distanciamento contraditório, exemplificado nos primeiros versos que apontam uma cena a ser observada ("Os meninos carvoeiros / Passam a caminho da cidade.”), há a presença forte da voz lírica com uma impressão afetiva ("adoráveis carvoeirinhos que trabalhais como se brincásseis"). Essa impressão prevê a nova perspectiva do objetivismo lírico de Bandeira. 
Considerando esse desenvolvimento da poética de Bandeira e a sua obra parte do Modernismo, mas não presa ao programa, percebe-se uma força nacionalista que está na própria forma poética de modo aparentemente simples, muitas vezes em poemas com matérias íntimas. Como ainda comenta Sérgio Buarque,

A célebre "Evocação do Recife" é antes evocação do que descrição, e aparenta-se por esse lado a algumas das suas poesias de fundo mais subjetivo e íntimo, como "Profundamente", ou "Noite Morta". Muitas vezes o material lírico que lhe fornece a realidade sensível tem como fundo de quadro um país mítico ou ausente, que tanto pode ser a maravilhosa Pasárgada com o mundo das suas insistentes recordações, o mundo que refletiria, se fosse mágico, o honesto espelho de "Versos de Natal" (HOLANDA, 1994, p. 33).

Dialeticamente, nesses poemas, o eu-poético de Bandeira traz o nacional sendo profundamente subjetivo e íntimo, a partir das suas recordações de infância e com a morte sempre norteando sua produção. Com essas insistentes recordações e nesse país mítico que comenta Sérgio Buarque, há, como veremos, mais de nacional do que parece, há a ausência e a presença de um Brasil patriarcal na modernidade, através desse saudosismo constante de uma infância e de referências do país de quando era menino.

\subsubsection{O cotidiano em Bandeira}

A noção de cotidiano é, muitas vezes, um aspecto tido como importante do Modernismo e fundamental na obra de Bandeira. Sérgio Buarque de Holanda (1944) também comenta a importância poética do cotidiano na obra de Manuel Bandeira, e, trazendo um trecho em que Bandeira critica o modo como falam do Brasil, diz:

As coisas triviais, quotidianas, podem valer mais para ele do que as realidades vistosas. E isso não por simplismo voluntário, mas certamente pela convicção de que há nelas mais importância, maior interesse poético. Foi essa convicção que êle próprio chegou a sugerir em uma das suas Crônicas da Província do Brasil, quando criticou, com razão, certa atitude literária de nossos escritores: 'Falamos de coisas brasileiras como se as estivéssemos vendo pela primeira vez, de sorte que em vez de exprimirmos o que há nelas de mais profundo, isto é, de mais quotidiano, ficamos nas exterioridades puramente sensuais.' (HOLANDA, 1944, p. 33).

Essa noção é essencial em Bandeira e muito comentada pela fortuna crítica. O que falta, várias vezes, é uma maior problematização desse cotidiano, que, lembrando a crítica feita por 
Wilson José Flores Jr. (2012), é comumente considerado sem ambivalências em uma obra essencialmente ambivalente.

O professor, considerando o sentido de cotidiano na literatura moderna e no contexto capitalista, além das perspectivas de pensadores como Henri Lefebvre, Agnes Heller e Walter Benjamin, o compreende como "uma categoria histórica, ligada à tomada da memória e da subjetividade por lógicas que levam a uma regulação minuciosa e mutiladora da vida, mas que não provocam reação organizada e sim paralisia, medo e sensação de impotência" (FLORES, 2012).

A cotidianidade na vida moderna é marcada pela ambiguidade de um mundo fragmentado, com a repetição, além da manipulação e da mecanização do tempo, o que se relaciona com a perda de experiência postulada por Benjamin, que liga a memória pessoal e coletiva, ao mito e à tradição. O que se faz presente, então, é o cotidiano com essa perda e uma alienação do sujeito e da sociedade. Assim, a ideia de cotidiano abrange seu caráter ambíguo presente em textos artísticos.

Nessa perspectiva, os poemas de Bandeira, os quais exigem uma leitura mais ativa e atenta aos movimentos da subjetividade lírica, carregam elementos que negam uma leitura conciliatória. O cotidiano nesses poemas, como alerta Flores (2012), é muito mais alienado, mercantilizado do que parece, e cheio de associações com o passado colonial. Pensando assim, o professor aproxima Bandeira dos principais autores da literatura do século XX, como Drummond, apesar do tratamento diferente, os dois poetas se inserem nessa arte moderna.

Wilson Flores (2012) realiza essa leitura atenta às ambivalências em vários poemas. O poema "Balõezinhos", tomando como referência a análise do crítico, coloca os balõezinhos como mercadoria indispensável (“Sente-se bem que para eles ali na feira os balõezinhos de cor são a única mercadoria útil e / [verdadeiramente indispensável. "), o que se contrapõe ao cotidiano frio e preso a necessidades, mas ainda é mercadoria de um vendedor, um trabalhador pobre e informal. Além disso, o poema não mostra que as crianças pobres conseguem os balões que desejam ("E em torno do homem loquaz os menininhos pobres fazem um círculo inamomível de desejo/ [e espanto.”)

Flores (2012) destaca as repetições do poema, como "olhos muito redondos" e "grande balõezinhos muito redondos", que enfatizam o desejo, associando os balões e as crianças. Destaca também o movimento entre desejo e espanto, indicado, por exemplo, pela adversativa "no entanto" ("No entanto a feira burburinha"), além da apresentação desse cotidiano marcado pela reprodução automática e vazia, também dada por repetições, às vezes com pequenas 
variações significativas, como em "Vão chegando as burguesias pobres,/ e as criadas das burguesias ricas".

$\mathrm{Na}$ análise, destaca-se o frequente uso de diminutivos, um outro aspecto formal, que, assim como as repetições, é recorrente no conjunto da obra de Bandeira. Há um contraste em relação às diferentes acepções que esse recurso pode demonstrar (afetividade, ironia ou uma ideia depreciativa). No poema, é afetivo ao se referir aos menininhos e aos balõezinhos, e depreciativo ao se considerar burguesinhas, barraquinhas etc.

Ao analisar a obra de Bandeira na perspectiva que se pretende aqui, é importante conferir atenção ao uso frequente desses diminutivos, já que, de acordo com Sérgio Buarque de Holanda (1963), a tendência a esse uso é um aspecto linguístico do povo brasileiro, sendo marca da cordialidade, pois serve para nos familiarizar com as pessoas ou objetos. Em muitos poemas bandeirianos, esse aspecto vai ser importante, seja para falar com ternura de algo, o que lembra o caráter marcadamente emotivo do "homem cordial", seja para ironizar ou para, relacionandose com a pesquisa Modernista do Brasil, retratar a fala popular e a essência do caráter brasileiro, e, ainda, para a produção de um efeito familiar para o leitor. É necessário destacar que o recurso é por si só irônico e ambivalente.

No poema analisado por Flores, é clara a ironia que carrega o sufixo "inho" em relação a suas diferentes acepções, além do caráter emotivo quando se trata dos menininhos, contribuindo para uma atmosfera aparentemente harmônica e com ternura que o poema cria.

Por fim, o recurso, sendo também irônico e atribuindo depreciação, contribui para a tensão do poema que o professor desejou explicitar. Tal tensão permanece ao lado da ternura no movimento entre desejo e obstáculo, contrapondo humanização e desumanização de forma equivalente, e não conciliatória, demonstrando um cotidiano mediado pela mercadoria, com o dinheiro sendo determinante no sonho dos meninos pobres, além dos trabalhadores pobres, que confirmam o dia a dia marcado pelas relações reificadas da sociedade capitalista.

\subsubsection{Forma poética bandeiriana e sociedade brasileira}

Também considerando a poesia de Bandeira como é, ou seja, irônica e ambígua, e o cotidiano mercantilizado e alienado, Flores (2015) analisou o poema "Vou-me embora para Pasárgada" e explicitou a relação forma poética e processo social brasileiro.

Nessa análise, presente no artigo "Vou-me embora para Pasárgada: devaneio e processo social", além de mostrar o eu-lírico operando ações que contrapõem um cotidiano produtivo, mostra toda uma base patriarcal, com um mundo a serviço do sujeito. Flores (2015) foge ao 
simples desejo de evasão e da atmosfera amena do poema, apresentando uma problematização à história brasileira, recupera um mundo colonial, além de um saudosismo da escravidão. Para ele, o cenário luminoso e quente é perpassado por uma violência de fundo, mostrando um contato, não esperado, com o nosso passado colonial e que se relaciona tão bem com a cordialidade implícita no verso "Lá sou amigo do rei", verso que se aproxima de relações políticas pautadas na família, no afetivo.

Para demostrar como o poema, que é irônico, sugere isso, destaca sua construção em redondilhas e um ritmo que confere uma atmosfera luminosa e ofegante. São apresentadas atitudes que negam a ordem de um cotidiano mercantilizado e rotineiro ("Lá a vida é uma aventura"), assim como também faz as brincadeiras infantis ("subirei no pau de sebo"). Há, de acordo com o crítico, em Pasárgada, um devaneio patriarcal em harmonia e solidão, o sujeito do poema é um menino sozinho brincando: "Montarei em burro brabo/ Subirei no pau de sebo/ Tomarei banhos de mar!"

Destaca também o mandonismo de uma mentalidade escravista, presente, por exemplo, no verso "mando chamar mãe-d'água (...)" e em outros que colocam as personagens femininas a serviço do eu lírico. Esses aspectos mostram um sujeito de uma realidade social baseada na escravidão, como expressa Flores (2015), Bandeira nunca foi um proprietário rico, mas a experiência da escravidão sempre se mostra presente na sociedade brasileira. Assim,

oscilações ligam-se a ambivalências ao mesmo tempo pessoais e históricas. Bandeira vinha de uma família que possuía vínculos com os engenhos de Pernambuco e que fora, por isso, diretamente afetada pelo esfacelamento do modo de vida patriarcal e pelo rebaixamento dessa experiência frente à modernização do país, o que conduziu parte dos destronados a cultivar um sentimento ambivalente de desprezo e admiração pelo progresso. Por outro lado, seu pai e seus tios eram todos profissionais liberais. O pai, engenheiro, trabalhou ativamente em estradas de ferro e na modernização de portos pelo país. (FLORES, 2015, p. 320).

Wilson Flores (2015) atingiu uma chave de interpretação coerente e, somente com esse olhar às ambivalências, é possível perceber problematizada, em Bandeira, a relação forma poética e nacionalismo, além de uma arte que nos ajuda a refletir sobre um processo social fortemente atravessado pelo passado colonial.

Mara Ferreira Jardim (2007), em tese que aborda a questão da Identidade Nacional nos versos bandeirianos, intitulada Manuel Bandeira: Tão Brasil, assim como Flores, mostra como o passado colonial brasileiro se faz presente e, a partir disso, como Bandeira realizou a 
abordagem em torno do nacionalismo de forma consequente, com o humor e a melancolia sendo traços formais, traços esses também formadores da identidade nacional brasileira.

Ou seja, o uso dialético do humor e da melancolia dos poemas, em especial de Libertinagem, analisados por Mara (2007), é também do caráter do povo brasileiro, que usa do humor em momentos de melancolia. Nas palavras da autora:

Entendemos, a partir de Schlegel, que o riso irônico contém também o seu contrário, a melancolia. Sem ela, a ironia não se realiza. A ironia, nas poesias modernistas de Bandeira, atua como uma forma de ver não só o individual (o poeta ironiza sua própria miséria), como o coletivo, a terra e o povo brasileiro. (JARDIM, 2007, p. 70).

Nessa perspectiva, Mara traz a profunda relação com o passado colonial, a partir de um olhar crítico da obra Retrato do Brasil de Paulo Padro, descaracterizando o Brasil como o país da alegria, mostrando uma tristeza que pode ser relacionada à submissão vinda da nossa história de colonização e escravidão, o que em diferentes momentos aparece, mesmo que inconscientemente, em nossa literatura.

A alegria, tão característica brasileira, deve ser problematizada, evidenciando-se uma melancolia. Tal alegria, na perspectiva de Mara (2007), compensa uma miséria vinda de nossa situação colonial. Aí que se encontra a relação alegria e melancolia, uma alegria que revela uma situação melancólica. Como afirma Antonio Candido (2000), é uma ilusão compensatória, assim como a valorização da natureza muitas vezes usada para compensar o atraso material do país.

A melancolia, em Manuel Bandeira, vai ser uma característica marcante em toda a obra, aparecendo mesmo em obras que trazem as alegrias da infância e sendo muitas vezes relacionada com a temática da morte, como podermos comprovar no poema "Profundamente" de Libertinagem, essa melancolia aparece principalmente na sua fase mais simbolista e mais marcada por um subjetivismo, porém continua em sua obra mais modernista.

Para ela, então, o tom irônico e melancólico dos poemas aponta essa duplicidade, que é brasileira e do poeta. O poema "Não sei dançar" exemplifica essa sugestão com um tom de humor que é melancólico, além de uma festa de carnaval, símbolo da alegria brasileira, comumente observada de forma mais crítica nos textos bandeirianos.

No poema em questão, que será melhor discutido no capítulo 3 deste trabalho, em um primeiro momento, o eu lírico, que assiste a um baile, rejeita a tristeza, "eu tomo alegria", mas "quanto mais reafirma sua alegria, mais releva o estado melancólico" (JARDIM, 2007, p. 92), 
retratando cenas de uma tristeza tão típicas do poeta ("Sim, já perdi pai, mãe, irmãos./ Perdi a saúde também.’). E, em um segundo momento, aparece:

o não menos melancólico retrato do país, corroído por problemas políticos, econômicos e de saúde pública; por preconceitos, latentes no salão -, mas que, ainda assim, teima em beber a alegria do último baile de carnaval. (JARDIM, 2007, p. 94).

O que nos comprova os versos: "A filha do usineiro de Campos/ Olha com repugnância/ Para a crioula imoral. [...]/ Ninguém se lembra de política...” (BANDEIRA, p. 126, 2009), entre outros.

Entende-se, assim, a obra de Manuel Bandeira como matriz de ambivalências que apresentam um sujeito brasileiro que vive nas tensões do país fortemente atravessado pela sua história colonial.

\subsubsection{As vozes lírica e narrativa: espaço de ambiguidades}

A partir do olhar crítico conferido às ambivalências, podemos pensar uma forma relacionada com a característica da cordialidade na arte modernista de Bandeira. Uma hipótese para a análise é a voz dos textos, sendo ela testemunha de um tempo e, mesmo intensivamente subjetiva, expressa o coletivo, além de considerar um leitor implícito brasileiro e cordial. Isso parece estar presente não só na poesia, mas também na prosa.

É necessário ressaltar que, em relação à produção em prosa, também é perceptível pouca atenção da crítica. As crônicas bandeirianas, por exemplo, são, muitas vezes, analisadas como ponto de apoio para o entendimento de poemas, como na análise que Davi Arrigucci (1990) faz do poema "Boi morto". Nessa análise, para uma melhor observação dos sentidos do poema, usa-se a crônica "Cheia! As cheias!..." como apoio, mostrando semelhanças e diferenças entre os gêneros que veremos mais à frente.

O fato de as crônicas serem usadas na análise de vários poemas já anuncia uma relação entre esses gêneros na obra como um todo. Arrigucci (1990) afirma que, na crônica, o leitor habitual reconhece espaços já conhecidos na leitura dos poemas, como os personagens e os lugares da infância do eu lírico.

Essa relação não é apenas temática, mas também formal, e está na voz que fala nos textos. Essa voz é mais um "espaço de ambiguidades", entre tantos outros que compõem a forma bandeiriana. 
Tal consistência ambígua pode, talvez, ser mais facilmente percebida nas crônicas, em que há maior interesse pela informalidade, uma publicação mais imediata, e, assim, possivelmente, com menor número de revisões, que deixariam escapar aspectos, relacionados intimamente ao contexto de produção, que não escapariam tão claramente em outro gênero etc, como já é afirmado na própria Advertência de Crônicas da província do Brasil, obra que reúne algumas crônicas que Bandeira escrevia para jornais brasileiros entre 1929 e 1933:

A maioria destes artigos de jornal foram escritos às pressas para A Província do Recife, Diário Nacional de São Paulo, e O Estado de Minas de Belo Horizonte. Eram crônicas de um provinciano para a província. Aliás este mesmo Rio de Janeiro de nós todos não guarda, até hoje, uma alma de província? O Brasil todo é ainda província. Deus o conserve assim por muitos anos! (BANDEIRA, 2008, p. 12)

Percebemos que advertência semelhante continua na obra Flauta de Papel, a qual é uma reedição de Crônicas da província do Brasil:

As minhas crônicas da Província do Brasil, cuja edição, que é de 1936, se achavam há muito esgotadas, não mereciam reimpressão (...). Decidi, pois, reeditar apenas o que nelas me pareceu menos caduco, juntando-lhes numerosas crônicas escritas posteriormente, a maioria para o Jornal Brasil. Chamei ao volume Flauta de Papel, querendo significar, com tal título, que se trata de prosa para jornal, escrita em cima da hora, simples bate-papo com os amigos. Não lhes dou, a estes escritos, outra importância senão a de ver em alguns deles o registro de fatos que desapareceriam comigo, se eu não os lançasse ao papel. (...) (BANDEIRA, 2013, p. 5).

Em tese dedicada ao estudo de crônicas bandeirianas, intitulada Crônicas da vida inteira, Sylvia Tamie Anan (2006), além do sentido já aludido em relação ao nome da obra Flauta de Papel, ou seja, uma associação com a infância, relacionando o nome flauta de papel à magia que está presente no poema "Infância" de Belo Belo, destaca uma magia, de uma infância idealizada, a qual cria empatia com o leitor. Sylvia complementa:

Através da escolha do título, Bandeira estende, pela publicação das crônicas, que alcançam um público relativamente amplo, aquele seu primeiro "gesto de magia", que não raramente suscitam uma reação inesperada do cronista: algumas crônicas de Flauta de Papel e Andorinha Andorinha registram a resposta de leitores a determinadas afirmações suas no texto de jornal, deixando o poeta muitas vezes surpreso. Na réplica a esses leitores, vemos que Bandeira considerava os seus textos frequentemente desvalorizados pelo público, que ampliava tanto a sua importância quanto o seu significado. Uma prova disso são as duas posteriores publicações em prosa: a segunda edição de Flauta de Papel, publicada pela editora José Aguilar um ano depois da 
primeira e contida no segundo volume de Poesia e Prosa, e a coletânea Andorinha Andorinha reúnem quase exclusivamente textos escolhidos por leitores e amigos do poeta. (ANAN, 2006, p. 15).

Como se vê, em relação às crônicas, o narrador quer acentuar a característica de escritas "às pressas" e, assim, a de uma maior informalidade e a busca de um contato com o leitor. A ideia da própria voz que fala no texto justificar essa característica pode se aproximar à insistência do poeta em se caracterizar como poeta menor.

No texto "A vida aos rés-do-chão", Antonio Candido (1993) argumenta a crônica como um gênero menor que, por essa simplicidade, com "o ar despreocupado de quem está falando coisas sem maior consequência" e com um tom menor de coisa familiar, fica mais perto de nós e "pode dizer as coisas mais sérias e empenhadas por meio do ziguezague de uma aparente conversa fiada”. Essa aparente conversa fiada é, então, fundamental ao pensarmos o gênero e é discutida nas advertências das obras de crônicas aqui citadas.

Ainda na Advertência de Flauta de Papel, percebe-se, ao associar as crônicas a um simples bate-papo com os amigos, uma aproximação com o leitor. Destaca-se essa característica de o gênero crônica ter um tom de conversa sem compromisso, o que, então, a voz narrativa faz questão de reafirmar na advertência e em outros momentos.

O leitor é colocado como partícipe de uma conversa de amigos. Além disso, há a construção poética de uma humildade bandeiriana característica que, nessa perspectiva sobre uma consideração de um leitor, precisamos problematizar.

No Itinerário de Pasárgada, a voz narrativa afirma:

Na minha experiência pessoal fui verificando que o meu esforço consciente só resultava em insatisfação, ao passo que o que me saía do subconsciente, numa espécie de transe ou alumbramento, tinha ao menos a virtude de me deixar aliviado de minhas angústias. Longe de me sentir humilhado, rejubilava, como se de repente me tivessem posto em estado de graça (...). Tomei consciência de que era um poeta menor, que me estaria sempre fechado o mundo das grandes abstrações generosas; que não havia em mim aquela espécie de cadinho, pelo calor do sentimento, as emoções morais se transmudam em emoções estéticas: o metal precioso eu teria que sacá-lo as duras penas, ou melhor, as suas esperas, do pobre minério das minhas pequenas dores e ainda menores alegrias. (BANDEIRA, 2012, p. 40).

O Itinerário, uma obra autobiográfica sobre a sua produção artística, também mostra que, especialmente em uma obra como a de Bandeira, dados biográficos podem auxiliar em construções de sentido, desde que não levem a uma explicação simplificadora, e "acentua as dificuldades da compreensão crítica, cuja tarefa passa sempre pela integração dinâmica dos 
mais diversos e contraditórios componentes numa totalidade significativa" (ARRIGUCCI, 1990, p. 259). Mas, sendo uma forma artística, não é sempre literal, há ironias e desvios de sentidos. Portanto, é necessário questionar o que é proposto como referencial e considerar o caráter ambíguo da linguagem, assim como em suas crônicas, que também trazem dados autobiográficos.

Em relação a esse aspecto, Wilson Flores (2015) também chama atenção ao comentar a afirmação de Bandeira, sobre "Vou-me embora para Pasárgada", que associa o poema a um desejo de evasão do menino tuberculoso, colocando a ideia, muito repetida pela crítica, da poesia como apaziguadora de insatisfações, que pode fornecer consolo a outros insatisfeitos. Segundo o professor, "ao proceder assim, Bandeira joga fora da história e das tensões sociais o sofrimento subjetivo." (FLORES, 2015).

O trecho já transcrito do Itinerário é exemplo dessa defesa da poesia como algo para aliviar as angústias. Além disso, Bandeira se afirma como poeta menor e nega as grandes abstrações da convenção poética, importando-se mais com pequenas dores e as menores alegrias. Ou seja, constrói-se um discurso de performance humilde, do qual um leitor comum, de um país caracterizado como provinciano, pode se sentir íntimo. Além do que, nessa obra, ele dá uma importância ao alumbramento, à poesia como intuição, mas, diversas vezes, veremos como é fruto de um trabalho que tem um desejo de atrair o leitor. O trabalho de construção poética também se afirma em Itinerário, em paralelo com esse discurso do alumbramento, destacando a ambivalência.

É preciso, então, sempre problematizar os relatos da prosa bandeiriana, o que certa crítica costuma analisar como certo e sem ambiguidades. Os casos recorrentes de lembranças da infância, de súbita inspiração, a caracterização como poeta menor, tudo deve ser observado com a desconfiança necessária a um discurso artístico como o aqui estudado:

É no mínimo curioso que o discurso humilde, meio que o Cristianismo inventou, modificando a retórica clássica, pela mescla dos níveis de estilo, em que o alto pode ser contido no baixo, como uma forma de difundir facilmente uma doutrina complexa, como um modo de veicular amplamente um conteúdo divino, se preste aqui para dar expressão acessível e aceitável a algo que ao mesmo tempo se busca e se teme. (ARRIGUCCI, 1990, p. 131).

Davi Arrigucci Jr., assim como outros estudiosos, destaca a característica central do simples que oculta o complexo de uma poética que "persegue uma elevada emoção através das palavras mais simples de todo o dia." (ARRIGUCCI, 1990, p. 15). O crítico apresenta esse aspecto como definidor principalmente do que chama de fase madura de Bandeira, um período 
mais modernista que decorre, como vimos, de um processo de experiência acumulada e, para Arrigucci, o momento da obra Libertinagem. É preciso problematizar essa noção de "fase madura", sobretudo relacionada a um autor como Bandeira, sendo tal noção mais relacionada a uma importância dada ao Modernismo do que à própria trajetória poética de Bandeira.

É importante destacar também que essa humildade bandeiriana é aparente e ambivalente, é construída poeticamente e de forma sutil, mesmo que, em muitos poemas, a simplicidade possa implicar essa performance discursiva de humildade que confere um tratamento simples para assuntos elevados ou para assuntos cotidianos que carregam algo a mais. Como acontece no discurso cristão, há a consideração de um leitor, o qual Bandeira busca alcançar com a simplicidade para dizer o complexo. Na busca em criar empatia com esse leitor, a voz nos textos é simbolicamente humilde.

Gilberto Mendonça Teles (1998), no texto “A experimentação poética de Bandeira em Libertinagem e Estrela da manhã", explicita o vasto conhecimento literário de Bandeira a partir de dados biográficos e cita o desempenho técnico na construção dos poemas, o que se contrapõe com a humildade, simbolizada, por exemplo, no poema "Andorinha":

O contrário do que havia dito no poema "Andorinha", de Libertinagem, quando escreveu: "Passei a vida à toa, à toa...". Este sentido de humildade e de modéstia é bastante reiterativo em sua obra, tanto na poesia como na prosa (crônica e crítica), funcionando como verdadeira análise em face de sua biografia, sem grandes lances político-sociais, mas profundamente cheia de significação humana, tão "cheia de tudo", como escreveu na "Canção do vento e da minha vida”, de Lira dos cinquent'anos. (TELES, 1998, p. 109).

Vejamos o poema citado:

\section{Andorinha}

Andorinha lá fora está dizendo:

- "Passei o dia à toa, à toa!"

Andorinha, andorinha, minha cantiga é mais triste!

Passei a vida à toa, à toa...

(BANDEIRA, 2009, p. 139)

O pequeno poema é composto de versos livres e duas estrofes paralelas, em que a segunda ironiza a primeira. Nele, percebe-se que a humildade comentada por Teles (1998) construída poeticamente no verso "passei a vida à toa, à toa" é reforçada pela simplicidade do vocabulário e pelo ritmo musical de todo o poema, dado pelas repetições da palavra 
"andorinha", da cantiga "passei o dia à toa, à toa" (em que, no último verso, troca-se dia por vida) e do fonema /a/. Salienta-se que o poema foi musicado, como tantos outros de Bandeira.

Há nele contrastes que levam à construção de uma ternura que também é melancólica. É uma cantiga com um ritmo luminoso, mas é uma cantiga triste ("minha cantiga é triste"). Apesar de falar de algo melancólico, sobre passar a vida à toa, o poema apresenta, com sua musicalidade, uma ternura e uma claridade. Também, apesar dessa claridade e da sensação de algo diurno, a catinga da andorinha traz algo que se falaria no fim do dia e em uma atmosfera mais noturna. Ainda, a palavra Andorinha, que, pela presença do sufixo "inha", carrega da ternura do diminutivo, traz a palavra dor.

Tais contrastes que se relacionam com a afirmação sobre passar a vida à toa abrem questionamentos. O poema ambíguo e irônico problematiza, assim, o trabalho poético. A diferença de pontuação que acompanha a locução popularmente utilizada para dizer que a pessoa não faz nada no canto da andorinha e na do eu-lírico também é significativa, sendo que as reticências deixam o sentido da frase em aberto, é, assim, questionável.

Além da relação com a humildade nesse poema, Teles (1998) percebe a construção de um estilo aparentemente humilde também na oposição entre o cuidado em informar que tudo é fruto da intuição e o trabalho real do poeta, assim como tudo que foi aprendendo sobre a poesia, exemplifica essas informações com o comentário sobre "Vou-me embora para Pásargada" no Itinerário, o qual afirma ser esse o poema de mais longa gestação e deixa claro um ato de conscientização artística. Percebe também que as opiniões críticas de Bandeira conscientes e fundamentadas sobre outros artistas, como Guilherme de Almeida, Mário de Andrade, entre outros, exemplificam a humildade contraditória que existe no alumbramento bandeiriano, pois um discurso de alumbramento afasta a ideia de estudo técnico e da conscientização artística, contribuindo para a construção de uma simplicidade e de uma humildade aparente. O próprio Itinerário, como citado, já destaca a ambivalência entre os alumbramentos e o estudo técnico e demonstra uma tênue construção em torno da poesia como fruto da intuição.

O estudioso goiano, nesse ensaio, explicita a ambiguidade da voz do sujeito humilde em uma crônica sobre Guilherme Almeida, de Crônicas da Província do Brasil, na qual faz um elogio para o poeta caracterizado como o maior artista do verso em língua portuguesa. Esse elogio também é, no fundo, dirigido ao próprio Bandeira:

Guilherme de Almeida é o maior artista do verso em língua portuguesa. Realmente, ele brinca com todos os recursos de técnica já conhecidos, inventa a cada passo novas combinações surpreendentes, faz o que quer, faz positivamente o que quer. O pobre do poetinha comum precisa das dez sílabas 
bem medidas para dar o ritmo do decassílabo: Guiherme, não, arranja a mesma coisa com onze sílabas ou nove. (BANDEIRA, 2006, p. 131).

Nessa mesma crônica, Bandeira cita que a imagem poética do coração batendo nos joelhos é uma das coisas melhores que conhece em poesia, algo que se aproxima da imagem do "grande coração transverberado" do próprio Bandeira, e mostra uma afetividade exagerada e cordial.

Aqui, além de considerar essa humildade em relação à sua significação humana, vemos a importância dos lances político-sociais, a qual Teles parece não considerar - como cita no trecho transcrito do seu ensaio. A humildade bandeiriana pode apresentar uma significação política, história e social na medida que dá a ver uma voz, que considera um leitor, em um espaço social bem determinado e revela contradições profundas desse espaço.

Faz-se necessário citar, ainda, um trecho do ensaio que sintetiza as ideias postas aqui e traz uma conclusão do próprio Bandeira:

\footnotetext{
A sua definição de poesia, no estudo sobre "Poesia e verso" contraria muitas observações do Itinerário, onde a atitude de humildade é responsável pelas declarações de ser poeta "quando Deus é servido", de que era "poeta menor" (Bandeira pensava assim por ser apenas lírico e não épico) (...). Mas essas declarações são continuamente negadas por uma série de exemplos que atestam o seu profundo conhecimento da arte poética. (...) Daí as várias definições que expõe, para chegar à conclusão de que "a poesia não existe em si; será uma relação entre o mundo interior do poeta, com a sua sensibilidade, a sua cultura, as suas vivências, e o mundo interior daquele que lê." (TELES, 1998, p. 113).
}

Nesse sentido, concordamos com Teles (1998) que afirma a consideração da figura do leitor em contato com a obra. Além disso, a partir da característica fundamental da simplicidade que esconde uma complexidade, o leitor é levado a fazer conexões e a preencher vazios de interpretação. Em vários momentos, percebe-se que a obra de Bandeira considera um leitor implícito, há no texto uma intenção comunicativa na relação entre o leitor, a obra e o autor.

A voz narrativa e lírica, como foi citado, parece querer se fazer humilde, menor, com palavras de todo dia, para se aproximar desse leitor, ao qual quer criar empatia. Empatia criada também pelo ritmo e tom de alguns poemas, que apresentam algo de alegre e luminoso, envolvendo o leitor, mas, como vimos na análise do poema "Vou-me embora para Pasárgada" feita por Wilson Flores (2015), mesmo esse tom pode trazer uma violência de fundo, violência historicamente presente na sociedade brasileira. 
Assim como os poemas, as crônicas também se caracterizam pelo estilo humilde. São muitas as abordagens sobre a ternura e a simplicidade com que Bandeira escrevia, como no comentário de Stefan Baciu sobre Bandeira cronista em Bandeira de Corpo Inteiro: "Ao correr dos anos, Bandeira escreveu sobre fatos, coisas e acontecimentos grandes ou pequenos com uma ternura que se igualou ao sentido critico com que sempre encara os acontecimentos." (BACIU, 1966, p. 79). Mas essa ternura e a humildade são efeitos poéticos construídos para alcançar o leitor e, assim, falar algo além.

$\mathrm{Na}$ linguagem simples, há objetos cotidianos, familiares ao leitor brasileiro, mas que também carregam forças contraditórias, significativas e complexas se formos olhar com mais atenção. O leitor, tanto de um discurso da voz bandeiriana quanto de um discurso cristão, através dessa simplicidade aparente, entra em contato com um todo complexo. O discurso poético construído por Bandeira possui imagens muito concretas, e íntimas, que orientam a leitura de um leitor a partir de uma forma que pretende concretizar o abstrato.

Tomando em consideração, ainda, o contexto brasileiro, e, segundo as características formuladas por Sérgio Buarque de Holanda em relação à cordialidade, é possível que a obra de Bandeira considere como leitor ideal um leitor brasileiro, cordial, buscando, aparentemente, um afastamento das grandes abstrações e uma preferência aquilo que é mais concreto?

Apesar do característico bacharelismo, da conhecida cultura como ornamento e o gosto pelo "enfeite gostoso" que se relaciona com a cordialidade, a poesia de Bandeira contrária a tal cultura, em certa medida, torna-se íntima do leitor com uma simplicidade que torna tudo mais concreto, o que destaca uma ambivalência e as contradições de uma cultura de ornamento. $\mathrm{O}$ "homem cordial” busca aproximar e familiarizar pessoas e objetos, apresentando uma negação às abstrações e uma aproximação ao que é emotivo e próximo. De acordo com Jerônimo Teixeira (2005), a incapacidade desse "homem cordial" para manter relações sociais baseadas na impessoalidade conduz, supostamente, a uma dificuldade de abstrações e um horror a distâncias.

Essas afirmações se relacionam com a discussão presente em Raízes do Brasil que mostra a falta de concordância de uma sociedade regida por princípios cordiais com o trabalho industrial, que carrega a perda de totalidade do trabalho manual e o desaparecimento de uma relação mais humanizada, assim como a importância à individualidade e as instituições com princípios abstratos. Há incompatibilidade também, de acordo com Jerônimo Teixeira (2005), da expansão emotiva do "homem cordial" com a poesia moderna, que possui como característica genéricas a incompreensão, a abstração e a dificuldade. 
O poeta maior seria o poeta das grandes abstrações, e Bandeira, ao se construir como menor, afirma não trazer essas abstrações, mas as pequenas alegrias e tristezas, próximas a qualquer um, conforme está em Itinerário de Pasárgada (destaca-se o desejo de aproximar o leitor), e, assim mesmo, traz algo mais complexo. Assim como acontece com as abstrações cristãs dos mistérios da fé, possíveis de ser comunicadas apenas com uma linguagem simples e com uma aproximação intima do cristão.

A morte, algo tão abstrato, pelo trabalho poético, torna-se familiar, apresentando-se, em Bandeira, como algo muito concreto. No poema "Consoada", por exemplo, como analisou Arrigucci (1990), é apresentada em seu caráter dicotômico (algo que se espera e que todos sabem que vem e conhecem, mas também algo desconhecido e inesperado) e, pelo tom simples e idílico no poema, há uma solução formal para o problema complexo de como lidar com a morte, sendo ela personificada como uma convidada para algo familiar e doméstico. Assim, através de uma personificação, ocorre essa familiarização, e, conforme Arrigucci (1990), é projetada como algo diferente de como é tida, pela sociedade burguesa da modernidade, ou seja, diferente de algo incerto e temível. Vejamos:

\section{Consoada}

Quando a Indesejada das gentes chegar

(Não sei se dura ou caroável)

Talvez eu tenha medo.

Talvez sorria, ou diga:

- Alô, iniludível!

O meu dia foi bom, pode a noite descer.

(A noite com os seus sortilégios.)

Encontrará lavrado o campo, a casa limpa,

A mesa posta,

Com cada coisa em seu lugar.

(BANDEIRA, 2009, p. 223)

O poema, suscitador de importantes questões pelo seu tom idílico na modernidade comentadas por Arrigucci (1990), não abandona o mistério que envolve a morte, reforçado pelos advérbios "talvez", pela conjunção “ou” e pela negação "não sei”, e ainda o verbo na forma subjuntiva ("tenha”) reforça o caráter de dúvida. Mesmo assim, a torna próxima tanto do eu-lírico como do leitor. O que é marcado pela mudança de tom duvidoso que ocorre nos cinco últimos versos, em que o modo verbal predominante não é mais o subjuntivo, e sim o indicativo. Assim, na fala com a morte, temos uma certeza simples, bucólica, que chega a ser suave, contrapondo com o adjetivo substantivado do primeiro verso ("Indesejada"), adjetivo pelo qual a morte é popularmente conhecida. Recursos assim intensificam a ternura construída para um 
objetivo estético, que aproxima até mesmo a morte. Como veremos neste trabalho, em alguns momentos na poesia de Bandeira, há a substituição de algo mais abstrato por algo muito familiar e, por vezes, muito infantil, já que a criança, com o apoio da família, torna tudo concreto, assim como a sociedade cordial apoiada nas famílias patriarcais.

A simplicidade que considera o leitor é, em vários momentos da fortuna crítica de Bandeira, colocada como aspecto importante. Ainda na obra de Arrigucci (1990), muitas vezes citada neste trabalho, há a análise de diferentes poemas e é explicitado como Bandeira considera esse leitor, além de vários recursos formais usados para isso, mas que são sutis e, por vezes, tênues, como veremos.

O crítico, também analisa o poema "Cantiga" e demonstra a leveza, a despretensão vinda da linguagem coloquial e da forma popular da redondilha, além da musicalidade, tudo isso dando a ver uma busca primeiro em cativar o leitor, em envolvê-lo. Assim,

esse grande artista moderno refinou no sentido de revelar o irrevelável, de dar a ver o que no fundo se concebeu, mas não se pode ver ou dar a ver enquanto tal, a não ser pelo paradoxo da forma de uma simplicidade natural, despojada de toda afetação do sublime, como ele próprio diria, "com a desconfiança evidente do sublime" que reconheceu nos modernistas brasileiros e procurou contornar, através da expressão cotidiana e da fala coloquial brasileira. (ARRIGUCCI, 1990, p. 167).

Somente através dessa forma simples e natural, que "Cantiga" se relaciona com a naturalidade e com o ritmo das ondas, o leitor é cativado e deixado com o enigma que é o poema. O que nesse poema e, em muitos outros, liga-se ao sentido da aceitação da morte, assim como em "Consoada", construindo, como falado, uma poética que apresenta uma morte muito concreta, sem transcendência.

Nessa perspectiva de criação de empatia com o leitor, uma questão central é a relação com a música, o que é importante também para a aproximação com o popular. Há, em "Cantiga", um aproveitamento da tradição popular ibero-brasileira - envolvendo a tradição da cantiga de amor, de amigo trazida com a colonização dos trópicos - com o uso da forma popular da cantiga, através da qual, de acordo com o estudioso citado, o subjetivo do poema se generaliza e a matéria particular tratada no poema torna-se dialeticamente universalizadora:

\section{Cantiga}

Nas ondas da praia

Nas ondas do mar

Quero ser feliz 
Quero me afogar.

Nas ondas da praia.

Quem vem me beijar?

Quero a estrela-d'alva

Rainha do mar

Quero ser feliz

Nas ondas do mar

Quero esquecer tudo

Quero descansar.

(BANDEIRA, 2009, p. 152)

$\mathrm{Na}$ leitura do poema, o ritmo, que se aproxima realmente de uma cantiga, media a experiência do leitor, que é levado naturalmente pelos movimentos das ondas do poema, fazendo dessa uma cantiga também sua. E faz, conforme Arrigucci (1990), um vínculo do humano e do natural das ondas do mar.

Assim, ainda considerando a análise desse crítico, vemos que a música popular brasileira dá uma característica hipnótica ao poema, como a música de macumba, na qual Bandeira parece ter buscado apoio, o que é confirmado, por exemplo, pela imagem construída através do verso "Rainha do mar". Além de trazer também, por meio do ritmo, o mito e os elementos da natureza aproximados ao subjetivo do eu-poético.

O elemento popular, então, aparece para trazer a característica de rainha do mar à estrela-d'alva, remetendo-nos à Iemanjá, uma das entidades mais populares, relacionada também com a tradição já que é aproximada a Afrodite. No poema, essa imagem “opera, pois, a passagem do céu e água, do alto e do baixo, do amor à morte (...) por via da tradição popular" (ARRIGUCCI, p. 189, 1990). Com um símbolo, com apropriações heterogêneas, há novamente a marca do subjetivo do poeta se generalizando.

O crítico aborda também pontos importantes para pensarmos a poesia de Bandeira que estão presentes em "Cantiga". Ele, ao comentar que a fala comum teve que sofrer uma profunda alteração, a serviço do metro, do ritmo e da repetição, para dar a impressão de simplicidade, mostra o poema como resultado de um trabalho (trabalho que considera o leitor), além de destacar ainda mais a dialética simplicidade e complexidade.

O poema, diante do exposto, constitui-se na dialética do nacional e do universal, tem um leitor brasileiro como um problema formal e envolve atitudes, como o aproveitamento do popular, historicamente identificadas e que se relacionam com o Modernismo. 


\subsubsection{A mitologia pessoal}

Outros críticos que comentam sobre a consideração do leitor em Bandeira são Gilda e Antonio Candido de Mello e Souza (2009), no prefácio feito para Estrela da Vida Inteira. Eles caracterizam a poesia de Bandeira como condensada e fraterna e destacam a atenção aos fatos essenciais, além da busca pela simplicidade quase popular, algo aprendido por Bandeira em sua poesia moderna.

Relacionam, então, essa consideração ao momento de maturidade de Bandeira e afirmam que, nas primeiras obras, os poemas tinham mais adornos coloridos e melodiosos, referindo-se aos poemas considerados mais parnasiano-simbolistas, como os que se encontram em Cinza das Horas, e era dispensado o impacto sobre o leitor. Para eles, esse impacto se encontra na concentração em torno dos dados essenciais em uma estrutura convincente, o que foi sendo desenvolvido e se destaca nos poemas de Libertinagem, como no já mencionado "Poema tirado de uma notícia de jornal" que possui um senso poético que apreende o essencial.

Ao se considerar esse leitor como problema formal, o que aqui se pretende, é interessante vê-lo como produto de uma aprendizagem e amadurecimento da obra de Bandeira, envolvendo também uma época determinada historicamente, a qual Bandeira faz parte.

Ainda sobre a busca em atrair o leitor, Gilda e Candido afirmam:

O caráter acolhedor do seu verso importa em atrair o leitor para essa despojada comunhão lírica no cotidiano e, depois de adquirida a sua confiança, em arrastá-lo para o mundo das mensagens oníricas. Poucos poetas terão sabido, como ele, aproximar-se do leitor, fornecendo-lhe um acervo tão amplo de informes pessoais desataviados, que entretanto não parecem bisbilhotice, mas fatos poeticamente expressivos. O seu feitiço consiste em legitimar a sua matéria -, que são as casas onde morou, o seu quarto, os seus pais (...)" (GILDA; CANDIDO, 1996, p. 11).

É com o uso de realidades poeticamente essenciais que a arte de Bandeira alcança um universo em que os elementos possuem expressividade máxima. Ao que Gilda e Candido (1996) acrescenta como importante uma fixação do poeta com espaços vividos e imaginados. $\mathrm{Na}$ perspectiva buscada aqui, esses espaços, assim como a repetição deles em vários poemas e crônicas, são primordiais.

Destaca-se, então, a mitologia íntima de Bandeira, comentada por vários críticos e também no próprio Itinerário, formada por amigos e familiares que frequentemente aparecem em sua poesia, como Ovalle, Irene, Totônio Rodrigues, ou ainda, Recife e o Rio de Janeiro, 
cidades que aparecem como personagens frequentes e significativos. A mitologia pessoal de Bandeira é pessoas e espaços ditos reais da vida de Manuel Bandeira e que estão como personagens em sua obra e ganham força simbólica como personagens mitológicos.

Esses espaços e essa mitologia são decisivos para a obra, que, citando mais uma vez Arigucci (1990), "soube incorporar [os espaços e a mitologia] não apenas a seu afeto de homem, mas à intimidade de seu universo poético.” (ARRIGUCCI, 1990, p. 50; grifo nosso).

É em relação a essa mitologia que a voz narrativa de Intinerário da Pasárgada significativamente aproxima Bandeira de poemas épicos - algo, até então, distante dos seus poemas líricos carregados pela caracterização de poeta menor:

Dos seis aos dez anos, nesses quatro anos de residência no Recife, com pequenos veraneios nos arredores, construiu-se a minha mitologia, e digo mitologia porque seus tipos, um Totônio Rodrigues, uma D. Aninha Viegas, a preta Tomásia, velha cozinheira da casa de eu avô Costa Ribeiro, têm para mim a mesma consistência heroica dos personagens dos poemas homéricos. A Rua da União, com os quatro quarteirões adjacentes limitados pelas ruas da Aurora, da Saudade, Formosa e Princesa Isabel, foi a minha Tróada; a casa de meu avô, a capital desse país fabuloso. (BANDEIRA, 2012, p. 29).

Esse trecho do Itinerário mostra a importância dessa mitologia, que se exibe parte de algo pessoal e íntimo, mas é acima de tudo poesia, ou seja, há o desejo de construir algo íntimo para produzir determinados efeitos poéticos ou legitimar a matéria poética.

A contradição da caracterização de "poeta menor" e a aproximação desse trecho a poemas épicos, ainda, desloca para a importância da vizinhança da casa do avô em Recife, lugar que é comparado à Tróada ${ }^{2}$ e que, em conjunto com a casa do avô e a cozinheira velha preta, recupera uma atmosfera patriarcal, presente no melancólico de versos de "Evocação do Recife", que trazem o avô morto, mas, mais do que isso, a perda dessa atmosfera em um movimento do geral e particular: "Recife.../ Rua da União.../ A casa do meu avô/ Nunca pensei que ela acabasse!/ Tudo lá parecia impregnado de eternidade". Ainda, nesses versos tudo é aproximado de algo mais particular, mais íntimo e, assim, mais concreto.

Também sobre essa mitologia, destaca-se o que Arrigucci (1990) comenta em relação a essa sensação que os personagens causam no leitor: um universo configurado, que se apresenta ao mesmo tempo familiar e acolhedor.

Explicita-se, então, a busca pelo íntimo em uma atitude cordial já que, como veremos, a intimidade é como um sintoma da noção de cordialidade. A intimidade desse universo poético, com esses seres com dimensões reais e ficcionais, configura algo individual, mas também

\footnotetext{
${ }^{2}$ Refere-se à cidade de Tróia, central nos poemas homéricos.
} 
acolhedor para o leitor que se aproxima e se familiariza pela simplicidade no tratamento desses seres. Mas, assim como o leitor, o próprio poeta se encontra envolvido, supõe-se "uma afinidade profunda entre o poeta e o aspecto da realidade próxima a que se liga.” (ARRIGUCCI, 1990, p. 52), confirmando algo fraterno entre autor e leitor, um laço afetivo, já que o que se diz é algo, ao menos em aparência, profundamente íntimo.

Portanto, além dos dados íntimos da vida do poeta, a repetição, em toda obra, dos personagens e dos lugares, reais ou imaginários, envolvem a busca pela familiarização do leitor de Bandeira que os reconhecem no conjunto da obra. Essa repetição também aproxima a poesia e a prosa do autor, as quais têm, assim, constantes referências entre elas.

Arrigucci (1990) comenta a força simbólica que personagens como Jayme Ovalle atinge no leitor, força que resulta de vários fatores da construção textual, citando, então, essa repetição à menção do nome em toda a obra, que traz conotações e associações. Esse personagem, por exemplo, aparece no poema "Poema só para Jayme Ovalle", nas crônicas "Ovalle", "O místico", entre outros textos.

Essa repetição de Ovalle merece atenção. Esse compositor e poeta brasileiro faz parte da mitologia intima criada pela obra bandeiriana, é amigo de Manuel Bandeira e se torna um símbolo poético. É importante destacar que o que importa aqui não é o Jayme Ovalle real, mas o personagem trabalhado poeticamente. Ainda assim, é interessante notar a informação que Victor Heringer (2012) considera em seu artigo “O Jayme Ovalle de Manuel Bandeira”, já que vemos uma personalidade tendente ao relacionamento social cordial, principalmente no que diz respeito à confusão entre o público e o privado:

Jayme Ovalle possuía duas certidões de nascimento, uma indicando que nasceu em 6 de agosto de 1894, em Belém do Pará, e outra que dava o Rio de Janeiro como cidade natal e o 5 de agosto de 1892 como data de nascimento. O segundo documento fora forjado para que Ovalle pudesse regularizar seu registro na Imprensa Nacional, onde trabalhava desde 1911. À época da nomeação (por recomendação do senador Artur de Souza Lemos), Ovalle contava apenas 17 anos, o que o impediria de assumir um cargo público. Desse ato de malandragem simbolicamente fundador, nascem os dois Ovalles: o funcionário público exemplar, pessoa historicamente palpável, e um outro Ovalle, forjado em grande medida pelo próprio, mas também, e principalmente, pelos que conviveram com ele. (...) Ovalle era brasileiro, de estado nenhum e de todos os estados; era capaz, portanto, de driblar a lei em benefício próprio e de se aproveitar da promiscuidade entre o público e o privado - mais tarde, apadrinhado pelo presidente da República, o marechal Hermes da Fonseca (cujo filho era casado com a irmã de Jayme), Ovalle prestaria concurso para o Ministério da Fazenda, concurso este "realizado em condições cômicas, em que ele deveria ser aprovado de qualquer maneira", segundo Augusto Frederico Schmidt. (HERINGER, 2012, p. 40). 
É possível ver que Jaime Ovalle, além de fazer parte da mitologia particular do poeta, algo bastante cordial, também aparece como um "homem cordial", com características que também envolvem o tipo de leitor implícito considerado na obra em questão.

Na crônica "O Místico", por exemplo, responde com diminutivos e com ternura cativante a uma ligação por engano: "Não, aqui é minha casinha...”, ternura reforçada pela voz narrativa: "a última manhã do místico na casinha da ladeira foi uma coisa tão comovente (...)". O personagem carrega uma dimensão mítica e imaginativa, mas não como um ser distante, e sim próximo e familiar, há o tom afetivo e emotivo.

Além disso, Ovalle, como força simbólica, fala do modernismo. É sabido que ele está presente na obra de outros escritores da época, como Drummond. Ao pensar o período de um contexto de produção, é perceptível autores que dialogam.

\subsubsection{Bandeira e Drummond: diálogos cordiais}

É interessante refletir sobre alguns diálogos possíveis entre Drummond e Bandeira, não desconsiderando as diferenças profundas entre as obras dos dois poetas. Algo nesse sentido foi citado ao refletirmos sobre o cotidiano moderno tomando como base a análise crítica de Wilson Flores (2012), colocando os dois poetas em um contexto de produção específico.

Sylvia Tamie Anan (2006) considera como importante o fato dos dois poetas e cronistas terem passado pela experiência de migrante na metrópole, o que vai ser significativos nas crônicas produzidas por eles. Além disso, para ela, eles constroem símbolos para o indivíduo que vive deslocado no meio urbano, como é o cacto de Manuel Bandeira, e a flor de Drummond. $\mathrm{Na}$ verdade, de forma bem diferente, esses símbolos podem expressar contradições do Brasil em processo de modernização.

Jerônimo Teixeira (2005) na obra Drummond Cordial, que vai ser retomada no capítulo 2 deste trabalho com o acréscimo de aspectos importantes ao que se busca analisar aqui, também mostra contatos entre os dois poetas. Nesse estudo crítico, Jerônimo (2005) analisa como a obra de Carlos Drummond sugere a cordialidade e, a partir disso, remete um ponto de contato com a poesia de Manuel Bandeira:

Vários problemas de Drummond escaparão, evidentemente, desse teorema histórico que estou tentando montar a partir de Raízes do Brasil. Acredito, porém, que a cordialidade é um dos problemas centrais da poesia drummondiana. Talvez não só dela: "Vou-me embora pra Pasárgada", de Manuel Bandeira, poema obrigatório de toda antologia modernista, traz um 
verso que bem poderia ser o moto do "homem cordial": "Lá sou amigo do rei" (TEIXEIRA, 2005, p. 45).

Esse problema, parte do contexto brasileiro moderno, está na poesia drummondiana e na bandeiriana, com suas diferenças fundamentais. Se em Drummond, já se apresenta um limite para a cordialidade e não há ilusão na volta de um passado, Bandeira, nas palavras de Teixeira, "insiste em fixar formas históricas evanescentes, aqueles tipos que até mesmo na cidade suscitam certa atmosfera provinciana e primeva - o vendedor dos "Balõezinhos" ou os “Camelôs”, por exemplo.” (TEIXEIRA, 2005, p. 45). Pode-se notar tal atmosfera provinciana e primeva, mas como algo constitutivo do moderno, como um passado que não deixa de atuar e que é atualizado pela modernização de forma a manter a desigualdade, e, assim, salários rebaixados etc, o que se liga ao subemprego de tipos cotidianos das feiras e das ruas do Brasil costurado nesses poemas.

O crítico dummondiano fundamenta a questão da cordialidade com o poema "Momento num café”, em que, apenas um homem não age da forma polida e automática diante de um enterro. Comum em outros momentos de Bandeira, Teixeira (2005) comenta da inversão da ideia cristã tradicional sobre alma e matéria, mas afirma que, mesmo assim, há os valores tradicionais na voz lírica de Bandeira, já que o homem em destaque no poema age tal como um "homem cordial" por se distanciar da polidez automática dos outros homens.

O que de fato há nesses poetas é a dialética de um mundo tradicional patriarcal, muito mais decadente em Drummond do que em Bandeira, e da vida em modernização, urbanizada e mecanizada. Há uma história de permanência do mundo patriarcal no poeta moderno, o que se aproxima do "homem cordial", agora sob um viés de negatividade.

Tudo isso está sugerido em "Balãozinhos", em "Camelôs", em "Momento num café" e em muitos poemas de Bandeira, assim como está em crônicas com uma forte permanência do passado na modernidade, já que muitas criticam modernizações de arquiteturas que marcam o passado colonial, como veremos.

Para exemplificar, atentemo-nos brevemente a alguns versos desses poemas citados. No poema "Camelôs", de Libertinagem, já o título anuncia falar de um trabalhador informal que invade as ruas das cidades, no entanto, os brinquedos enumerados na primeira estrofe com ausência de pontuação são brinquedinhos, marcados no diminutivo em sua maioria, que conferem uma atmosfera provinciana, além de um tom afetivo e o baixo valor econômico dos brinquedos: "O que vende balõezinhos de cor/ $\mathrm{O}$ macaquinho que trepa no coqueiro/ $\mathrm{O}$ cachorrinho que bate com o rabo (...)" (BANDEIRA, 2009, p. 127). 
A voz lírica sugere contrapontos, por exemplo no interior dos versos " $\mathrm{E}$ ensinam no tumulto das ruas os mitos heroicos da meninice..." e "E dão aos homens que passam preocupados ou tristes uma lição de infância", da cidade moderna (tumulto das ruas, homens preocupados) e da infância, ressaltando com uma afetividade construída em torno dessa infância em uma oposição homem e criança.

"Balõezinhos", de Ritmo Dissoluto, livro publicado em 1924, anterior à Libertinagem, gira em torno dos balõezinhos de cor, um dos brinquedos representando em "Camêlos". Como vimos, a partir da análise de Wilson Flores (2012), no poema "Balõezinhos", também há contrapontos da mercadoria infantil ao cotidiano preso a necessidades, e há um movimento do desejo e do espanto, relacionadas às frustações relacionadas à pobreza ("E em torno do homem loquaz os menininhos pobres fazem um círculo inamovível de desejo e espanto"). Nesse poema, também é representado o trabalho informal (“o vendedor infatigável”) e os meninos pobres ganham destaque ("em redor dele há um ajuntamento de menininhos pobres").

Nos dois poemas, o que se encontra são elementos contrastantes que não permitem uma leitura conciliatória, como foi afirmado por Flores (2012) em relação a "Balõezinhos". Nos dois, apesar de uma leitura conciliatória apenas aparente, há formas precárias de trabalho, contradições de classes que representam bem o cotidiano de um país marcado por uma modernização desigual como no Brasil e, ainda, a insistência de um passado, mesmo que não explícito, que não se concilia bem com o cotidiano da cidade moderna.

Como comentado, o emprego de diminutivos ganha importância nesses poemas, pela repetição, pela ternura construída para aproximar um leitor, pela ironia e, ainda, acompanhando uma nota existente em Raízes do Brasil, é uma forma sintática que apresentaria sobretudo um traço mais da fala rural, e:

No Brasil, onde esse traço persiste, mesmo nos meios mais fortemente atingidos pela urbanização progressiva, sua presença pode denotar uma lembrança e um survival, entre tantos outros, dos estilos de convivência humana plasmados pelo ambiente rural e patriarcal, cuja a marca o cosmopolitismo dos nossos dias ainda não conseguiu apagar. Pode-se dizer que é um traço nítido da atitude "cordial" indiferente ou, de algum modo, oposta às regras chamadas, e não por acaso, de civilidade e urbanidade. (HOLANDA, 1963, p. 139).

$\mathrm{Na}$ totalidade dos poemas, esse aspecto cordial se combina com os outros aspectos contraditórios citados. Assim também a cordialidade persiste em um "Momento num café", de Estrela da Manhã, livro posterior à Libertinagem, pois um "homem cordial", como foi 
percebido por Jerônimo Teixeira (2005), "se descobriu num gesto largo e demorado/ Olhando o esquife longamente", um gesto contrário ao cotidiano capitalista.

A discussão da cordialidade, viva em Bandeira, está também no poema "Retrato de família" de Drummond de uma outra forma, com retratos patriarcais e com o passado permanecendo como um fantasma. Mas, como comenta Teixeira (2005), há um fracasso da tentativa própria dos retratos de se perpetuar ("Este retrato de família/ está um tanto empoeirado"), há perda do dinheiro (“Já não se vê no rosto do pai/ quanto dinheiro ele ganhou”), das viagens ("nas mãos dos tios não se percebem/ as viagens que ambos fizeram”) e das memórias da monarquia (“A avó ficou lisa, amarela, sem memórias da monarquia”), além da perda dos laços cordiais do eu-lírico ("Esses estranhos assentados,/ meus parentes? Não acredito.”). Há a dialética da permanência e da transformação do passado brasileiro e, mesmo que em negativo e irritada, há a presença da cordialidade.

Os dois poetas, apesar de fazerem parte de uma renovação dos recursos formais tradicionais, iniciada pela primeira geração modernista - tais como frases curtas, verso livre, temas do cotidiano -, reencontram-se com o Brasil patriarcal, mostrando que essa história não foi superada na sociedade brasileira.

Além disso, como foi bastante sublinhado por Jerônimo Teixeira ao analisar a poética de Drummond, "o "homem cordial" só consegue fazer-se poeta social cantando a família." (TEIXEIRA, 2005, p. 12), o que fica claro, mesmo que em uma perspectiva bem diferente de Drummond, na mitologia pessoal de Bandeira e em seu apego aos familiares e amigos da infância, sendo representados também com uma certa saudade desse passado (outra característica, o saudosismo, da cultura luso-brasileira que envolve o nosso "homem cordial"), como comprova o verso de "Evocação do Recife": "Como eram lindos os nomes das ruas da minha infância”, entre outros que serão melhor discutidos no Capítulo 3 desta dissertação.

O eu-lírico de Bandeira apresenta a sua voz com um descontentamento com a modernidade, mas que não é simples, configura-se na contradição da sociedade brasileira e sugere um apego a valores do passado, com a persistência do patriarcalismo, estando presente a dialética modernidade e tradição. Vários caminhos de como Bandeira trata esteticamente essas questões são comentados pela crítica, muitas vezes há uma relação com o passado mediada pela infância, além da citada insistência de um tom provinciano.

"Evocação do Recife" é exemplo de um poema que ilustra esses aspectos. Como comentado, nele, há a presença da mitologia íntima (A Rua da União, Aninha Viegas, Totônio Rodrigues, Rua da Saudade, a casa do avô etc), que, em conjunto com o tom de recordação do poema (visualizado, por exemplo, no verso "Cheia! As cheias! Barro boi morto árvores 
destroços redemoinho sumiu"), recupera e projeta poeticamente uma infância. Fala-se, a partir disso e de muitos outros aspectos que serão aprofundados sobre esse poema no capítulo 3, de Recife, região do Brasil que, mesmo na modernidade, é marca de tradições.

\subsubsection{A mediação da infância e o passado que se faz presente}

O uso de situações biográficas da infância, como em "Evocação do Recife", é algo central na obra aqui estudada, na qual a relação com o passado se faz essencial, importante para pensar o nacionalismo, além dessa voz socialmente localizada.

$\mathrm{Na}$ prosa do Itinerário, comenta-se o conteúdo de emoção que as recordações da infância têm, sendo identificadas com as emoções artísticas. É também citado o contato com a garotada do Morro do Curvelo que remetia Bandeira à infância na Rua da União em Pernambuco. Esses elementos da infância, os quais também devem ser problematizados, estão constantemente presentes em outras obras em prosa e na lírica.

Aqueles personagens e lugares, referenciados em toda obra e que criam uma intimidade com o leitor, além de serem íntimos ao próprio sujeito, muitas vezes têm relação com a infância, com lembranças que contém fatos factuais, mas também muito de imaginação, de ficcional.

As crônicas bandeirianas trazem, assim como toda a sua obra, elementos autobiográficos, impressões do cronista sobre arte, arquitetura, a infância dos meninos pobres do morro do Curvelo, onde Bandeira morou entre 1920 e 1933, além disso, as aparentemente íntimas memórias da sua infância, algumas vezes, também se fazem presente. Sylvia Tamie Anan (2006), em tese já citada neste trabalho, afirma que, sendo a crônica um gênero voltado para o presente e para a vida pública, essas memórias demoram a surgir nesse espaço, e considera que foi Bandeira que introduziu essa temática na crônica brasileira.

Para ela, é importante destacar as crônicas banderianas como textos propriamente literários com um lirismo presente. Nas crônicas que tratam da memória da infância, há um maior grau de lirismo, além disso, considerando as características de texto jornalístico, a recuperação do passado é feita de forma intima com o presente, explicitando, nas palavras de Anan, "uma série de contradições entre o sujeito e o meio em que ele se encontra" (ANAN, 2006, p. 17). Ou seja, o tratamento com a infância dá a ver contradições que envolvem o presente e o passado, permitindo uma visão do presente.

Nessa tese, que busca analisar a crônica bandeiriana com um olhar para a infância, destaca-se a que acontece no momento presente do escritor, ou seja, aquela vista da janela de Bandeira morador do Curvelo. São várias as crônicas que relatam garotinhos pobres daquela 
rua, como a crônica "Lenine". Nelas, o outro vai aparecendo e, nesse contato, é nítida uma recordação e um saudosismo da infância subjetiva. O cronista contrapõe a vida adulta à infância, preferindo a última.

Anan também associa sabiamente essa infância a um estado provinciano do Brasil:

É possível comparar a infância dos meninos ao um estado "provinciano" do Brasil, a que o cronista refere-se constantemente, em que a lei e as relações humanas se realizam ainda de forma ingênua e autêntica. Assim, Lenine representa a própria vida do Curvelo, inocente no sentido de apolítica, que se identifica com essa vida de província tão aproximada por Bandeira e "estragada" pela política. (ANAN, 2006, p. 50).

Além disso, a tese de Sylvia Anan (2006) problematiza os "servicinhos" que são prestados pelos meninos a Bandeira. O processo de modernização é problematizado com uma pobreza, que aparece discretamente, através desses servicinhos ou a não alusão à vida escolar, como percebe a crítica, que cita também as crônicas que Bandeira encontra os meninos adultos e todos exercem trabalhos manuais, aproximados de uma classe social mais baixa, significativo ainda é o destaque dado ao fato de não serem marginalizados, sendo esse o destino esperado na lógica da cidade moderna que mantém intacta prerrogativas, privilégios e a desigualdade reinante que envolve a marginalização.

Pensando na voz narrativa com apoio na análise de Anan (2006), observa-se que essas narrações, em algumas crônicas, de episódios no morro do Curvelo com crianças, com espirito de brincadeira, são divertidas ao leitor. É interessante perceber um carinho, uma ternura do cronista com essas crianças a partir desses episódios.

Assim, tanto na prosa como na poesia, elementos da infância são importantes mediadores e levam a cargas significativas profundas. Podem, inclusive, estabelecer diferenças entre esses dois gêneros. Arrigucci (1990) comenta, por exemplo, do Boi Morto, um elemento da infância que é recorrente, e cita que, na crônica “Cheias, cheias...", esse boi está no discurso narrativo articulado com outros elementos da sua memória relacionada a uma experiência subjetiva de um acontecimento especifico. Já nos versos de "Boi Morto", esse elemento é significamente distinto, abrindo-se para uma outra significação simbólica, já que, diferente da crônica, ele está em destaque.

Como símbolo, é um elemento da experiência pessoal que atua para uma revelação, o que, para explicar, o crítico retoma que, na tradição literária clássica, os poetas usavam de certas imagens, para um reconhecimento e súbita revelação. Enquanto, muitas vezes, isso é parte de 
uma experiência coletiva e retirado de uma tradição, em Bandeira e em outros poetas, parte-se também do individual e revelam algo do sujeito que dá a voz ao poema.

Assim como em outros poemas analisados pelo crítico, ele afirma que, em "Boi morto", há a construção de uma cena e, a partir dela, é possível ao sujeito ver a si mesmo em uma circunstância. A cena se assemelha à prosa e, a partir da comparação com a conjunção "como" da infância do poeta com uma situação presente, há uma presentificação daquela situação do passado, aspecto também importante: "como em turvas águas de enchente,/ me sinto a meio submergido/ entre destroços do presente".

Além disso, a forma de construção dos versos e o estribilho levam à sensação de tudo sendo arrastado à destruição, assim como o Boi morto, o que se dá também pelo movimento alcançado pelo ritmo, segundo Arrigucci (1990), realçado primeiro pelos elementos contrastantes, em conjunto com a divisão rítmica de pequenos segmentos integrados a uma unidade do movimento avassalador, utilizando-se de versos octossílabos com acentuação rítmica que colocam em destaque palavras importantes.

Importante também é a oposição recorrente do /ô/ fechado (boi morto) e do /a/ aberto (alma), esses e outros recursos são percebidos pelo crítico e vão permitindo sugestões de sentido em cada verso e no todo do poema. Assim, a partir do boi morto, há um "sujeito dividido e submerso no fluxo das águas e do tempo" (ARRIGUCCI, 1990, p. 243), ele faz parte do todo, ao ver o boi morto, o sujeito vê a si mesmo sob ameaça de destruição.

Arrigucci (1990), ao perceber um realismo extremo, através da construção metafórica de um mundo exagerado, mas que é ligado a uma realidade interna, apresenta Bandeira como partícipe de toda uma tradição da poesia moderna, que tem seu marco em Baudelaire, fazendo uma aproximação do poema "Boi morto" ao "Une charogne", já que é possível ver nos dois poemas, um tema do interior humano visto através de algo inferior como uma carcaça, ou seja, o crítico tenta demostrar que Bandeira, ainda que inserido em um contexto diferente - o brasileiro, acompanha uma tradição de formas de tratamento da modernidade:

Digamos que a recorrência interna na obra individual de um motivo como esse repercute ainda como efeito de um quadro temático expressivo que é produto de uma tendência histórica da época, índice do processo de modernização a que decerto não ficou imune o poeta brasileiro, apesar das diferenças específicas que soube imprimir em sua obra. (ARRIGUCCI, 1990, p. 251).

Partindo de tudo isso e de outros aspectos, o crítico mostra que o grotesco, presente no boi morto, na natureza estranhada, situa o sujeito com uma atitude diante da morte, tema também importantíssimo a Bandeira. Apoiando-se nessa análise crítica, percebemos como uma 
imagem recuperada da infância mostra uma relação com a morte, de terror, diferente de outros poemas.

Há, ainda, destaque para o Brasil ali presente, já que o crítico analisa também que o boi faz parte do aspecto socioeconômico, sendo instrumento de trabalho no campo, e do imaginário cultural do Nordeste. Mas contra argumenta que isso só importa como aproveitamento de algo baixo, perto do povo, que, paradoxalmente, fala de algo sério do próprio sujeito, no caso, a morte tida como espantosa e estando presente o aprender a morrer. Ele ainda destaca a problematização da fragmentação do sujeito, comum à modernidade, problematização que acontece com a fragmentação do boi morto.

A questão que Arrigucci (1990) propõe é fundamental, pois nos mostra como a arte de Bandeira chega à dimensão ontológica, usando de vários meios significativos para as construções de sentido, explicitando o subjetivo, o particular e o universal. Tudo isso partindo de um elemento da infância, mas que é transfigurado no poema.

Esse crítico analisa outros poemas em que a infância é significativa, como em "Profundamente", no qual a morte também se faz profundamente presente. Arrigucci (1990) faz considerações nessa análise que se tornam importantes neste trabalho.

Ele destaca, a partir das emoções da infância, a presença do passado regional brasileiro, e sintetiza o que é o nacionalismo presente em muitos poemas de Bandeira, principalmente os escritos a partir do final da década de 20: articulação da matéria pessoal, que também é histórica, da realidade brasileira e da intenção modernista de descoberta de uma consciência dessa realidade, o que, no poema citado, é exemplificado pela imagem da festa de São João da infância do eu-poético em uma região tão tradicional do Brasil, ligando, então, subjetividade e coletividade.

Nesse poema, como Arrigucci (1990) demonstrou com a imagem sonora do trem de ferro cortando o silêncio do final da festa tradicional, há o contraste do tempo da modernidade com a morte de um mundo em que o sujeito se identifica e que pensou que não acabasse: “ (...) Apenas de vez em quando/ O ruído de um bonde/ Cortava o silêncio/ Como um túnel./ Onde estavam os que há pouco/ Dançavam/ Cantavam/ E riam/ Ao pé das fogueiras acessas?”

Assim como em "Evocação do Recife", há a imagem da casa do vô, uma atmosfera patriarcal que Bandeira faz parte e não quer que acabe. O que podemos observar, por exemplo, nos versos que citam os personagens da infância que insistem em se fazer presente, mesmo que na ausência e em negativo: "Hoje não ouço mais as vozes daquele tempo/ Minha avó/ Meu avô/ Totônio Rodrigues/ Tomásia/ Rosa/ Onde estão todos eles?" 
Percebemos, assim, que essa utilização da infância é muito mais que uma saudade, ou uma preferência dela em relação à vida adulta, e suscita várias questões. Como destaca o crítico, não é um passado morto idealizado, mas algo passado que não deixou de atuar, uma lembrança viva que pode se atualizar e se tornar uma percepção de mundo. Esse passado pode trazer emoções e questões nem sempre conscientes, mas que estão ali presentes.

Há uma questão formal fundamental presente na análise de "Profundamente" que foi citada também ao se comentar sobre o poema "Boi morto": uma presentificação do tempo passado. Em "Profundamente", a construção acontece de tal forma que o sujeito se reencontra, solitário, consigo mesmo a partir do passado distante. Um passado próximo, um passado remoto e o presente são colocados em paralelo, o que traz o tempo da infância para o presente do sujeito. Algo reforçado por um estribilho recorrente que parece eternizar um presente intemporal.

Yudith Rosenbaum (1993), no estudo intitulado Manuel Bandeira: uma poesia da ausência, também vê que, sendo constantemente presente, a infância pode suscitar uma série de questões. Para ela, "abordar o topos da infância na poesia de Bandeira implica, antes de tudo, depreender seu significado a partir de uma necessidade subjetiva de reconquistar tempo e espaço passados" (ROSENBAUM, 1993, p. 41).

Rosenbaum (1993) percebe a infância como um paraíso perdido e um fenômeno iluminado, algo que se configura como ausência, que marca os anos felizes do poeta antes da doença, e que retorna com evocação poética. Ela se ocupa da infância em relação a uma perda consciente dela por um sujeito, um conflito que encontra na própria lírica o consolo da inquietação. Aqui, consideramos que, além disso, a constante volta à infância marca uma voz determinada socialmente e, como algo subjetivo e particular, diz muito sobre o geral e a nação.

Concordando com ela, vemos que o apelo à volta de uma infância é movido pela falta, por um desejo de trazer cenas e personagens novamente. E, com isso, Bandeira se expõe ao leitor abrindo sua identidade, ou seja, criando uma intimidade, na qual um passado que a voz lírica quer fixar se faz importante.

Essa estudiosa também observa a presentificação do passado, analisando, por exemplo, que o poema "Elegia de verão", de Opus 10, remete que acontece uma ilusão de contemporaneidade - nesse poema, isso é alcançado através das aliterações /v/ (vãs, mudaves, mudáveis, aves - relacionada a uma colagem irônica do soneto de Sá Miranda), que criam uma igualdade sonora e abole uma perspectiva temporal, reorganiza espaços vividos, assim como em "Profundamente".

Assim, os versos “O sol é grande. Ó coisas/ Todas vãs, todas mudaves!/ (Como esse “mudaves", Que hoje é “mudáveis"/ E já não rima com “aves”.)" estão em uma estrofe que, 
além da aliteração e da colagem, tem-se um comentário, entre parênteses, sobre o tempo presente do poema e, assim, sobre a própria atividade poética como o espaço para reconquistar o que passou. A ilusão de contemporaneidade, e a evocação do passado, efetiva-se pela construção que possibilita a rima comentada de forma metalinguística no poema, o qual também tem como temática a mutabilidade do tempo e o passado.

Em "Profundamente", os espaços temporais também são reorganizados pelo trabalho poético, o passado torna-se presentificado no espaço do poema, como bem notou Arrigguci (1990). O verso "Quando ontem adormeci" introduz uma ideia temporal e a montagem das imagens que vão ser desenroladas coloca uma mistura de tempos, tais como exemplificam os versos seguintes, apresentados no poema com a formação de imagens plásticas e com a presença de várias palavras referenciando o tempo (quando, ontem, hoje) : “Quando ontem adormeci(...) / Havia alegria e rumor / Vozes cantigas e risos/ Ao pé das fogueiras acesas.", "Quando eu tinha seis anos/ Não pude ver o fim da festa de São João" e, ainda, "Hoje não ouço mais as vozes daquele tempo." .

Rosenbaum (1993) analisa também o poema "Infância", de Belo Belo, obra publicada em 1948, ou seja, já na maturidade do poeta. Verificamos que procedimentos estilísticos, como a pontuação, fazem a leitura ser rápida, o que acompanha a sensação de recordações às vezes inconclusas na memória: “Ainda em Petrópolis... um pátio de hotel... brinquedos pelo chão...” (BANDEIRA, 2009, p. 208).

Destaca-se, novamente, as presentificações, sendo que, para isso, a narração é marcada com uma atemporalidade e, diferentemente dessa noção temporal, os espaços são bem demarcados. Através desses aspectos, há, no poema, uma infância, com aprendizagens, lugares, pessoas essenciais (as palavras também são essenciais, há poucos verbos, dispensando as ações), e o leitor é chamado, intimamente, a entrar nessas recordações.

Realmente, aparece, para esse leitor que é quase um amigo, apenas o que é essencial ao sujeito que presentifica um passado. E, assim, fala também, de forma metalinguística, da própria obra bandeiriana madura que usa palavras fundamentais e simples para expressar o essencial.

Faz-se essencial no poema a teta negra da ama-de-leite que ele desejava recordar ("quem me dera recordar a teta negra de minh'ama de leite"), assim como os "brinquedos pelo chão" seguidos de reticências. Há, novamente, toda uma recuperação de alguém servindo esse sujeito, o que se articula com a saudade de um mundo patriarcal comentada neste trabalho.

Rosenbaum (1993) cita o contraste entre o branco e o preto (negra e leite), comentando também não só a inocência da amamentação em relação à teta da negra que ele quer recordar em um presente, mas um erotismo facilmente identificado. $\mathrm{O}$ que recupera um outro aspecto 
das famílias patriarcais citadas, a sexualidade do menino com a serviçal negra, também presente na cena formada pela oposição de cores. O mundo patriarcal e escravocrata ressurge no espaço literário em 1948 e sempre persiste na sociedade brasileira.

Atenta a um aspecto psicológico, a crítica citada analisa a poesia de Bandeira em sua tensão da ausência com a presença, dando destaque a uma melancolia, e mostra a lírica revelando ou apaziguando inquietações, já que, "ao figurar o ausente, o que foi perdido ressurge no espaço literário" (ROSENBAUM, 1993, p. 81). Assim, ela aproxima a produção poética a uma reorganização totalizadora de lembranças fragmentadas, sendo invertidas de novas significações. O que é significativo ao pensar a infância e o passado na obra, além dos personagens atingidos pela morte e os lugares atingidos pela modernização de forma melancólica.

A melancolia, muitas vezes apresentada de forma dialética com o humor, está como uma tendência que percorre a obra e como força criadora. Essa dialética, como vimos, foi analisada por Mara Ferreira Jardim (2007) como aspecto definidor de um caráter nacional que está como problema formal na obra de Bandeira.

Rosenbaum (1993) a relaciona a uma tentativa de preencher as ausências por meio da linguagem, o que marca também um saudosismo que explica a recorrência de evocações e recordações, e, assim, a presença forte das memórias da infância, visto aqui não só como algo subjetivo, mas que atinge o geral e o nacional.

Essa questão aparece muitas vezes relacionadas a cidades brasileiras transformadas pela modernidade, com as quais a voz lírica apresenta essa relação de saudosismo. Bandeira como poeta consequente em pleno processo de modernização olha de forma crítica a modernidade, mas a complexidade e a ambiguidade que se encontra nos poemas traz mais, ao que Rosenbaum (1993) sintetiza de forma coerente ao falar que "há mais do que rejeição ao progresso; há perda de um lugar simbólico onde o sujeito se reconhecia.” (ROSENBAUM, 1993, p. 145), mesmo tendo Bandeira vivido pouco tempo da infância em Recife, é simbólico, ao que cita a revolta do poeta com a perda do Recife da infância ("Diabo leve quem pôs bonita a minha terra").

Nesses lugares ausentes em decorrência das transformações e da mutabilidade dos tempos, há muito de um Brasil patriarcal e rural em sua complexidade e contradições, como vimos na análise do lugar simbólico de Pasárgada.

\subsubsection{A província}


Na poética de Bandeira, há uma revelação da dialética da perda e da permanência desses lugares simbólicos, não só com as cidades, que o eu-poética de Bandeira quer que permaneçam provincianas, mas com as pessoas, os costumes e tradições, a casa do avô e as brincadeiras da infância, que revelam muito mais que um saudosismo do tempo de criança, fazendo com que o mundo patriarcal seja revivido e buscado no espaço literário. O passado, como vimos, frequentemente se faz presente, a partir, por exemplo, da ambivalência entre tempos verbais presente e pretérito nos poemas e, assim, de uma atualização do ausente pela força da memória.

Há muitos exemplos nesse sentido em poemas e crônicas de Bandeira. Na obra Crônicas da província do Brasil, há, em várias crônicas, críticas à nova arquitetura de cidades, como Recife em Ouro Preto, que envolve o início da ideia de patrimônio histórico e da necessidade de sua preservação.

Há também a valorização do provinciano (até no título da obra) já citada, com crônicas principalmente do interior do país. Sylvia Tamie Anan comenta que "mesmo não escrevendo sobre ou para a província, o cronista a mantém sempre em mente, principalmente nas crônicas sobre a cidade do Rio de Janeiro" (ANAN, 2006, p. 54). O que nos remete à afirmação já comentada de Jerônimo Teixeira sobre a poesia de Bandeira, a qual, mesmo na cidade, insiste em fixar formas provincianas.

Ela destaca a grande frequência que os termos província e provinciano aparece nas crônicas com diferentes tons. Como vimos, nas advertências dos livros de crônica, Bandeira se aproxima de algo provinciano, mesmo morando na época na capital Rio de Janeiro, colocandose em oposição à agitação do meio urbano.

Associa esses termos, ainda, a Gilberto Freyre, já que duas crônicas que o mencionam tem essa relação ("Sou provinciano" e "Pernambucano, sim senhor"). Além de trazer a discussão sobre a arquitetura do Recife, que, para alguns, deveria ser adaptada por questões de higiene, e, para outros, deveria permanecer tal como nas recordações da infância e como o tempo demarcado pelo passado colonial. Essa segunda opinião, para Sylvia, tratava-se de uma antiga elite que preservava as marcas do seu período áureo, sendo criado um imaginário mítico em torno do Recife, que envolvia obras como Casa Grande \& Senzala de Gilberto Freyre. Manuel Bandeira, embora não fosse filho dessa antiga elite, relaciona-se com essa discussão.

Em torno de todo esse contexto, é significativo também a influência da infância para o cronista de acordo com a perspectiva de Sylvia. Ela remete, na crônica citada, a atenção voltada para o que ele não viu quando era menino ("era de preferência para Olinda que se voltava a minha curiosidade, cujo oitero nunca subi em menino"). Concordando com a estudiosa, é 
significativo que os aspectos citados mostram uma visão do passado não apenas de Bandeira, mas de um grupo.

Além dessas considerações, o estudo desenvolvido por Sylvia nos coloca a atenção para duas cidades em especial: Rio de Janeiro e Recife, embora muitas outras cidades apareçam. As duas são pertencentes do imaginário da infância, sendo que o Rio de Janeiro é a cidade em que o poeta morou da infância até o fim da vida, acompanhando um processo de modernização. Já Recife foi a cidade em que Bandeira nasceu, viveu pouco tempo da infância e só viu em viagens depois, e, sobre ela, a voz nos poemas e nas crônicas critica as modernizações que foram acontecendo, a idealizando como uma cidade parada no tempo. Assim, há a construção de uma terceira cidade:

\footnotetext{
Impedido em seu sonho de remodelar, à sua maneira, as duas capitais da infância. Bandeira acaba construindo uma terceira cidade, "intacta, suspensa no ar", diferente daquele que encontrou em sua vida adulta, mas que talvez também não corresponda exatamente à que conheceu na infância, e sim mais provavelmente uma cidade que "podia ter sido e não foi". (ANAN, 2006, p. 13).
}

Percebe-se que Bandeira, em uma tentativa de resgatar esse passado da infância, cria um outro Recife, em oposição às mudanças naquilo que ele não quer que mude.

Nos poemas "Profundamente" ou "Evocação do Recife", por exemplo, aparece esse espaço especifico. Arrigucci identifica Recife como um mundo mágico, mostrando como esse espaço na época da infância é idealizado e exaltado pelo poeta: “(...) Em Recife - um mundo mágico, formado por outras ruas também de belos nomes: Aurora. Saudade, Formosa, Princesa Isabel...” (ARRIGUCCI, 1990, p. 202), construindo, como vimos, cenas com um caráter plástico e presentificado.

Na crônica “Álbum de Pernambuco”, Anan (2006) destaca esse caráter plástico do memorialismo de Bandeira em relação à cidade, por meio da contemplação de um livro de fotografias que o cronista ganhou, em que se confunde as memórias da infância e deformações do presente. Ela destaca esse memorialismo que aponta para a infância, sendo que a nostalgia se torna um dos traços mais marcantes da obra badeiriana como um todo.

É interessante ainda notar a saudade de um espaço que ele nem viveu, mas que nos remete a um memorialismo do passado brasileiro que Bandeira parece querer manter. $\mathrm{O}$ que está na citada crônica "Velhas igrejas" e na sua atenção pelo que não viu. Assim como o regionalista aprendiz, da crônica "Impressões de um cristão-novo do regionalista", analisada 
por Anan (2006), tem recordações daquilo que não viveu em relação a um passado dos engenhos do Nordeste.

Assim, percebemos que toda essa nostalgia é contraditória, há muito de tradicionalismo, mas que não é tranquilo, é, muitas vezes, tensionado pelo poeta, que é moderno, revelando estranhamentos do sujeito à sociedade. O processo histórico da modernização em Bandeira é ambivalente, combina nostalgia/memorialismo e tensão social/contradições inconciliáveis.

\subsection{Considerações finais}

Neste capítulo, discutimos, a partir da perspectiva de Antonio Candido, como a literatura mantém relação com a realidade social e, assim, incorpora as suas contradições. Se até 1930, deparamo-nos com uma consciência amena do atraso, a partir desse decênio, encontramos obras

marcadas pelo engajamento social, mesmo que inconscientemente. É também um momento de consolidação da poética modernista. Nesse período, destaca-se a obra de Manuel Bandeira madura, que carrega as contradições do país, que vive uma modernização problemática, em sua totalidade.

Nesse sentido, o próprio fazer poético é imerso em contradições. Em poemas e crônicas de Bandeira, percebe-se a ambiguidade da voz que fala no texto, a qual parece considerar um leitor brasileiro e cordial, participante da dinâmica social e buscar uma empatia com ele. Nessa busca, um estilo humilde é poeticamente construído, assim como há a construção de uma mitologia íntima com a desfiguração de dados aparentemente particulares que carregam ambivalências pessoais e históricas.

Esse estilo humilde, que é propositadamente construído e ambivalente, está na ambígua e conhecida característica de "poeta menor". Faz-se válido citar um trecho de Itinerário de Pasárgada que merece ser questionado:

Em "chanson des petits esclaves" e "Trucidaram o rio" aparece pela primeira vez m minha poesia e emoção social (...). Não se deve julgar por essas poucas e breves notas a minha carga emocional dessa espécie: intenso é meu desejo de participação, mas sei, de ciência certa, que sou um poeta menor. Em tais altas paragens só respira à vontade entre nós, atualmente, o poeta que escreveu o Sentimento do mundo e A rosa do povo. (BANDEIRA, 2012, p. 121).

Como vimos, essa humildade da voz narrativa não é literal, encontram-se nela desvios de sentido, ironias ("mas sei, de ciência certa, que sou um poeta menor"). A própria forma ambígua, construída para ser humilde, coloca Manuel Bandeira como um dos grandes poetas 
do século XX, contrário à conversa cordial com o leitor que diz "sou poeta menor, perdoai". Mas, a partir dessa imagem que o próprio poeta constrói para si, qual é a imagem construída pela crítica?

A humildade e a ternura construídas podem levar a uma leitura, também guiada no autorretrato feito no Itinerário, simplificadora, com aspectos selecionados por uma voz que quer se afirmar nessa humildade, assim como um "homem cordial" que quer se realçar nos aspectos positivos. Mas parte consequente da crítica, como os estudiosos abordados neste capítulo, olham com mais atenção e desconfiança esses efeitos poéticos e realçam os movimentos poéticos que consideram o leitor.

A crítica, então, parte dessa simplicidade, e a reconhece como aparente. Nota que nela há a articulação de experiências ditas íntimas e familiares, muito ligadas à importância da infância, da realidade brasileira e do modernismo. O que se relaciona também com o cotidiano e o prosaico da vida moderna em toda sua complexidade. Destaca-se também, nos estudos críticos comentados, a reorganização temporal como recurso formal, em que o passado insiste em se fazer presente, em um sujeito de uma realidade social baseada na condição de atraso.

É dessa forma que se percebe como a obra moderna de Manuel Bandeira, alimentada com a renovação formal alcançada no modernismo e também com fatos ordinários que ganham espaço na arte moderna, dialeticamente, carrega as heranças de um mundo contrário à modernidade, um mundo patriarcal com raízes na colonização brasileira, articulando modernidade e tradição. $\mathrm{O}$ passado permanece e o nacionalismo se faz presente como problema formal.

Assim, acha-se importante pensar o nacionalismo na obra de Manuel Bandeira, considerando o contex to do modernismo e a característica brasileira da cordialidade, parte de um contexto histórico e político de produção atravessado por forças contraditórias. Com isso, torna-se possível o questionamento: a voz lírica socialmente determinada e reveladora de contradições profundas sugere uma forma cordial? 


\section{Capítulo 2 - Discussões sobra a questão do Homem Cordial e relações com a literatura brasileira}

Este capítulo tem o objetivo de discutir a questão do "homem cordial", explicitando a relação entre a noção de cordialidade e a literatura associada a uma interpretação da modernidade brasileira. Ressalta-se que não se objetiva construir uma análise aprofundada de questões referentes às ciências sociais e de questões historiográficas, mas apresentar a literatura como caminho para debater a cordialidade. Este caminho escolhido pode mostrar, de forma distinta aos estudos sociais, tanto a validade como os limites desse pensamento de Sérgio Buarque de Holanda.

Para tanto, expõem-se algumas das interpretações de Brasil produzidas entre 1920 e 1930, os seus intérpretes, tais como Gilberto Freyre, Caio Prado Júnior e Sérgio Buarque de Holanda, e, assim, a noção de cordialidade. Defende-se, ainda, a atualidade de discutir essa noção, por meio de estudos que ainda hoje a problematizam, como o recente $A$ tolice da inteligência brasileira, de Jessé de Souza.

Em seguida, busca-se discutir as relações existentes entre essa caraterística e a literatura brasileira com obras, críticas ou literárias, que as indicam, explicitamente ou não, tal como Drummond Cordial, de Jerônimo Teixeira. Abordar essas relações é importante para entender como o aspecto da cordialidade, síntese de atitudes do brasileiro, faz-se presente no contexto de produção que se analisa com a obra de Manuel Bandeira, evidenciando diálogos de autores nesse contexto e a relação forma artística e processo histórico, além de evidenciar a cordialidade como parte desse processo em movimento no Brasil.

\subsection{Pensar o Brasil: olhares sobre a história de um país colonial}

Entre 1920 e 1930, as discussões sobre a nação se apresentam de forma bastante relevante no Brasil, aparecendo tanto na arte modernista como no pensamento dos chamados intérpretes do Brasil. Há, segundo Antonio Candido, um enorme interesse pelo que se pode chamar de "explicações do Brasil". Ele afirma:

Interesse simbolizado de certo modo por uma iniciativa editorial de grande importância, a coleção Brasiliana da Companhia Editorial Nacional (...). Essas explicações se concentravam sobretudo no passado e podem ser exemplificadas por duas obras de enorme influência: Populações meridionais 
do Brasil (1920), de Oliveira Lima, e Casa-Grande e Senzala (1933), de Gilberto Freyre. Raízes do Brasil (1936) é menos ambicioso e se distingue por um traço peculiar: parece escrito pensando no presente e deságua numa reflexão política de singular atualidade. (CANDIDO, 1998, p. 84).

Candido escreve essas observações pensando principalmente no último capítulo de Raízes do Brasil, no qual Sérgio Buarque sugere uma solução de cunho democrático-popular ligada ao fim da tradição colonial, pensando no Brasil do seu tempo, marcado por uma urbanização que dissolve valores próprios da tradição colonial. Essa reflexão política ainda hoje, em 2016, no ano em que se comemoram os 80 anos de Raízes do Brasil, faz-se atual e necessária. É inegável o caráter inovador desse estudo no conjunto de obras produzidas nessa década, na qual tanto interesse por compreensão do Brasil foi verificado.

No ensaio "Sobre a formação da literatura brasileira", o crítico literário Roberto Schwarz (1999) sintetiza a relação das obras de intelectuais que refletem sobre a formação brasileira, Gilberto Freyre, Sérgio Buarque e Caio Prado, além do próprio Antonio Candido. Essas obras, com diferenças fundamentais entre si, são centrais ao se pensar o alcance e os limites das explicações do país.

É importante, além das diferentes perspectivas relacionadas com uma história de colonização, o fato de as ideias abordadas por esses autores serem marcadas por juízos de valor que se referem à sua atualidade histórica, como bem destaca Schwarz:

Nos quatro exemplos [Gilberto Freyre, Sérgio Buarque, Caio Pardo e Celso Furtado], o ponto de fuga do processo é fortemente impregnado de valor, negativo e positivo, e diz respeito direto à atualidade vivida pelos autores. Sob esse aspecto, o livro de Antonio Candido [Formação da Literatura Brasileira], em parte pela natureza do assunto, difere de seus pares. (SCHWARZ, 1999, p. 18).

Dessa forma, Roberto Schwarz (1999) aponta um saudosismo em Gilberto Freyre com a perda do passado colonial. Não que seja um saudosismo que quer a volta desse passado, mas não se espera um rompimento total com certos elementos do "atraso" e é observada criticamente a modernidade excludente.

Gilberto Freyre (1963), com essa perspectiva apontada por Roberto Schwarz (1999), analisa a sociedade agrária, escravocrata e híbrida que se forma na América tropical. Em CasaGrande \& Senzala, Freyre (1963) mostra a importância da família (rural, escravocrata da casagrande e patriarcal) na colonização do Brasil, configurando-se como uma forma social que se desdobra em forma política, algo importante ao processo de colonização que reverbera na ideia de identidade do Brasil e no processo de formação e de evolução da sociedade: “A família, não 
o indivíduo, nem tampouco o Estado nem nenhuma companhia de comércio, é desde o século XVI o grande fator colonizador no Brasil (...) constituindo-se na aristocracia colonial mais poderosa da América” (FREYRE, 1963, p. 83).

Freyre (1963) aborda também a sociedade brasileira como a sociedade da América que se constituiu mais harmoniosamente quanto às relações de raça, e na qual vê-se constantemente uma perspectiva mais conciliatória em torno de alguns problemas, o que se traduz no saudosismo colonial citado e na defesa da sociedade híbrida.

Já Sérgio Buarque de Holanda, em Raízes do Brasil, traz, conforme Roberto Schwarz (1999), aspectos mais negativos relativos às nossas raízes portuguesas e ao nosso passado colonial e rural, que entra em contradição com a modernização e com as bases de uma sociedade democrática. Sérgio Buarque, assim como Freyre, também percebe a importância da família na formação nacional e a problematiza em suas relações com o Estado.

Há, nessa obra, uma esperança para revogar a velha ordem e suas consequências, o que se observa, por exemplo, na revolução vertical que o estudioso analisa ser a saída democrática para o Brasil, algo que potencialmente romperia com nossas raízes personalistas.

Para Schwarz (1999), Caio Prado também aborda uma matriz colonial que precisa ser superada, o atraso econômico, que envolve a história de escravidão, monocultura, incultura etc. Dessa matriz, segundo Schwarz, resultam subordinação em relação às nações exploradoras e perpetuação da exploração na formação do Estado brasileiro.

Schwarz (1999) comenta ainda sobre Celso Furtado, que analisa o problema da superação dessa herança colonial relacionado ao fato das importantes decisões econômicas do Brasil estarem fora do país, sendo necessário uma interiorização dos comandos das relações econômicas.

Esses estudiosos citados pelo crítico pensam a nação em um contexto em que a história escravista brasileira se choca com a atualidade ocidental da época. As questões por eles abordadas vão ser importantes no decênio de 30, momento central para se pensar a reinvenção moderna do nacionalismo no Brasil. É nesse contexto que surge a discussão do conceito de "homem cordial” na perspectiva trabalhada por Sérgio Buarque em Raízes do Brasil.

Para Antônio Candido (1995), em "O significado de Raízes do Brasil”, Gilberto Freyre, Sérgio Buarque de Holanda e Caio Prado Jr. renovaram o pensamento sobre o Brasil com visões que traziam, de formas diversas, entre 1933 e 1942, “a denúncia do preconceito de raça, a valorização do elemento cor, a crítica dos fundamentos patriarcais e agrários, o discernimento das condições econômicas, a desmistificação da retórica liberal” (CANDIDO, 1995, p. 11). 
Essa renovação de pensamento evidencia transformações das condições econômicas, sociais e culturais da sociedade, as quais têm como marco fundamental a década de 30, como já foi diagnosticado neste trabalho, no capítulo anterior, a partir da leitura de outro ensaio de Candido, "A revolução de 30 e a cultura".

Nesse contexto, em "O significado de Raízes do Brasil”, Candido (1995) esclarece que, conforme a reflexão social latino-americana, marcada pelo senso dos contrastes, Raízes do Brasil tem uma metodologia dos contrários, encontrando a solução numa interpretação dialética da brasilidade que, por isso mesmo, é também mais dinâmica. Com isso, Sérgio Buarque apontaria traços de um processo histórico de constituição da sociedade brasileira e, como consequências desses traços, abordaria, como argumento central, a noção de cordialidade.

Assim, em Raízes do Brasil, abordam-se aspectos que influenciariam, não de forma mecânica, mas dinâmica, a construção histórica da cordialidade, tais como o personalismo português; a permeabilidade da nobreza de Portugal; a colonização de terras tropicais; a mestiçagem como processo normal para os colonos portugueses; o latifúndio agrário justificado não só pelo meio, mas por uma necessidade de mercado da Europa; o meio rural como a base da nossa sociedade colonial; a crise existente do fato de se implantar, num país preso à economia escravocrata, bases da democracia moderna burguesa; a valorização do trabalho intelectual em desprezo ao manual, o que se relaciona à fidalguia portuguesa, entre outros fatores trabalhados em seus paradoxos e tensões dialéticas.

É importante destacar, como Caio Prado Júnior (2000) salienta, que a colonização brasileira é parte de um todo, o chamado mundo moderno, integrado pelos processos de colonização, comandados pela Europa. Diante disso, importa também, não só a colonização brasileira, mas a iniciativa, os motivos e os rumos e objetivos da empreitada mercantil, que passam pela revolução na navegação, pela boa localização portuguesa, pelo interesse pelo comércio e pelo pioneirismo português.

Também é importante considerar o sentido da colonização no Brasil, que, conforme Caio Prado (2000), deve ser explicado em relação ao mercantilismo: "Este início, cujo caráter se manterá dominante através dos três séculos que vão até o momento em que ora abordamos a história brasileira, se gravará profunda e totalmente nas feições e na vida do país." (PRADO, 2000, p. 20).

Dessa forma, considera-se neste trabalho a cordialidade relacionada a uma série de fatores integrantes de um processo histórico, que marcam o Brasil ainda hoje e que estão presentes no esforço de se pensar o país em uma época de modernização que se combina 
contraditoriamente com o atraso resultante da herança colonial estudada pelo campo histórico e sociológico, o que também vai estar presente nas formas estéticas do período.

Para o professor João Luiz Lafetá,

A década de 30 deu-nos algumas das obras mais realizadas e alguns dos escritores mais importantes da literatura brasileira. Na poesia bastaria lembrar a qualidade dos dois estreantes (em livro) de 1930, Carlos Drummond de Andrade e Murilo Mendes, acrescentando ainda que o período tem Remate de Males, Libertinagem e Estrela da Manhã, além de Jorge de Lima, na prosa de ficção o romance social de José Lins do Rego, Jorge Amado e Rachel de Queiroz, o ponto alto atingido por Graciliano Ramos; no ensaio os estudos históricos e sociológicos de Gilberto Freyre, Caio Prado Jr., Sérgio Buarque de Holanda, o próprio Mário de Andrade. (...)

(...) A revolução de 30, com a grande abertura que traz, propicia - e pede - o debate em torno da história nacional, da situação de vida do povo no campo e na cidade, do drama, das secas etc. O real conhecimento do país fazse sentir como uma necessidade urgente e os artistas são bastante sensibilizados por essa exigência. (LAFETÁ, 2004).

Libertinagem, obra citada por Lafetá (2004), tanto pelos aspectos formais quanto pelos aspectos temáticos, envolvem esse esforço de se pensar o Brasil que pede esse debate em torno da história nacional, concretizada, no campo do ensaio, pelos intérpretes do Brasil citados aqui.

Considerando esse debate em torno da nação, torna-se visível na obra bandeiriana contradições da modernidade em um país periférico, como, por exemplo, em "O cacto":

[...] O cacto tombou atravessado na rua,

Quebrou os beirais do casario fronteiro,

Impediu o trânsito de bondes, automóveis, carroças,

Arrebentou as cabos elétricos e durante vinte e quatro horas privou a cidade

[de iluminação e energia:

- Era belo, áspero, intratável."

(BANDEIRA, 2009, p. 128).

Nesse poema, entre outros aspectos, temos uma cidade moderna privada de aspectos da modernidade (trânsito de bondes e automóveis, iluminação e energia), problematizada, revelando uma forma irônica no tratamento do Brasil moderno.

A obra de Bandeira, sutilmente, como está em "O cacto" e em muitos outros poemas, dialoga com as discussões sobre o Brasil fundamentais do período e declara uma preocupação com as coisas brasileiras que se dá com uma observação crítica.

Considerando essa observação, há, em muitos poemas e crônicas, certo saudosismo, que se relaciona com o passado colonial da Nação e o aproxima da perspectiva de Gilberto Freyre caracterizado por Roberto Schwarz (1999). O poema "Evocação do Recife", por exemplo, foi 
feito a pedido de Freyre e evoca, como veremos detidamente no capítulo 3 deste trabalho, imagens que, assim como em "O cacto", são privadas de aspectos da modernidade em uma atenção ao que não é moderno mediado por uma saudade da infância.

Em outros poemas, imagens coloniais aparecem mais claramente, como em "Recife", de Estrela da Tarde, com publicação já em 1963:

(...)

Um Recife ainda do tempo que meu avô materno

Alforriava espontaneamente

A moça preta Tomásia, sua escrava,

Que depois foi nossa cozinheira

Até morrer

Recife.

(BANDEIRA, 2009, p. 249).

Nesse poema, há um saudosismo por um Recife da infância ("Não como és hoje,/Mas como eras na minha infância”). E, nos versos citados, já se percebe que, além de um olhar crítico à modernização, afirmada, de forma diferente, também em "O cacto", há um não rompimento com um passado patriarcal e escravocrata, discutindo-se as marcas da nossa história de colonização, o que vai estar presente em alguns poemas da obra de Bandeira.

\subsection{O Homem Cordial}

Como se sabe, a expressão "homem cordial" surgiu primeiramente com Ribeiro Couto, na observância de aspectos culturais que diferenciariam os latino-americanos dos europeus. Primeiramente seriam cordiais os povos da América Latina, pois são os que gostam de conversar e os que têm uma fácil expressão de sentimentos bons. É dessa forma que o conceito aparece pela primeira vez para caracterizar o brasileiro, como podemos perceber no trecho de carta escrita em 1931:

É da fusão do homem ibérico com a terra nova e as raças primitivas, que deve sair o 'sentido americano' (latino), a raça nova produto de uma cultura e de uma intuição virgem - o Homem Cordial. Nossa América, a meu ver, está dando ao mundo isto: o Homem Cordial. O egoísmo europeu, batido de perseguições religiosas e de catástrofes econômicas, tocado pela intolerância e pela fome, atravessou os mares e fundou ali, no leito das mulheres primitivas e em toda a vastidão generosa daquela terra, a Família dos Homens Cordiais, esses que se distinguem do resto da humanidade por duas características essencialmente americanas: o espírito hospitaleiro e a tendência à credulidade. Numa palavra, o Homem Cordial. (...) 
Somos povos que gostam de conversar, de fumar parados, de ouvir viola, de cantar modinhas, de amar com pudor, de convidar o estrangeiro a entrar para tomar café, de exclamar para o luar em noites claras, à janela: Mas que luar magnífico! Essa atitude de disponibilidade sentimental é toda nossa, é ibero-americana... Observável nos nadas, nas pequeninas insignificâncias da vida de todos os dias, ela toma vulto aos olhos do crítico, pois são índices dessa Civilização Cordial que eu considero a contribuição da América Latina ao mundo. (COUTO, 1931. In: BEZERRA, p. 125).

Vamos enxergar algo da dimensão cordial também em Sobrados e mucambos, obra, assim como Raízes do Brasil, publicada em 1936 e em que Gilberto Freyre assume essa perspectiva culturalista em relação à cordialidade. Na perspectiva de Freyre, a cordialidade origina-se principalmente do mulato e se relaciona mais com a ideia de simpatia:

Ninguém como eles [os mulatos] é tão amável; nem tem um riso tão bom; uma maneira mais cordial de oferecer ao estranho a clássica xicrinha de café; a casa; os préstimos. Nem modo mais carinhoso de abraçar e de transformar esse rito como já dissemos orientalmente apolíneo de amizade entre homens em expansão caracteristicamente brasileira, dionisiacamente mulata, de cordialidade. (FREYRE, 1951, p. 1059).

Essa cordialidade característica do mulato é, para Freyre, como um meio do mulato livre ascender socialmente:

O mulato formado, em competição com o advogado branco, com o médico, com o político, procurou vender o competidor, agradando, mais do que eles, aos clientes, ao povo (...). Seu riso foi não só um dos elementos, como um dos instrumentos mais poderosos de ascensão profissional, política, econômica; uma das expressões mais características de sua plasticidade, na transição do estado servil para o de mando ou domínio, ou, pelo menos de igualdade com o dominador branco. (FREYRE, 1951, p. 1063, v. 3).

Freyre cita ainda o uso frequente de diminutivos e diz que esse uso é para criar intimidade com as pessoas:

Principalmente com as pessoas mais importantes: "sinhozinho", "doutorzinho" (...) E esse desejo de intimidade com as pessoas nos parece vir (...) de condições peculiares ao período de rápida ascensão de um grupo numeroso - o grupo mulato - ansioso por encurtar, pelos meios mais doces, a distância social entre ele e o grupo dominante. (FREYRE, 1951, p. 1064, v. $3)$.

É perceptível que essa simpatia, muitas vezes, esconde uma violência que existe nas diferenças entre as classes sociais e no sistema de produção, como revelação dos desequilíbrios 
existentes no Brasil. Se, entretanto, Freyre possui um olhar que relaciona a cordialidade com a simpatia do mulato e com uma forma mais harmônica, Buarque considera mais a dimensão organicamente política e social do Brasil.

Assim, foi em Raízes do Brasil que o conceito se popularizou e ganhou problematizações e explicações teóricas, considerando-se o contexto político e as instituições. Sérgio Buarque de Holanda foi capaz de dar uma dimensão dialética e histórica ao conceito, pois ele pensa a cordialidade não só como algo positivo, pelo ao contrário, a sua perspectiva é a de quem considera-a algo principalmente negativo. $\mathrm{O}$ capítulo 5 da obra citada trata especificamente da cordialidade, iniciando-se com a explicação de que o Estado não pode ser uma ampliação da família e que, nele, o geral deve prevalecer sobre o particular, algo refratário ao comportamento e à concepção de mundo do "homem cordial".

No Brasil, há um significativo desequilíbrio social acarretado pelo choque do desenvolvimento da urbanização com a família patriarcal (medular na sociedade brasileira) e com a nossa herança ibérica. Nesse desequilíbrio, destaca-se a principal dificuldade desse "homem cordial": discernir racionalmente o público do privado.

Segundo Sérgio Buarque:

No Brasil, onde imperou, desde os tempos remotos, o tipo primitivo da família patriarcal, o desenvolvimento da urbanização - que não resulta unicamente do crescimento das cidades, mas também do crescimento dos meios de comunicação, atraindo vastas áreas rurais para a esfera de influências das cidades - ia acarretar um desequilíbrio social, cujos efeitos permanecem vivos ainda hoje. (HOLANDA, 1963, p. 135).

Nesse contexto de urbanização e modernização problemática, emerge a figura característica do "homem cordial", que, no contexto brasileiro, traz consigo influências dos padrões formados no meio rural marcado pelo latifúndio, guardando-se, nesse processo, algo do prevalecimento do indivíduo sobre o social, o que se reflete em vários âmbitos da vida social brasileira, como na política, na justiça e na religião, e aproxima esse homem ao funcionário patrimonial descrito por Sérgio Buarque de Holanda (1963).

Diferenciando-o do puro burocrata de Max Weber, Sérgio Buarque caracteriza esse funcionário patrimonial. Segundo ele, a gestão política, para o funcionário patrimonial, é de interesse particular e, por isso, não haveria ordenação impessoal típica do Estado burocrático, apesar de ser possível notar-se traços dele. Assim, Buarque (1963) afirma que é possível acompanhar, ao longo da história do Brasil, o predomínio constante das vontades particulares 
em detrimento de uma ordenação burocrática impessoal, que se realize além das relações criadas na vida doméstica que se configuram como modelo das composições sociais.

Somado a isso, é importante destacar que essas características cordiais são contrárias a conceitos basilares do mundo moderno, tal como sugere Sérgio Buarque:

Com efeito, onde quer que prospere e assente em bases muito sólidas a ideia de família - e principalmente onde predomina a família de tipo patriarcal - tende a ser precária e a lutar contra fortes restrições a formação e evolução da sociedade segundo conceitos atuais. A crise de adaptação dos indivíduos ao mecanismo social é, assim, especialmente sensível no nosso tempo devido ao decisivo triunfo de certas virtudes antifamiliares por excelência, como são, sem dúvida, aquelas que repousam no espírito de iniciativa pessoal e na concorrência entre os cidadãos. (HOLANDA, 1963, p. $133)$.

Ou seja, na visão de Sérgio Buarque, há uma falta de concordância do mundo moderno e dos laços de afeto e de sangue das famílias patriarcais. Esses laços tendem, na modernidade, a ser substituídos por instituições com princípios abstratos e por conceitos tais como o de mercado. Esse processo não é pacífico num ambiente onde a família patriarcal estruturou por tanto tempo a base da sociedade como um todo.

Com essas considerações, Sérgio Buarque (1963) afirma ser a cordialidade um traço definidor do modo como a sociedade brasileira se organiza. Ele, considerando o significado de "relativo ao coração", destaca que esse traço pode trazer tanto a amizade como a inimizade, ou seja, dialeticamente, engloba sentimentos bons e ruins, mas que, ao predominar no Estado moderno, acarreta desequilíbrios negativos, limita o racional e a democracia.

Para Sérgio Buarque, a cordialidade afasta-se da polidez. Segundo ele, o homem polido até apresenta características cordiais, mas de forma artificial, e, na cordialidade, por sua vez, apresentam-se "expressões legítimas de um fundo emotivo extremamente rico e transbordante" (HOLANDA, 1963, p. 137). Afirma ainda, em uma generalização com poucas justificativas, que "nenhum povo está mais distante dessa noção ritualista da vida do que o brasileiro" (HOLANDA, 1963, p. 137). Essa aversão ao ritualismo é exemplificada pela dificuldade de uma reverência prolongada a superiores, preferindo estabelecer um convívio particular e íntimo.

Sérgio Buarque (1963) constrói a cordialidade como um tipo dicotômico à polidez, dando um olhar negativo à cordialidade e positivo à polidez, algo justificável no momento de Raízes do Brasil na observância das contradições do país. Mas, hoje, é importante destacar que nem a cordialidade nem a polidez, apoiada em um progresso racional e modernizador, existem como tipos puros da realidade. Mas esses tipos apresentam aspectos de comportamento 
relacionadas à organização da sociedade brasileira e nos ajudam a entender as nossas contradições e a de como o capitalismo se estabelece na periferia.

Destaca-se, com isso, a citada preferência pelo convívio íntimo, que, para Sérgio Buarque (1963), influencia em outros aspectos da vida social, tal como no linguístico. Como foi citado no capítulo 1, o uso excessivo de diminutivos no português brasileiro serve para uma maior familiarização, conferindo um tom afetuoso oposto a algo mais urbano e cosmopolita. No Brasil, essa característica mostra como traços mais rurais permanecem até em lugares mais urbanizados.

Há também a tendência à omissão do nome de família no tratamento social, o que se configura como o oposto do que acontece em outros países. É uma tendência que possui uma tradição entre os portugueses, considerando que os nomes de família só predominaram na Europa a partir do século XII, e que se fixou no Brasil, realçando um grupo social que prefere basear as relações na simpatia e repelem uma disciplina de raciocínio abstrato, como salientou Sérgio Buarque (1963).

Outro aspecto característico do modo de ser cordial relaciona-se à religiosidade tipicamente brasileira (quando se fala da religião católica herdada do colonizador e incorporada aqui), na qual, segundo Buarque (1963), há uma intimidade com os santos e se configura com o horror às distâncias, além da aversão ao ritualismo, o que teria corrompido nosso sentimento religioso. Assim, o autor define a religião católica no Brasil como de superfície, mais atenta à pompa exterior, com dificuldades em relação a solenidades, à rigidez etc.

Vale lembrar que alguns poemas citados no capítulo 1 deste trabalho demonstram esses aspectos elencados como característico de "homem cordial” por Sérgio Buarque também como aspecto formal na poética de Manuel Bandeira. Um exemplo seria o poema "Oração a Santa Terezinha do Menino Jesus", versos como “Santa Teresa não, Teresinha” representa a criação de uma intimidade com a santa em uma relação que se prefere o íntimo e um tom afetuoso construído pelo diminutivo que não deixa de ser irônico. Tais recursos é de uma voz lírica que parece basear sua relação a critérios de simpatia. Vale ressaltar que essa relação íntima é estabelecida também com o seu leitor, como foi analisado a partir da discussão em torno da sua fortuna crítica e será melhor visualizado no capítulo 3 deste trabalho, o que sugere contradições fundamentais no Brasil.

Como comenta Antonio Candido (1995), em Raízes do Brasil, Sérgio Buarque sugere contradições não resolvidas ocasionadas pela dissolução da ordem tradicional, as quais se manifestam nas instituições, além de assinalar como pressuposto fundamental a passagem do rural para o urbano, na qual a mentalidade urbana foi contaminada pela rural, já que os cargos 
mais importantes eram ainda dos senhores de terra. A cordialidade é, então, parte importante dessas contradições.

Candido (1995) destaca, ainda, a distinção feita, em Raízes do Brasil, entre a colonização hispânica e a portuguesa. Sendo que a primeira se caracterizou pela criação de núcleos de povoação bem ordenados e almejava-se fazer um prolongamento da metrópole, diferente da colonização portuguesa, marcada principalmente pela exploração comercial. Além disso, a colonização castelhana preferiu terras do interior e os planaltos, enquanto a portuguesa se fixou principalmente no litoral.

Apesar das especificidades de cada colonização, o "homem cordial" não é uma exclusividade brasileira, é algo característico dos povos latinos, usado para se pensar as contradições brasileiras por Sérgio Buarque, que o associa a um caráter brasileiro, levando a uma ideia de um conceito puro e dado da realidade, e não a de uma noção abstrata que é. Não deve ser pensado como um produto histórico absoluto, mas se relaciona à formação histórica da América Latina, sendo que, para Buarque, características ibéricas dos colonizadores, como o personalismo, a ausência de hierarquia e a frouxidão das instituições, apontadas em Raízes do Brasil, influenciaram nas colônias, já que

É significativa, em primeiro lugar, a circunstância de termos recebido a herança através de uma nação ibérica. A Espanha e Portugal são, com a Rússia e os países balcânicos (e em certo sentido também a Inglaterra), um dos territórios-ponte pelos quais a Europa se comunica com os outros mundos. Assim, eles constituem uma zona fronteiriça, de transição, menos carregada, em alguns casos, desse europeísmo que, não obstante, mantém como um patrimônio necessário. (HOLANDA, 1963, p. 4).

Jerônimo Teixeira (2005) discute essa questão da cordialidade como algo não exclusivo do brasileiro, ressaltando as afinidades de ideias do argentino Jorge Luís Borges e de Sérgio Buarque de Holanda que envolvem a incapacidade de entender a abstração do Estado.

Para Teixeira (2005), a cordialidade "não é um problema moral, mas uma realidade histórica", intensificada no Brasil pela permanência da importância do meio rural sobre o meio urbano. Além disso, adverte: "O homem cordial seria impensável sem o estigma fundamental da civilização brasileira - a escravidão", ou seja, há uma violência profunda na constituição da sociedade brasileira que se faz presente no conceito. Entende-se que não é possível pensar o Brasil sem a consideração dessa prática social e das implicações que ela causou na sociedade, as quais estão presentes na contradição entre o "mundo moderno" e "modo de ser" de um povo que carrega séculos de escravidão e agrarismo. O que está presente na poesia de Manuel 
Bandeira em vários poemas, como "Cunhantã" ou "Irene no céu", com personagens, como Siquê e Irene claramente fruto da escravidão e envolvidas nesse estigma.

A professora Maria Odila Leite da Silva Dias (1998), em "Política e sociedade na obra de Sérgio Buarque de Holanda", destacou o "homem cordial" como "eventualmente violento e anárquico", e associou a cordialidade a uma preocupação da elite de manter uma aparente harmonia, que esconde uma violência de fundo. O que está, por exemplo, no costume citado de rejeitar o emprego do sobrenome nos tratamentos pessoais, um sintoma, segundo professora, da necessidade de aparentar harmonia, de desfazer diferenças e apelar para o emotivo e o íntimo. Ora, o sobrenome substituído por Gostoso em "Poema tirado de uma notícia de jornal" de Manuel Bandeira não tem algo dessa apelação ao íntimo e uma suposta harmonia que parece esconder, mas também revela, a violência que classes sociais mais baixas sofrem no Brasil?

Ainda segundo Maria Odila (1998), Buarque criticava reformas que, ao invés de desencadearem mudanças efetivas na sociedade, reforçavam as tradições graças à origem elitista das reformas e mudanças. Dessa forma, uma verdadeira mudança, além de ser necessária a liquidação dos fundamentos personalistas da nossa vida social, partiria das massas, e não das camadas superiores.

O reforço da tradição graças à origem elitista das mudanças também está presente na poesia bandeiriana que, muitas vezes, olha criticamente a modernidade excludente, como acontece no poema citado, "Poema tirado de uma notícia de jornal", que veremos mais atentamente no capítulo 3 deste trabalho.

\subsubsection{A cordialidade: problematizações propostas ao longo do tempo}

A tentativa de se conceituar "cordialidade" se relacionou, no período de Raízes do Brasil, com a busca de uma especificidade do caráter brasileiro. Essa busca está em Raízes do Brasil, não como uma exaltação ufanista do nacional, mas como uma percepção crítica, em que o conceito pretende sistematizar problematicamente algo que se faz vivo em um processo social mutável.

A cordialidade, como estabelecida por Sérgio Buarque, sempre permitiu, e permite, vários questionamentos, como as feitas por Cassiano Ricardo. Alguns dos questionamentos propostos, e a reposta a eles, auxiliam na reflexão sobre a noção de "homem cordial".

Cassiano Ricardo (1963) propõe questões relativas ao tema, que foram posteriormente respondidas por Sérgio Buarque. No artigo "Variações sobre o Homem Cordial", publicado na revista Colégio, Ricardo destaca o fato de que, mesmo com o racionalismo e a mecanização, a 
noção de "cordial" é aplicável a todos os seres humanos, ainda que seja esta uma característica mais permanente em alguns povos. Com isso, o autor levanta dúvidas em relação ao termo ser usado para designar especificamente o brasileiro como uma simples fórmula arbitrária.

Além disso, a contestação de Ricardo (1963) é centrada no termo cordialidade, que pode ter a acepção de polidez, mas teria sido usada para dizer o oposto. Cassiano Ricardo coloca o termo em uma oposição à bondade, afirmando que seria essa a característica brasileira. $\mathrm{O}$ ensaísta, parecendo se apoiar em mitos que exaltam o Brasil, afirma que a nação tem, de fato, um fundo mais emotivo, e que o brasileiro sabe tirar partido dessa bondade, que, entranhandose nos âmbitos social e político, seria fundamento da nossa democracia social:

Trata-se, pois, de uma bondade mais envolvente, mais política, mais assimiladora. Fôrça secreta e invisível que tudo domina e que tudo submete com doçura, fazendo mais que tôdas as tiranias ou técnicas de Sorel que dividem os homens e que só os submetem com violência e à custa de sangue. Poder-se-ia dizer que se trata, em nosso caso, de uma bondade que se defende sempre, mesmo quando parece submeter-se. E que cria raízes afetivas de solidariedade no jogo multiplico e promíscuo dos interesses rivais. A função desse material afetivo não é a simples polidez. É mais uma função biológica, social. (...)

O nosso povo formou-se pela conciliação de todos os conflitos humanos numa só forma de convivência, num estilo de vida que consiste em ter criado o máximo de felicidade social até hoje sonhado por teorias e profetas. Desde o primeiro momento, abrigou o nosso céu os oprimidos, os desajustados, os atirados às praias. (RICARDO, in: HOLANDA, 1963, p. 204).

Nesse sentido, algo caracteristicamente brasileiro, como se conhece no senso comum, seria a hospitalidade. Cassiano Ricardo (1963) lembra que o brasileiro foi muito menos cruel nas conquistas dos bandeirantes que outros povos, por exemplo. Ricardo (1963) tem uma visão otimista e de conciliação harmônica que não observa uma totalidade.

Ele observa a bondade como arma, que era, por exemplo, arma política na catequese dos indígenas, a partir do costume de dar bugigangas aos índios como melhor forma de dominá-los, forma que "encheu a história do conquistador em suas relações diárias com as tribos, inclusive as mais rebeldes. " (RICARDO. In: HOLANDA, 1963, p. 205).

Cassiano Ricardo (1963) exemplifica essa ideia de bondade como arma também ao lembrar o fato de o senhor de engenho deixar os escravos cantarem no trabalho, sendo que "o patrão, o senhor de engenho, o fazendeiro só foram bem sucedidos quando transformaram a bondade numa arma econômica.” (RICARDO. In: HOLANDA, 1963, p. 205). 
O pensamento de Ricardo (1963) é repleto de incongruências e mitos ufanistas, como o de que não enfrentamos preconceitos raciais ou problemas com as minorias, e revela uma visão mais positiva da cordialidade, assim como fizera Gilberto Freyre no uso da palavra. Somado a isso, Cassiano Ricardo (1963) cita a religião católica como determinante da característica de bondade social, a ausência de atritos econômicos, a índole herdada do português e, em decorrência disso, argumenta sobre a incapacidade de o brasileiro ter ódio ou preconceito, o que configuraria a democracia social como estilo de vida brasileiro.

Essas afirmações são contestadas por Sérgio Buarque de Holanda (1963) em carta a Cassiano Ricardo. Ele afirma considerar o sentido etimológico da palavra "cordialidade", que possui o significado de ser relativo ao coração, e destaca que usa esse termo por não existir outro melhor. Sérgio Buarque frisa também que associa a "cordialidade" a condições da vida rural e colonial da sociedade brasileira, algo que vai sendo superado com o desenvolvimento das cidades:

(...) a própria cordialidade não me parece virtude definitiva e cabal que tenha de prevalecer independente das circunstâncias mutáveis de nossa existência. (...) Associo-a antes a condições particulares de nossa vida rural e colonial, que vamos rapidamente superando. Com a progressiva urbanização, que não consiste apenas no desenvolvimento das metrópoles, mas ainda e sobretudo na incorporação de áreas cada vez mais extensas à esfera da influência metropolitana, o homem cordial se acha fundado a desaparecer, onde ainda não desapareceu de todo. E ás vezes receio sinceramente que já tenha gasto muita cêra com esse pobre defunto. (HOLANDA, 1963, p. 213).

Ou seja, com o termo cordialidade associado a uma categoria característica pretensamente brasileira, o autor de Raízes do Brasil quis sintetizar, considerando o passado, o presente e o futuro, uma problemática que acompanha a história, resultado de uma herança histórica e que tende a mudar com novos contextos sociais.

Recentemente, Jessé Souza (2015), em A tolice da inteligência brasileira, critica a interpretação da realidade social brasileira dominante no século XX, que passa por Gilberto Freyre e por Sérgio Buarque.

Para ele, Gilberto Freyre criou mitos da identidade nacional que foram apropriados como ciência sociológica. Nisso, havia uma fantasia compensatória e um olhar para o afeto, nossa inferioridade, como virtude para criar um orgulho brasileiro. Souza (2015) afirma também que Sérgio Buarque apenas inverte o pressuposto de Freyre, dando um olhar negativo ao afeto e caracterizando o "homem cordial" como o nosso maior problema social e político. 
O professor Jessé Souza (2015) condena a análise de Sérgio Buarque por ser centrada apenas no Estado, mesmo que a cordialidade esteja presente em todas as dimensões da vida, o que pode levar a um entendimento simplista da dialética mercado capitalista e Estado, tido como naturalmente corrupto: "É que Buarque reinterpreta o "personalismo" freyriano (...) em "patrimonialismo". Nesta noção, o Estado e seus agentes passam agir como age o "homem cordial" na vida cotidiana". (SOUZA, 2015, p.48).

Assim, além de apresentar o problema do patrimonialismo apenas estatal, que torna a corrupção política um tema central do debate político brasileiro, Souza (2015) faz uma crítica na oposição entre a racionalidade dos Estados Unidos e essa cordialidade, tendo-se como resultado uma idealização dos Estados Unidos e uma inferiorizarão do brasileiro, acrescentando reflexões importantes para se pensar a abrangência da conceituação da cordialidade:

O fundamento implícito de todo raciocínio de Buarque no seu principal livro é a oposição entre duas abstrações: "o homem cordial", como tipo genérico brasileiro; e o "protestante ascético", como seu contraponto norte-americano. O homem cordial é simplesmente o corolário do mito nacional (...): um indivíduo emotivo que guia as escolhas por preferências afetivas e pessoais. O protestante ascético é percebido como seu contrário especular: um indivíduo "racional" guiado por considerações impessoais e comunitárias. (SOUZA, 2015, p. 45).

O conceito apresenta essa idealização dos Estados Unidos em contraponto com a situação brasileira, naturalizando uma ideia, negativa, de Brasil presente hoje, assim como apresenta a ideia de Estado naturalmente corrupto, com uma demonização deste em relação ao mercado.

Jessé Souza (2015) critica também o fato de esse conceito esconder os conflitos de classe de um país tão desigual, já que o "homem cordial" é apresentado como um ser genérico, de todas as classes.

Critica similar fez Dante Moreira Leite em 1969, conforme analisa Jerônimo Teixeira (2005), na obra Drummond Cordial. Moreira Leite, que foi cientista social em várias frentes e professor do Departamento de Psicologia Social e do Trabalho da Universidade de São Paulo, afirma que o conceito como realidade social brasileira só seria pertinente se abrangesse de maneira válida todas as classes sociais, mas tem efeitos restritos pois aborda apenas a classe alta.

Teixeira (2005) contra-argumenta afirmando que, ao contrário de Moreira Leite, que vê com rigidez a noção de classe social, Buarque cria um modelo mais dinâmico de observação da sociedade e afirma que ter como norma de conduta o patriciado rural para todas as classes é um 
dos efeitos da improvisação da burguesia urbana no Brasil. Ademais, além de a cordialidade ser mutável, ela seria uma tendência social, e não uma determinante psicológica.

O fato é que o conceito é por si só ambíguo, contraditório e possui abordagens tanto positivas como negativas. Da forma como é concebida por Sérgio Buarque, a ideia de cordialidade exprime criticamente o afeto tido como princípio social que acompanha dicotomias brasileiras fundamentais, urbano/rural e atraso/progresso, e, assim, não nega um processo histórico marcado pela escravidão, exclusão de classes e violência. Algo que a literatura pode nos ajudar a perceber, como veremos nas análises de poemas como "Irene no céu" ou outros poemas de Bandeira que serão analisados no próximo capítulo deste trabalho e que tensionam essas contradições brasileiras na própria forma do poema e revelam sutilmente essa violência da escravidão ou da exclusão de classes, criando, para isso, algo harmônico ou íntimo, que atrai, cordialmente, o leitor.

Além disso, a cordialidade, para Sérgio Buarque de Holanda, não é estática e não deve ser entendida como um conceito absoluto. É importante que, para Buarque, o "homem cordial" tenderia a uma dissolução que aconteceria com o processo de urbanização, seria algo superável. Realmente não é um conceito absoluto, é uma noção abstrata, mas que, diferente da perspectiva de Sério Buarque, a cordialidade não desaparece, ainda temos padrões de comportamento cordiais que destacam a noção como um momento constitutivo da modernização brasileira: o passado permanece como elemento constitutivo do presente.

Aqui é importante considerar que cordialidade se faz presente na sociedade do século XX e, como veremos, apresenta-se também como dilema estético e como problematização da vida intelectual do país da década de 20 e 30, contexto que, como vimos, situa-se a obra de Manuel Bandeira aqui estudada.

\subsection{A cordialidade, a literatura e o movimento modernista}

Pensar a problemática da cordialidade articulada a discussões relacionadas à produção literária brasileira e latino-americana, é pensar, além do contexto intelectual, uma arte e suas raízes na matéria social brasileira. Refletindo, não mecanicamente, a sociedade da qual faz parte, pode, muitas vezes, acompanhar o discurso sociológico, mas é capaz de prover o entendimento de uma totalidade indisponível na imediaticidade da vida social. É assim que os dilemas estéticos se apresentam como dilemas históricos e que a cordialidade pode ser produtiva na discussão de problemas literários. 
Nesse sentido, insere-se a percepção crítica do próprio Sérgio Buarque de Holanda, já que os seus textos de crítica literária, mesmo antes 1930, acompanham algumas ideias de Raízes do Brasil, é o que mostra Antonio Arnoni Prado (2015) em recente obra, intitulada Dois letrados e o Brasil nação, que analisa a obra crítica de Sérgio Buarque de Holanda em contraste com a de Oliveira Lima:

E, podemos notar, no ânimo do rapaz [Sérgio Buarque de Holanda] que escrevia naquele momento anterior ao Modernismo, como era forte a discordância com os críticos acomodados à possibilidade de "poetizar uma raça cuja vida não tem poesia", tanto quanto a própria consciência de buscar nos intelectuais latino-americanos os sinais concretos de um passado comum que fizesse amadurecer a integração da ruptura para muito além dos personalismos que caracterizam nossas diferentes culturas e que depois aparecem, tão bem formulados, em Raizes do Brasil. (PRADO, p. 254, 2015).

Antonio Arnoni Prado (2015) analisa o percurso dos estudos críticos de Buarque. E, ao contextualizá-los no tempo histórico, apresenta o crítico como parte de uma geração que buscava uma independência artística e uma expressão cultural não revelada do Brasil. Arnoni Prado comenta aproximações e distanciamentos de Buarque com movimento modernista e principalmente uma recusa a artificialismos persistentes na literatura brasileira ao falar do país.

É interessante ressaltar que é relacionado a essa recusa a artificialismos que Sérgio Buarque elogia a poética de Manuel Bandeira que fala do Brasil, pois ela exprime o que há de mais cotidiano e, assim, de mais profundo. Esse comentário, assim como outros que contém o que Sérgio Buarque diz sobre Bandeira em suas críticas literárias, está presente no capítulo 1 deste trabalho, mas é válido, para visualização da reflexão proposta, transcrevê-lo novamente aqui:

As coisas triviais, quotidianas, podem valer mais para êle do que as realidades vistosas. E isso não por simplismo voluntário, mas certamente pela convicção de que há nelas mais importância, maior interesse poético. Foi essa convicção que êle próprio chegou a sugerir em uma das suas Crônicas da Província do Brasil, quando criticou, com razão, certa atitude literária de nossos escritores: 'Falamos de coisas brasileiras como se as estivéssemos vendo pela primeira vez, de sorte que em vez de exprimirmos o que há nelas de mais profundo, isto é, de mais quotidiano, ficamos nas exterioridades puramente sensuais.' (HOLANDA, 1944, p. 33).

A tarefa crítica literária de Sérgio Buarque se relaciona com

encarar a produção literária brasileira com o empenho de confirmar que a literatura, como a arte de modo em geral, sendo "discriminação e seleção", é 
a única instância capaz de discernir com precisão os valores humanos no quadro até então mal estudado de "inclusão e confusão" a que se resume a vida brasileira. Com o objetivo de compreender não só os critérios estritamente formais, mas toda a apreensão da realidade através dos elementos inefáveis que ela possa despertar. (PRADO, 2015, p. 356).

Nesse sentido, Arnoni Prado (2015) critica estudos como os de Oliveira Lima que, pensando em aspectos europeus, não integra a nossa literatura no seu contexto de "descontinuidade e de crise".

Observamos, a partir de Arnoni Prado (2015), no percurso da crítica literária buarquiana a percepção, com um olhar crítico sobre o passado, do contexto da realidade histórica brasileira, sobretudo em suas crises e rupturas, entre elas a que envolve o espaço rural e urbano, central em nossa literatura e que revela o problema da cordialidade.

Essa relação literatura e cordialidade, como também sublinha Jerônimo Teixeira (2005) em Drummond Cordial, está em vários textos de críticos brasileiros de maneira implícita, por exemplo: acompanhando a dialética do rural e do urbano ou a lógica do favor de ensaios de Antonio Candido e Roberto Schwarz. E também aparece de forma explícita, como em Literatura e cordialidade, obra do professor João Cezar de Castro Rocha, que, conforme Jerônimo Teixeira:

Mesmo centrado em um episódio cultural do século XIX - a polêmica levantada por José de Alencar em torno do poema A confederação dos tamoios, de Gonçalves de Magalhães -, oferece abundantes exemplos da persistência da cordialidade na cultura brasileira ao longo do século XX. (TEIXEIRA, p. 35, 2005).

Esse estudo de Jerônimo Teixeira (2005), Drummond Cordial, é ele mesmo um exemplo dessa relação sendo tratada de forma explícita e mostra a cordialidade não como algo estático, mas dinâmico, na voz poética de um dos maiores poetas brasileiros. Mas também já indica, como foi abordado no capítulo 1, a relação cordialidade e a poética de Manuel Bandeira.

\subsection{Um poeta moderno brasileiro e a cordialidade}

Drummond Cordial, de Jerônimo Teixeira, como abordado no capítulo 1 deste trabalho, analisa a relação cordialidade e literatura sem negar as complexidades da conexão entre os temas e discute o modo como a obra de Drummond sugere a cordialidade, a partir da problematização da representação dos antagonismos relacionados a nova vida urbana mecanizada e a decadência de um mundo rural perdido: 
Se é verdade que tais antagonismos históricos retomam à imanência da obra de arte como problemas formais - se essa dialética fez-se efetiva na obra de Drummond, então seria possível falar em uma forma cordial? Isso é relativo. O problema é complexo demais para que se estabeleça um receituário acabado do que é ou não "cordial” em poesia. (TEIXEIRA, 2005, p. 47).

Em tal obra, análises permitem ver como os poemas sugerem a categoria social do "homem cordial", na medida em que exploram a expressão de algo pessoal e individual. Por exemplo, o crítico analisa os versos "Tive ouro, tive gado, tive fazendas. / Hoje sou funcionário público, / Itabira é apenas uma fotografia na parede. / Mas como dói! ” (ANDRADE, 1992, p. 57), em que está presente todo um complexo histórico de decadência do patriarcado rural e o crescimento de uma urbanização, entretanto tudo é marcado pelo poeta falando de uma dor individual. A partir dessa dialética, Teixeira (2005) procura afirmar que a cordialidade é um dos problemas centrais da poesia drummondiana.

É o que se faz presente na análise comparativa de dois poemas de Drummond: "Canção amiga", que traz algo de esperança e de simplicidade, e "Oficina irritada", que traz amargura e violência. Para o crítico, os dois poemas podem ser lidos como relacionados a uma crise do verso e a um sujeito sitiado pela urbanização crescente, tal como é o "homem cordial".

Teixeira (2005) elenca, a partir desses poemas, algumas características cordiais presentes na forma textual, o que está mais claro em "Canção amiga". Um exemplo é a linguagem política transformável em algo mais doméstico, o que se explica com o verbo acordar com seu sentido politizante (acordar de uma alienação) levado ao seu sentido denotativo da relação doméstica entre mãe e criança: "Eu preparo uma canção/ que faça acordar os homens/ e adormecer as crianças”. Para Teixeira (2005), está presente a invasão do público pelo privado.

A rua, um espaço público, é apresentada como algo que passa a ser um espaço cordial e particular de encontro de velhos amigos: "Caminho por uma rua/ que passa em muitos países./ Se não me vêem, eu vejo/ e saúdo os velhos amigos.”. Além disso, nesse poema, a sintaxe e o léxico são simples, há um vocabulário familiar e afetivo, o próprio adjetivo "amiga" do título denota isso. Entre outros aspectos analisados por Teixeira (2005) na cuidadosa análise comparativa dos dois poemas, a qual usamos aqui apenas como exemplo de tratamento do tema da cordialidade num poeta modernista.

Há uma oposição entre "Canção amiga" e "Oficina irritada", mas o vetor histórico é o mesmo. De acordo com Teixeira (2005), no primeiro, o eu-lírico está jogado na rua e é ignorado, isso resulta em um isolamento que o segundo poema já é obrigado a enfrentar, sendo que o "homem cordial" teme a solidão. O poema busca criar uma dureza ("eu quero compor um 
soneto duro"), e o "eu quero" desconsidera o que não faz parte desse querer, expressando a solidão, a intenção de "Canção amiga" é diferente: “eu preparo...”, já faz, e, portanto, não é só o querer da solidão interior.

"Oficina irritada" explicita ainda um tom amargurado e como Drummond, ao contrário de Bandeira, não procura fazer algo agradável paro o leitor, algo que Teixeira (2005) aponta ao comentar do aspecto seco desses versos drummondianos. Se, como foi visto no capítulo 1 deste estudo, Bandeira acolhe o leitor cordialmente, em Drummond, na maioria das vezes, tem-se algo mais irritado que repele o leitor.

Mas esse soneto duro é, como é percebido pelas metáforas "tiro no muro", "cão mijando no caos", passageiro. Há também uma tendência abstrata e um hermetismo ("eu quero pintar um soneto escuro, seco, abafado, difícil de ler”), mas marcados pela ambiguidade ("ao mesmo tempo saiba ser, não ser”). E há no final um “claro enigma”. Dessa forma que para o crítico: "a própria noção de "claro enigma" talvez seja uma forma de conciliação cordial: uma abstração que ainda se deixa decifrar". (TEIXEIRA, 2005, p. 68).

Dessa forma, Teixeira (2005) analisa que, nesse poema, a cordialidade sobrevive mesmo que em negativo, mesmo com a presença da solidão e da abstração, há uma conciliação cordial. $\mathrm{Na}$ sociedade, formas de representação social fixadas com a colonização não desaparecem tão rapidamente com o avanço da urbanização.

Como nesses exemplos, a obra de Jerônimo Teixeira (2005) mostra antagonismos históricos e apresenta a cordialidade como problema formal, Teixeira (2005) elenca diretrizes para as leituras dos poemas, tais como considerar a tradição brasileira de fazer conciliações brutais, o afeto da amizade como critério de avaliação literária (comum no modernismo, como veremos) e a tentativa cordial de tornar íntimo.

A partir disso, Teixeira (2005) se ocupa de poemas que mostram a evolução dessas diretrizes cordiais na poesia drummondiana, ou seja, evidenciam o fato de que o "homem cordial" é um complexo social mutável, que, com o tempo, tende à dissolução. Algo já muito mais visível em Drummond do que em Bandeira, como analisa o crítico ao afirmar que, em Drummond, a cordialidade atinge seu limite absoluto, já Manuel Bandeira insiste em fixar formas históricas evanescentes.

Um exemplo da dissolução está no esgotamento do uso do diminutivo nos livros de Drummond:

Para Sérgio Buarque, o diminutivo era o expediente linguístico mais típico do "homem cordial": pela terminação "inho", aproximamos afetivamente o que está distante. Alguma poesia é o livro em que Drummond mais emprega o 
diminutivo, com ocorrência em oito poemas, número que cai para dois em Brejo das almas e zero em Sentimento do mundo e José. (TEIXEIRA, p. 157, 2005).

Na poética de Manuel Bandeira, o uso de diminutivos se apresenta de forma muito forte em Libertinagem, em dezessete poemas, inclusive do poema em francês "Chambre Vide" ("petit chat").

Essa ocorrência do diminutivo na obra publicada em 1930 é significativa, porque, em um período marcado pelo processo de modernização, o uso de um recurso que traz uma atmosfera provinciana e afetiva assinala a contradição desse contexto de produção. Além disso, sabe-se que o diminutivo se apresenta como recurso formal importante, conforme já foi comentado no capítulo 1 deste trabalho, com suas acepções irônicas, afetivas etc (por exemplo, no poema "Belém do Pará", "sobradinhos coloniais tão bonitinhos" não se relaciona com o tamanho, mas carrega afeto e ironia). O que precisa ser investigado, assim como o alto número de diminutivos em Libertinagem.

Além do esgotamento do diminutivo em Drummond mostrar limites em relação à cordialidade, outro exemplo que marcaria esses limites analisados em Drummond Cordial é um rompimento presente no conhecido poema "Quadrilha":

O relato do destino de cada personagem tem um certo sabor de fofoca, o poeta colocando em dia a conversa com o leitor. A expressão "ficou para tia", cheia de maldade coloquial, reforça o tem de mexerico. Mas então surge J. Pinto Fernandes, que não havia entrado na história. O círculo abre-se para um estranho. Está rompido o pacto cordial. (TEIXEIRA, 2005, p. 157).

A obra crítica destaca também poemas que abordam a ficção relacionada à família do poeta. Há, nessa temática, além de algo fundamental ao "homem cordial" (a família), um percurso percebido por Teixeira (2005), do passado (fazenda, casa paterna, Rio de Janeiro) ao presente (rua, apartamento, Itabira) que evidencia fatores tipicamente cordiais e a perda, na vida moderna, deles. O que também se aproxima de uma relação existente em Manuel Bandeira, entre Rio de Janeiro e Recife, mas que mais atesta a permanência de fatores cordiais e passados na modernidade. Além disso, há, em vários momentos, nos textos de Manuel Bandeira, a família, em especial a casa do avô em Recife, atravessada por aspectos do passado.

Em um dos poemas de Drummond relacionados à família, como "No país dos Andrades", Teixeira (2005) já enxerga o título como uma síntese da autossuficiência da família rural, permeada de valores do passado. Porém, o crítico afirma que o poema mostra esse mundo em decadência na figura das formigas ("indago um objeto desaparecido há trinta anos, que não 
sei se furtaram, mas só acho formigas"). E, "tonto, agudo e suspeitoso" diante do mundo mais impessoal que aparece, o eu-lírico anuncia uma libertação da tradição, mas há um limite nisso: "(viajarei)" que marca essa libertação está entre parênteses, no futuro e acompanhado de “cobertor de meu pai”, está aprisionado por ele. De acordo com a análise de Teixeira (2005), o poema mostra, então, a ambiguidade entre a dissolução e a resistência das forças sociais da cordialidade.

Dessa forma, Drummond Cordial é um estudo que mostra o espaço do poema relacionado à contradição presente na história, ou seja, traz o choque contraditório da cordialidade no Brasil republicano e urbanizado: "O poeta rearranjou os choques históricos a que ele mesmo estava submetido em um novo campo de tensões - o poema.” (TEIXEIRA, p. $69,2005)$.

Essa obra crítica apresenta, ainda, comentários sobre a relação sistema intelectual brasileiro e cultura auditiva. Tal cultura, para Teixeira (2005), é derivada da cordialidade, pois se relaciona à aversão à impessoalidade, afirmada por Sérgio Buarque como traço específico do brasileiro, que conduz à incapacidade de abstração.

A característica diletante do "homem cordial" em sua cultura auditiva está também na relação literatura e cordialidade, Jerônimo Teixeira conclui que "em uma sociedade cordial e em uma cultura auditiva, o diletantismo assombra as letras." (TEIXEIRA, 2005, p. 39) ou ainda que "na sociedade regida pela cordialidade, o diletantismo torna-se o princípio da vida cultural" (TEIXEIRA, 2005, p. 39).

Diante disso, o crítico afirma que Drummond não era um diletante, entretanto, a sua produção que lhe conferiu mais popularidade foram suas crônicas, gênero importante dessa cultura auditiva. Além disso, Teixeira (2005) cita que Luiz Costa Lima considera Durmmond como vítima de um país cuja cultura auditiva impede o cultivo da "reflexão".

Mas Jerônimo Teixeira (2005) desconfia dessa ideia de vítima e, considerando a poesia de Alguma poesia (1930) até Lição das coisas (1962), vê que:

Drummond soube fazer uma poesia surpreendente reflexiva. Que isso nunca tenha sido acompanhada por uma produção teórica consistente motiva uma certa perplexidade na crítica. (...) Pignatari descobre em Drummond a confirmação da "famosa tirada de Mallarme a Degas: poesia se faz com palavras, não com ideias. No período aqui em estudo, as "palavras" de Drummond conseguiram de fato ultrapassar não só suas próprias ideias, mas também o sistema cultural que as gestou. Esse pulo do gato da poesia é um mistério para a raposa invejosa da crítica (TEIXEIRA, 2005, p. 41) 
A poesia de Drummond, por meio do trabalho poético com as palavras, ultrapassa, mesmo o contendo, esse sistema cultural assombrado por um caráter diletante e pela cultura auditiva. Teixeira (2005) se propõe a entender esse pulo da literatura a partir da relação poesia e história.

É típico dessa cultura brasileira uma dignidade maior ao trabalho intelectual e ao ornamento, uma apreciação ao falar difícil e bonito. De forma dialética, a lírica bandeiriana moderna, contrária a uma sociedade que admira o ornamento e uma eloquência, dá importância as palavras simples de todo dia. Em várias crônicas, ele defende o estilo simples, como em "O "nosso" Saint-Hilaire", que admira a simplicidade e a clareza de sua obra e coloca que: "Entre nós é frequente fazer-se o contrário: escrever de tal maneira, com tão ridículas imagens e tão falsa profundidade que as coisas de simples bom senso viram transcendências. Precisamos ler muito Auguste Saint-Hilaire.” (BANDEIRA, 2005, p. 202).

Bandeira não era um diletante, era alguém muito consciente da técnica e que passou por um longo trabalho poético com as palavras. Assim como outras características de sua poesia, apontadas no capítulo 1, a ideia de alumbramento, que pode se associar a um diletante, é ambivalente, serve para aproximar um leitor e faz parte dessa consciência da técnica, sendo algo que Manuel Bandeira diz fazer parte da sua poesia constantemente em Itinerário de Pasárgada: "Na minha experiência pessoal fui verificando que o meu esforço consciente só resultava em insatisfação, ao passo que o que me saía do subconsciente, uma espécie de transe ou alumbramento, tinha ao menos a virtude de me deixar aliviado das minhas angústias" (BANDEIRA, 2012, p. 40). Dessa forma, Bandeira, que, de forma alguma, era um diletante, ultrapassa o sistema cultural assombrado por esse caráter e constrói produções reflexivas.

A partir da contradição do alumbramento e do trabalho com as palavras, Bandeira chega, em Intinerário de Pasárgada, também à lição de Marllarmé, presente na citação citada sobre Drummond: "Em literatura a poesia está nas palavras, se faz com palavras e não com ideias e sentimentos, muito embora, bem entendido, seja pela força do sentimento ou pela tensão do espírito que acodem ao poetas as combinações de palavras onde há carga de poesia." (BANDERIA, 2005, p. 202). A simplicidade formal das palavras dos poemas de Bandeira e o uso de palavras de todo o dia, que pressupõe não apenas um alumbramento, mas um trabalho com as palavras, ultrapassam as características de um sistema cultural ligado às aparências e ao ornamento. Dialeticamente, é essa simplicidade que gera reflexão a partir da complexidade oculta e revelada nessas palavras simples. 


\subsection{Aproximações: $o$ favor e a malandragem}

Considerando o contexto da dinâmica da história brasileira, há tensões que se manifestam na literatura como contradição estética. Na tradição crítica brasileira, há percepções que se alinham à preocupação da cordialidade em Raízes do Brasil, como a "malandragem" e a "lógica do favor".

Em relação às noções de favor e de dialética da malandragem, presentes nos textos "Dialética da malandragem" (Antonio Candido) e Um mestre na periferia do capitalismo (Roberto Schwarz), Jerônimo Teixeira (2005) traz uma nota fundamental, ressalvando que não são conceitos sinônimos de cordialidade, mas que podem existir, no "homem cordial", aspectos do malandro, além de caracterizar o favor como um expediente cordial. A partir dessas observações, Teixeira (2005) problematiza as instituições brasileiras, assim como Sérgio Buarque:

Deve-se ressaltar que "homem cordial" e "malandro" não são sinônimos. Um malandro como Leonardo pode muito bem recorrer a expedientes cordiais particularmente o "favor" e a "indicação" de protetores abandonados - para obter vantagens. Mas a cordialidade não se resume a esses expedientes. (...) Ela também tem um papel determinante na "ineficiência das instituições públicas". O "favor" e o "pistolão", o sequestro da máquina estatal para fins particularistas - nenhuma dessas práticas, que inserem razões privadas na esfera do público, são para-institucionais. (TEIXEIRA, 2005, p. 37).

Conforme Antonio Arnoni Prado (1998), o malandro é “originário dos traços mais profundos da nossa realidade social e representativo da ação ambígua que tolera a circulação livre por entre as esferas da ordem e da desordem". (PRADO, 1998, p. 75). O professor afirma também que Schwarz, na análise das Memórias Póstumas de Brás Cubas, “acaba fixando o 'contraste entre a face pública [do sistema], marcada pelo ar da Corte e de modernidade, e os traços em que se vê ou adivinha a Colônia”. (PRADO, 1998, p. 76).

Pensando com Antonio Prado (1998), ganha representação literária a ambiguidade depois indicada por Sérgio Buarque em relação às instituições brasileiras, a qual se encontra nos valores normais ao cotidiano brasileiro que contradizem as ideias europeias modernas e o capitalismo.

Nesse sentido, faz-se importante a reflexão acerca do ensaio "As ideias fora do lugar", em que Roberto Schwarz (1987) aborda as contradições da escravidão em relação às ideias do liberalismo europeu. Ideias que marcaram o século XIX no Brasil mesmo que impraticáveis 
aqui. Essa contradição fundamental denuncia que se fazia "o oposto exato do que era moderno fazer" (SCHWARZ, 1987, p. 62). Assim também é com o "favor".

Considerando as três classes da sociedade brasileira da época em questão - o proprietário, o escravo e o homem livre, Schwarz volta sua atenção para os homens livres, que, na verdade, eram dependentes do "favor". Por meio desse mecanismo, as classes da sociedade brasileira se reproduzem, sendo esta, para o crítico, "a nossa mediação quase universal" (SCHWARZ, 1987, p. 62).

Schwarz (1967) argumenta que o favor era mais simpático que a escravidão - realidade que os escritores muitas vezes tentavam esconder -, ainda que também contrário aos princípios da civilização burguesa europeia que adotávamos, e disfarçava a violência da esfera de produção.

A oposição de uma ideia adotada, que envolvia burocracia, justiça e mérito, e da realidade, envolvendo favor, mérito ao parentesco, privilégio, está em várias esferas da sociedade, assim como no plano das instituições. Nossa realidade convivia falsamente com as ideias burguesas que, mesmo na Europa, não deixavam de ser contraditórias, encobrindo, assim, a exploração do trabalho e os antagonismos de classe, o que mostra a fragilidade dos valores liberais. Isso, conforme Schwarz (1967), resulta para a literatura um oco dento do oco, um desconcerto, dualismos e contradições que o Modernismo considera (e, nas palavras do crítico, algo que o Modernismo nos ensina a considerar, assim como a Economia Política e o Tropicalismo).

Machado de Assis, na nossa tradição literária, foi o mestre em relação às contradições brasileiras, como mostra a ironia presente no exemplo que Schwarz cita de Quincas Borba, em que Rubião não fica à vontade ao trocar seu escravo por um cozinheiro francês. Um quadro complexo era o que o atraso histórico impunha à literatura realista.

Com essas considerações, é coerente afirmar que o nosso particular, marcado pelo colonialismo e pela reprodução e dependência de ideias europeias, revela também a história universal, sendo assim, matéria também e problema literário: "o tique-taque das conversões e reconversões de liberalismo e favor é o efeito local e opaco de um mecanismo planetário. Ora a gravitação cotidiana das ideias e das perspectivas práticas é a matéria imediata e natural da literatura." (SCHWARZ, 1967, p. 82).

Assim, aprendemos com o crítico que, mesmo sem ser a intenção do autor, a história mundial em resultados locais passa para a literatura, a qual tem, então, uma matéria em dinâmica com o processo histórico. O que está de forma consequente em Machado de Assis, 
por exemplo, e em obras que não negam as contradições do país. E está também em Manuel Bandeira, conforme se quer mostrar neste trabalho.

É considerando essas nossas contradições que, em "Dialética da malandragem", Antonio Candido (1970) afasta Memórias de um sargento de milícias do romance picaresco à maneira dos espanhóis e explica a figura do malandro. Dentre outras diferenciações, conclui que, diferente dos narradores picarescos, Leonardo não teve o choque áspero com a realidade que o tornou pícaro, mas "nasce malandro feito, como se tratasse de uma qualidade essencial, não um atributo adquirido por forças das circunstâncias". (CANDIDO, 1970, p. 67).

Ao longo do artigo de Antonio Candido, o malandro do romance de Manuel Antônio de Almeida é pensando em torno de algumas características tanto temáticas como formais: um ofício manual é como ofensa para ele; o malandro desse romance é risonho, espontâneo; parece ter um destino que motiva a conduta de forma forte por meio da caracterização pelo enredo e um esvaziamento de lastro psicológico - marcada pela narração em terceira pessoa; vive ao sabor da sorte, mas nada aprende; não procura agradar os superiores; a astúcia pela astúcia; etc.

Candido (1970), a partir do levantamento de diferenças e semelhanças, afasta o personagem da tradição picaresca espanhola e mostra uma tradição brasileira, sendo Leonardo o primeiro grande malandro que entra na novelística nacional, o que vai estar, depois, em Macunaíma como símbolo, mostrando a persistência dessa figura no século XX.

Memórias de um sargento de milícias é, conforme Antonio Candido (1970), além do único romance conhecido na literatura brasileira do século XIX que não exprime visão da classe dominante por não manifestar atitudes ideológicas predominantes no período - indianismo, nacionalismo etc, baseia-se na intuição da dinâmica social do Brasil do século XIX e se projeta no tempo. Há a dialética da ordem e da desordem, como aspectos equivalentes em todo o romance e funciona com uma correlação da sociedade: "No Brasil, nunca os grupos ou indivíduos tiveram a obsessão da ordem senão como princípio abstrato, nem a liberdade senão como capricho". (CANDIDO, 1970, p. 72).

Dessa forma, a figura do malandro, um anti-herói nacional, é um problema formal brasileiro na medida em que é um problema histórico, assim como as categorias do favor e a da cordialidade presentes nas relações brasileiras que são problemas formais também na obra bandeiriana que se presente analisar.

\subsection{Relações cordiais no Modernismo}


Silvana Moreli Vicente Dias (2013), no artigo "Matizes da cordialidade: a correspondência de escritores e inflexões dos debates do modernismo brasileiro", afirma que o conceito de cordialidade tem sido indiscriminadamente utilizado em ambiente acadêmico. Mas ela aponta que a ambiguidade está na própria origem ensaística e, assim, que a expressão ainda pode ser produtiva, "principalmente se articulada com a produção literária e intelectual dos anos 1920 e 1930, quando ainda não havia uma tradição acadêmica no país” (DIAS, 2013, p. 364).

A relação cordialidade e literatura também se encontra no contexto cultural dos intelectuais brasileiros e no de discussões literárias. Silvana Dias (2013) objetiva, no artigo citado, discutir a possibilidade de ler as cartas trocadas por Gilberto Freyre e Manuel Bandeira com base na cordialidade, assim como atenta para outras cartas trocadas no contexto do modernismo, articulando o conceito e o movimento, enriquecendo a reflexão da vida literária e social no Brasil de 20 e 30.

Porém, é necessário destacar que a análise é feita apoiada na perspectiva de Gilberto Freyre em torno da cordialidade, ou seja, é apoiada em uma perspectiva mais harmônica, se comparada à de Sérgio Buarque, para as relações de intimidade.

A estudiosa analisa uma predisposição cordial no modernismo brasileiro tendo como pano de fundo um contexto histórico de processo de modernização problemática que influenciou o trabalho artístico em um período "que sentia os efeitos de uma urbanização acelerada a se chocar com a herança rural e escravocrata, lutando conta a herança colonial" (DIAS, 2013, p. 364). Essa contextualização é fundamental e problematiza a questão da cordialidade na literatura do período.

Há, com esse choque, uma "articulação paradoxal entre os avanços da modernidade e o pendor localista” (DIAS, 2013, p. 356). Algo que está também nos modernistas paulistas com as viagens relacionados à redescoberta do Brasil interior, envolvendo técnica moderna e desejo de pertencimento. Tem-se, assim, uma técnica que influenciou a nova linguagem modernista, como em Serafim Ponte Grande de Oswald de Andrade, e que em conjunto com a cordialidade traduz, para a estudiosa, "o processo tortuoso de modernização nos campos artísticos e intelectual que se acelera no país dos anos 1920 e 1930” (DIAS, 2013, p. 356).

A partir desse contexto e considerando as cartas trocadas por Manuel Bandeira e Freyre, a autora mostra como a forma dessas cartas já apresenta, através de uma informalidade e do tom de conversa, uma associação com a cordialidade. Percebe-se também o caráter de favores e impressões amigas entre os intelectuais modernistas. Somado a isso, ela argumenta que: 
Amizade e trabalho artístico são duas coisas que se mesclam, muito generosamente, num ambiente cordial, tornando mais intricada a condição de autonomia da arte em contexto nacional. Assim, a cordialidade parece ser uma marca fundamental da sociabilidade dessa geração de escritores e intelectuais, que deixam seu rastro nas próprias formas de composição da época. (DIAS, 2013, p. 356).

Vale acrescentar que a obra em prosa de Manuel Bandeira traz indicações desse ambiente cordial. Em Itinerário de Pasárgada, evidenciam-se os laços de afeto como importantes na escrita de poemas e na relação de Manuel Bandeira com o movimento modernista, como foi citado também no capítulo 1 deste trabalho:

(...) Pouco me deve o movimento; o que devo a ele é enorme. Não só por intermédio dele vim a tomar conhecimento da arte de vanguarda na Europa (...), como me vi sempre estimulado pela aura de simpatia que me vinha do grupo paulista. Para completar (e de certo modo contrabalançar) essa influência havia os amigos do Rio, amigos que, a partir de Ribeiro Couto, fui fazendo em cadeia: Jaime Ovalle, Rodrigo M. F. de Andrade, Dante Milano, Osvaldo Costa, Sérgio Buarque de Holanda, Prudente de Morais Neto. Lista a que devo juntar, depois de 1925, o nome de Gilberto Freyre, cuja sensibilidade de tão pernambucana muito concorreu para me reconduzir ao amor da província (...). O Morro do Curvelo, todos esses amigos e, naturalmente, outros laços de afeto - eis o clima dentro do qual compus os livros de versos O Ritmo Dissoluto, Libertinagem, grande parte de Estrela da Manhã, e o livro de Crônicas da Província do Brasil. (BANDEIRA, 2012, p. 90; grifo nosso)

O discurso é ficcional, assim, apesar de toda a influência de Manuel Bandeira, com o verso livre e outros fatores, que o ligam ao movimento modernista, é significativo simplificar a sua associação ao movimento essencialmente a critérios de amizade.

Considerando a cordialidade como um aspecto que envolve uma sociabilidade brasileira, Silvana Dias (2013) observa, principalmente por meio das correspondências, os contatos com grupos de intelectuais citados e uma forma mais informal com marcas de oralidade, além de elas conterem muito da vida social da época e da vida pessoal dos autores. Dias (2013) levanta também a hipótese de que essa sociabilidade deixou marcas na escrita modernista.

A oralidade é característica fundamental não só da epistolografia cordial comentada por Dias (2013), mas textos literários modernistas, que se aproximam, muitas vezes, de uma conversa informal com amigos. Faz-se frágil, também no contexto dos intelectuais do Modernismo, a distinção público e privado.

Dessa forma, a cordialidade é parte do Modernismo, não apenas como valor cultural positivo e harmônico de um povo que gosta de conversar, mas carregando problematizações e 
relações políticas e sociais de uma sociedade desigual imersa em um processo de modernização problemática.

João César de Castro Rocha (2005), em O exílio do homem cordial, confere uma perspectiva negativa às relações cordiais dos intelectuais brasileiros. Pois a cordialidade, nesse contexto, implica em relações pessoais sendo determinantes ao elogio das obras, na lógica do favor, na preferência pela produção dos amigos, o que prejudica o universo de leitura, a discussão e a oposição de ideias. Essa abordagem denuncia um personalismo cheio de preferências pessoas que prejudica o olhar crítico:

O intelectual à brasileira ainda vive à sombra das relações pessoais e da reciprocidade de elogios, assim como a esferas da vida nacional a lógica do favor continua sendo a moeda de troca determinante. Em tal cenário, sem dúvida, a crítica será sempre a "indesejada das gentes", pois, em lugar da análise de uma obra ou da discussão de uma ideia, o que se espera é a confirmação do valor do amigo, se possível de sua genialidade. O exercício crítico, portanto, literalmente representaria a morte de uma sociabilidade fundada no compadrio, aí incluiria a própria experiência intelectual. (ROCHA, 2005, p. 14).

Formou-se, dessa forma, com o elogio ao amigo e o ataque ao inimigo, modelos dicotômicos em polêmicas, como cariocas e paulistas, modernistas e regionalistas, a tensão intelectual de Gilberto Freyre e os paulistas no mesmo esforço de compreender a formação da sociedade brasileira com perspectivas diferentes, em torno de uma disputa pessoal e regionalista, que se trata muito mais, conforme João César Rocha (2005) tenta demostrar, de uma "angústia de influência", a qual, Manuel Bandeira não deixa de fazer parte, como mostra as cartas trocadas com Mário de Andrade e com Gilberto Freyre e a tentativa de estabelecer uma ponte entre os seus dois amigos contrários.

No Modernismo, o fato das relações pessoais como sombra das intelectuais também se relaciona, segundo João César Rocha (2005), às vanguardas em um enfrentamento à usual recusa do público, criando-se um público restrito formado por contatos particulares predispostos a aceitar essa arte de vanguarda. Nas palavras do crítico:

O paroxismo de tal tendência encontra-se na criação de autêntico oxímoro: o Museu da arte moderna. Essa situação favorece a aproximação das práticas do homem cordial com as estratégias vanguardistas, pois (...) ocorre o predomínio da lógica afetiva e da dinâmica do favor, elementos definidores da esfera privada. (ROCHA, 2005, p. 79). 
Assim, a permanência de uma herança patriarcal não se faz só na vida política brasileira, mas se faz presente no sistema intelectual, que deveria ser um meio de definir "uma crítica rigorosa daquela tradição" (ROCHA, 2005, p. 14).

\subsection{Considerações finais}

Como foi visto, a cordialidade é um conceito ambivalente e paradoxal, porque carrega o caráter de afetividade, algo do senso comum do brasileiro hospitaleiro, da simpatia, e, dialeticamente, carrega uma violência, e a perpetuação dela, que compreende diferenças de classes sociais e a dominação das camadas superiores ao longo da história, assim como os fundamentos personalistas da vida social brasileira. Além disso, o conceito gerou muitas interpretações e discussões, principalmente em relação aos que ligam a palavra apenas a algo bom, o que é um equívoco.

A cordialidade é um conceito que interpreta padrões de comportamento associados ao modo que a sociedade brasileira se organiza, é marca da nossa herança colonial na modernidade. Como problema local e parte da dinâmica do processo histórico, torna-se matéria literária, como veremos, e é percebida também como um problema artístico para o Modernismo, pois deixa marcas na escrita modernista e se articula à discussão em torno da preocupação de se pensar o país, preocupação essencial do pensamento artístico e intelectual nos decênios de 1920 e 1930.

Há, em nossa literatura, íntima relação com a investigação de ordem histórica e social, que, muitas vezes, estão como categorias literárias evidenciadas no interior das obras, como foi analisado por Antonio Candido em Memórias de um sargento de milícia, por Roberto Schwarz como analista de Machado de Assis e por Jerônimo Teixeira em relação à poética de Drummond, para citar alguns exemplos.

Como vimos, na obra de Manuel Bandeira, muito significativa dentro movimento modernista, está presente a preocupação em redescobrir a nação. É significativa a afirmação de Júlio Castañon Guimarães (2006), no Posfácio de Crônicas da província do Brasil, sobre a existência da relação da obra bandeiriana com as obras de estudo sobre o Brasil mencionadas neste capítulo:

As Crônicas da província do Brasil surgem no âmbito da publicação, quatro anos antes, em 1933, de Casa-grande \& senzala, de Gilberto Freyre, e um ano antes, em 1936, de Raízes do Brasil, de Sérgio Buarque de Holanda. Não é o caso de modo algum de aproximar destes livros o de Bandeira, que não constitui estudo sistemático nem tem a mesma abrangência e alcance. Mas se trata de chamar a atenção para o fato de que ele está inserido no âmbito de 
uma preocupação comum. (...). Encontra-se nas Crônicas da província do Brasil um empenho, se não exatamente de interpretação, pelo menos de conhecimento do Brasil. (GUIMARÃES, 2006, p. 248-249).

Para tanto, Guimarães cita indicações como a pesquisa local relacionada a viagens a cidades brasileiras ou a relação com Gilberto Freyre. Comenta também que a obra de Manuel Bandeira, em prosa e verso, inserida no contexto do Modernismo, traz a preocupação com as coisas brasileiras, muitas vezes com um aspecto documental, como em "Evocação do Recife", poema feito a pedido de Freyre. O crítico destaca ainda que, em vários momentos da obra de Bandeira, estão presentes o interior do Brasil e o passado colonial, destacando essa relação arte e problemáticas histórico-sociais.

Essa preocupação comum de conhecimento do Brasil indica a necessidade de analisar como a obra de Manuel Bandeira sugere e carrega contradições brasileiras ao interpretar a modernidade, estando inserida no contexto do modernismo, na tradição brasileira e no seu contexto histórico, e também dialogando com outros grandes nomes do mesmo período, entre eles Gilberto Freyre, Carlos Drummond de Andrade e Sérgio Buarque de Holanda.

Como vimos no capítulo 1, a fortuna crítica de Bandeira, mesmo que indiretamente, compreende a relação da sua obra com a questão do projeto nacional como problema temático e formal, assim como as construções em torno do processo violento de modernização do Brasil, que se configura, às vezes, como um saudosismo de valores tradicionais, exemplificados pelo grande número de poemas que se fala da infância, nos quais são significativos também a presença da família, os aspectos tradicionais de cidades ou estados brasileiros, como Recife ou Minas Gerais.

Para além do referencial desse empenho modernista de pensar o Brasil, a própria questão formal de uma voz lírica que considera um leitor e que é possível de ser identificada socialmente, além da criação de construções simbólicas em torno desse eu-poético, são indicativos de uma literatura que sugere a estruturação em algum nível da noção de cordialidade. Como isso se dá na forma dos textos será analisado no próximo capítulo a fim de perceber em que medida essa dimensão da vida brasileira se torna forma na obra.

Embora tenha sido feita a recuperação de estudos sistemáticos de uma rede de pensamentos relacionada à formação do Brasil, como Casa Grande \& Senzala e Raízes do Brasil, a intenção é propor o diálogo entre essa história e a literatura a partir da constatação que a própria obra de Manuel Bandeira propõe esse diálogo. O nacionalismo é uma marca temática nessa obra, mas se apresenta nos recursos formais e sugere a cordialidade. 
Por fim, é válido ressaltar que, apesar de Sérgio Buarque de Holanda, ser de certa forma otimista ao prever a superação do "homem cordial" com o desenvolvimento do processo de urbanização, cabe o questionamento em relação à permanência ainda hoje de algumas categorias cordiais em uma sociedade em que a relação do público com o privado parece sempre prejudicada. A matéria literária pode, então, ajudar a discutir também essa clara atualidade e as raízes coloniais ainda existentes em várias esferas da sociedade, em especial em relação à perpetuação de relações de classes, relação do dominado e daquele que domina. 


\section{Capítulo 3 - O singular da ideia modernista de nacionalismo na obra de Manuel Bandeira}

A partir da discussão do capítulo 1 deste trabalho, percebe-se a obra de Manuel Bandeira como partícipe do Modernismo e, por isso, engajada, mesmo que indiretamente, em discutir o Brasil. Interessa, neste capítulo, mostrar o modo singular que Bandeira expressa o nacionalismo e como sugere a noção de cordialidade, discutida no capítulo 2.

Neste capítulo, faz-se a análise de poemas e crônicas de Bandeira, recuperando alguns elementos dos capítulos anteriores. Os poemas analisados são: "Evocação do Recife", "Poema tirado de uma notícia de jornal", "Irene no céu" e "Não sei dançar"; as crônicas, "O que era Pernambuco de 1821", "A trinca do Curvelo", "Velório" e "Bahia". Os poemas, da obra Libertinagem, foram escritos entre 1924 a 1930 e publicados em 1930. Já as crônicas encontram-se na obra Crônicas da província do Brasil de 1937, e são textos publicados em jornais no fim da década de 20 e na década 30.

Todos os textos escolhidos, apesar de apresentarem várias diferenças formais e temáticas, trazem uma discussão, explícita ou implícita, sobre o Brasil que capta o movimento da experiência de passagem de um Brasil mais rural para um Brasil urbano, com o eu-lírico sendo parte disso. Sendo o contexto de publicação e de produção significativo para o critério de escolha dos textos, pois é um período que envolve uma renovação cultural articulada pela programática modernista e o choque de um processo de urbanização contaminada pela manutenção de esquemas sociais tradicionais.

Para a análise desses textos selecionados e a observância dessa discussão, este capítulo é dividido em dois tópicos principais. O primeiro, intitulado "As cidades de um país cordial" apresenta a temática da cidade como importante mediação na obra bandeiriana. O segundo, “Tão cordial”, explicita textos que sintetizam as contradições de um país e de uma época.

Assim, objetiva-se ver em que medida a dimensão da vida brasileira se torna forma na obra aqui estudada nesse momento de modernização, que carrega a contradição entre o progresso e o atraso, formativa em um país periférico.

\subsection{As cidades de um país cordial}


A obra de Manuel Bandeira possui várias imagens poéticas de cidades, vários títulos de crônicas e poemas possuem nomes de cidades ou estados do Brasil, como "Recife", "Bahia", "Evocação do Recife", "Ouro Preto", entre outros exemplos. "Vou-me embora pra Pasárgada", um dos seus poemas mais conhecidos e já citado neste trabalho, não deixa de ser também a criação de uma cidade por meio da poesia, criação feita por um poeta que pretendia se tornar arquiteto, mas, devido à tuberculose que o atingiu, não pode concretizar tal desejo.

Por causa desse problema de saúde, Manuel Bandeira viajou muito em busca de melhores climas. Mas foi com o Modernismo que as viagens se configuraram como meio de observação e produção de significados nacionais, relacionados com a redescoberta do Brasil empreendida por alguns modernistas.

Assim, a estética e as preocupações modernistas, além de um olhar crítico para a modernização das cidades brasileiras, como foi exemplificado em vários momentos ao longo deste trabalho, atestam a peculiaridade da representação dessas cidades na obra poética e em prosa, o que, então, é "associado às viagens como elemento propiciador de conhecimento [...] e também ao profundo envolvimento do autor com a produção cultural de sua época." (GUIMARÃES, 2006, p. 244).

Das várias cidades da obra de Manuel Bandeira, duas merecem uma atenção especial, Recife, a sua cidade natal, e Rio de Janeiro, a cidade em que morou boa parte da sua vida, na infância e na fase adulta, e onde viveu em várias áreas diferentes, Senador Furtado, Laranjeiras, N. Senhora de Copacabana, Leme, rua do Curvelo, Lapa, além de ser o lugar em que acompanhou, com um olhar crítico, a modernização do espaço urbano. As duas cidades, nesse contexto, evidenciam antíteses, como passado e presente, modernização e retrocesso.

Recife e Rio de Janeiro são duas cidades, que, na obra de Manuel Bandeira, mesmo com $\mathrm{o}$ processo de modernização na primeira metade do século $\mathrm{XX}$, aparecem com algo de provinciano e ligado ao passado, em uma permanência de aspectos interioranos que a obra insiste em salientar. Afinal, "este mesmo Rio de Janeiro de nós todos não guarda, até hoje, uma alma de província? O Brasil ainda é todo província. Deus o conserve assim por muitos anos" (BANDEIRA, 2006, p. 12).

Esse trecho da Advertência de Crônicas da Província do Brasil, por meio da ironia, atribui a característica de província mesmo para a capital, uma cidade mais afetada pelo processo de modernização na época, e deixa claro uma posição em relação a essa modernização que vai estar presente na obra de Bandeira, a qual se revela, muitas vezes, oposta às características da vida urbana do século XX, ou seja, à agitação, ao progresso e à racionalização 
das relações sociais característica do capitalismo, como veremos nos textos que serão discutidos aqui.

O processo de urbanização no Brasil atingiu primeiramente o Rio de Janeiro, que foi sede da coroa portuguesa e palco dos principais acontecimentos políticos desde então. Em relação a Recife, capital do estado de Pernambuco, apresenta-se mais fortemente, assim como outras cidades da Região Nordeste, marcas do passado colonial, um tempo áureo para os senhores de terra da região, quando a economia era voltada para o açúcar e os conhecidos engenhos do Nordeste. Como vimos no capítulo 1, o processo de modernização não se deu da mesma forma em todas as regiões, sendo que o Nordeste se encontrava à margem e tendente a esse arcaísmo, em contraste, por exemplo, com São Paulo, que já vivia problemas com a industrialização, além dos movimentos operários.

Há, na obra de Bandeira, um olhar crítico à modernização, uma recuperação de aspectos de um passado marcado por um patriarcado rural e uma negação das mudanças do espaço urbano, compartilhada por grupos que reagem frente à modernidade, grupos que Manuel Bandeira parece se identificar. Sendo o seu pai engenheiro que atua na modernização de espaços, ele constrói, com o avô, a figura desse patriarcado e a sua preferência na infância como um motivo para essa saudade. Muitas vezes, essa saudade vai aparecer na obra de Bandeira, como veremos, de forma ambivalente. Ambivalência que também é pessoal e histórica. Segundo Wilson Flores:

Bandeira vinha de uma família que possuía vínculos com o engenho de Pernambuco e que fora, por isso, diretamente afetada pelo esfacelamento do modo de vida patriarcal e pelo rebaixamento dessa experiência frente à modernização do país, o que conduziu parte dos destronados a cultivar um sentimento ambivalente de desprezo e admiração pelo progresso. Por outro lado, seu pai e seu tios (irmãos de seu pai) eram todos profissionais liberais. $\mathrm{O}$ pai, engenheiro, trabalho ativamente em estradas de ferro (foi engenheiro da Sorocabana) e na modernização de portos pelo país. (FLORES, 2015, p. 320 ).

Além disso, Sylvia Tamie Anan (2006) aponta que, no início dos anos trinta, houve o debate sobre o planejamento urbano de Recife, em torno da arquitetura residencial adequada às cidades brasileiras, a cidade se pretendia moderna, inspirada em Paris, sem a preocupação com a preservação dos edifícios históricos. Nesse contexto, um grupo defendia o mocambo, com argumentos etnológicos e ecológicos, tendo como seu principal representante Gilberto Freyre. E outro grupo acreditava que essa construção era um problema pelas condições de higiene e problemáticas sociais. 
A defesa do mocambo, grupo do qual Manuel Bandeira fazia parte, era também um resgate das raízes e a sua persistência remete à ideologia das casas grandes e à preservação desse passado por uma elite que reconhecia nele seu período áureo. Ainda, para Anan:

A discussão de uma origem mítica, ainda que localizada historicamente, era parte natural de uma tentativa de forjar uma identidade nacional e, principalmente, regional, semelhante à engendrada pelos paulistas através do modernismo. Da mesma forma que estes, e em outra escala os mineiros, os recifenses tinham tomado contato com a valorização da cultura primitiva através da vanguarda francesa, que o ajudaria a ressaltar as particularidades regionais, fossem elas da arquitetura dos mocambos, a culinária das casas-grande, os romances do ciclo da cana-de-açúcar de José Lins do Rêgo, a literatura de Manuel Bandeira (...), e finalmente os estudos sociólogos de Gilberto Freyre, além dos inúmeros nomes da engenharia civil, que, se não conseguiram criar soluções concretas para as questões da habitação popular e da cidade higiênica, souberam construir todo um imaginário em torno do Recife. (ANAN, 2006, p. 70).

Dessa forma, a obra de Bandeira também é partícipe dessa discussão e da criação de um imaginário em torno do Recife, que considera uma oposição ao progresso. Algo que fica claro nas crônicas, nos comentários da preservação arquitetônica e nos poemas que tratam principalmente da infância e do saudosismo de um passado.

Como foi abordado no capítulo 1 deste trabalho, a partir de 1920, com o crescimento industrial, o meio urbano avançava cada vez mais, chocando-se com o tradicionalismo rural até então predominante na sociedade e reproduzindo prerrogativas e desigualdades. Dessa forma, a cidade em processo de modernização é um espaço que coloca em tensão esses aspectos, tensão que reaparece no texto literário. Portanto, busca-se doravante propor a mediação da cidade como composto brasileiro e cordial da obra bandeiriana.

\subsubsection{A evocação de um passado de uma cidade particular}

"Evocação do Recife" é um poema feito a pedido de Gilberto Freyre para o Livro do Nordeste, obra comemorativa de cem anos do Diário de Pernambuco, publicada em 1925, em que se faz explícita a visão de rejeição da modernização e um saudosismo na busca da construção regional do Nordeste. Tal representação da cidade está presente no poema de forma bem singular e tensionada em articulação com a memória íntima e subjetiva. Vejamos:

\section{Evocação do Recife}

Recife 
Não a Veneza americana

Não a Mauritsstad dos armadores das Índias Ocidentais

Não o Recife dos Mascates

Nem mesmo o Recife que aprendi a amar depois -

Recife das revoluções libertárias

Mas o Recife sem história nem literatura

Recife sem mais nada

Recife da minha infância

A Rua da União onde eu brincava de chicote-queimado e partia as vidraças da casa de dona [Aninha Viegas

Totônio Rodrigues era muito velho e botava o pincenê na ponta do nariz

Depois do jantar as famílias tomavam a calçada com cadeiras, mexericos, namoros, risadas A gente brincava no meio da rua

Os meninos gritavam:

Coelho sai!

Não sai!

À distância as vozes macias das meninas politonavam:

Roseira dá-me uma rosa

Craveiro dá-me um botão

(Dessas rosas muita rosa

Terá morrido um botão...)

De repente

Nos longe da noite

Uma pessoa grande dizia:

Fogo em Santo Antônio!

Outra contrariava: São José!

Totônio Rodrigues achava sempre que era São José.

Os homens punham o chapéu saíam fumando

E eu tinha raiva de ser menino porque não podia ver o fogo

Rua da União...

Com eram lindos os nomes das ruas da minha infância

Rua do Sol

(Tenho medo que hoje se chame do Dr. Fulado de Tal)

Atrás de casa ficava a Rua da Saudade...

.... onde se ia fumar escondido

Do lado de lá era o cais da Rua da Aurora...

... onde se ia pescar escondido

Capiberibe

- Capibaribe

Lá longe o sertãozinho de Caxangá

Banheiros de palha

Um dia eu vi uma moça nuinha no banho 
Fiquei parado o coração batendo

Ela se riu

Foi meu primeiro alumbramento

Cheia! As cheias! Barro boi morto àrvores destroços redomoinho sumiu

E nos pegões da ponte do trem de ferro os caboclos destemidos em jangadas de [bananeiras

Novenas

Cavalhadas

Eu me deitei no colo da menina e ela começou a passar a mão nos meus cabelos

Capiberibe

- Capibaribe

Rua da União onde todas as tardes passava a preta das bananas com o xale vistoso de [pano da Costa

E o vendedor de roletes de cana

$\mathrm{O}$ de amendoim

Que se chamava midubim e não era torrado era cozido

Me lembro de todos os pregões:

Ovos frescos

Dez ovos por uma pataca

Foi há muito tempo...

A vida não me chegava pelos jornais nem pelos livros

Vinha da boca do povo na língua errada do povo

Língua certa do povo

Porque ele é que fala gostoso o português do Brasil

Ao passo que nós

O que fazemos

É macaquear

A sintaxe lusíada

A vida como uma porção de coisas que eu não entendia bem

Terras que não sabia onde ficavam

Recife...

Rua da União...

A casa de meu avô...

Nunca pensei que ela acabasse!

Tudo lá parecia impregnado de eternidade

Recife...

Meu avô morto.

Recife morto. Recife bom, Recife brasileiro como a casa do meu avô.

Rio, 1925

(BANDEIRA, 2009, p. 133-136). 
"Evocação do Recife" é um poema longo, com versos livres, que apresenta vários acontecimentos e situações aparentemente simples, cotidianas, como as brincadeiras de crianças, costumes ou um cotidiano daquela região, o que o eu-lírico revela ao leitor como situações íntimas e subjetivas, tal como a emoção ao ver uma moça "nuinha" no banho. Em todo o poema, há um tom de recordação que revela uma melancolia frente às mudanças e "uma necessidade subjetiva de reconquistar tempo e espaço passados" (ROSENBAUM, 1993, p. 41). Mas a melancolia é apresentada em conjunto com um tom ameno dessas recordações tão infantis e líricas.

O poema, sendo uma evocação, é construído com verbos no passado (brincava, era, tomavam, gritavam etc), o que marca essa recordação. Mas, no momento da leitura, as cenas e lugares evocados são reorganizados no espaço literário e se presentificam.

A lembrança se faz viva nesse espaço ao ser narrada e pode mostrar uma percepção de mundo. Há a construção de um mundo mágico, como destaca Arrigucci. As ruas de belos nomes (Rua da União, Rua do Sol, Rua da Saudade), acompanhadas do comentário ao leitor entre parêntese ("Tenho medo que hoje se chame Dr. Fulano de Tal"), entre outros fatores, contribuem para a construção desse mundo, que pode trazer emoções e questões nem sempre conscientes, mas que estão ali presentes.

Nessas recordações, há uma melancolia pela cidade não ser mais como é evocada. As reticências, que seguem o nome de lugares da infância, como "Rua na União...", "Recife...", “A casa do meu avô...", "foi há muito tempo...", também marcam a recordação e ajudam a conferir um tom melancólico, dando a sensação de um pensamento em torno dessas palavras por parte desse eu-lírico. Versos que seguem essas estruturas reforçam a saudade melancólica que expressa a voz do eu lírico:

Rua da União...

Com eram lindos os nomes das ruas da minha infância

Assim, com a construção de recordações da infância de um sujeito, Recife vai sendo apresentada para o leitor. Na primeira estrofe, o primeiro verso é composto com o nome da cidade que se evoca, isolado, o que vai acontecer em outros momentos do poema. Nos versos seguintes, há repetidos advérbios de negação, em que Recife é dividida em várias com o artigo "o" ou "a" determinando cada uma:

Recife

Não a Veneza americana 
Não a Mauritsstad dos armadores das Índias Ocidentais

Não o Recife dos Mascates

Nem mesmo o Recife que aprendi a amar depois -

Recife das revoluções libertárias

Mas o Recife sem história nem literatura

Recife sem mais nada

Recife da minha infância

As negações, seguidas da conjunção adversativa "mas", deixam claro qual é o Recife que se quer recordar, o Recife da infância. É anunciado ao leitor um poema que vai, portanto, tratar de uma memória íntima, e não das histórias oficiais e nem o que aparece na literatura, mas o Recife da infância do sujeito, lírico. É significativa a forma que o poeta responde ao pedido de Freyre para a construção de um poema sobre a cidade: com, ao menos aparentemente, íntimas recordações da infância que aproxima cordialmente o leitor pelo particular em um país que tem como marca a confusão entre o público e o privado.

Como foi trabalhado, o "homem cordial", formado na importância da família (patriarcal), estranha a impessoalidade, suas relações apresentam bases pessoais e, dessa forma, o público e privado ficam comprometidos. Além disso, nessa dificuldade à impessoalidade, há a dificuldade em relação a abstrações, como foi explanado no capítulo 1. Na construção de um poema que fala de uma cidade de forma tão íntima, e negando o que pode ser mais abstrato (o Recife das revoluções, das histórias e da literatura), o afetivo e o próximo do eu-lírico se abre ao leitor. $\mathrm{O}$ trabalho poético parece querer envolver um leitor que quer tudo com bases pessoais, o captando de forma íntima, aparentemente simples e sutil.

Tudo é substituído por algo muito familiar e, assim, mais concreto, como uma criança faz, com o apoio da família. Pode-se dizer que a sociedade cordial também busca tornar tudo mais familiar com o apoio da família e é marcada pela persistência da centralidade da família patriarcal nessa sociedade.

Além disso, as negações feitas na primeira estrofe, seguidas da afirmação em falar do Recife da infância, envolvem-se em uma concepção poética de atenção ao cotidiano, que Bandeira defende, já que a poesia viva e cotidiana não se encontrará nas histórias oficiais, mas se encontrou no poema em cenas de um cotidiano observado por um menino em uma cidade ainda não moderna.

Com a nostalgia dessa cidade do passado, a voz do texto se localiza socialmente. Apesar de o poema ser de 1925, época de crescente, mesmo que ainda incipiente, modernização das áreas urbanas brasileiras, e escrito no Rio de Janeiro, capital em que essa modernização é ainda 
mais acelerada, fala-se de uma região do Nordeste, local em que a modernização não chega com a mesma velocidade, e ressaltam-se aspectos provincianos, típicos de interior:

Depois do jantar as famílias tomavam a calçada com cadeiras, mexericos, namoros, risadas A gente brincava no meio da rua

Aspectos da tradição regionais também são ressaltados, como comprovam os seguintes versos:

Novenas

Cavalhadas

A voz que revela esses aspectos é, ainda, relacionada a um menino, o que é frequente na obra de Bandeira. Há uma mescla entre o menino (que observa e vivencia o que está no poema: as emoções e acontecimentos da infância, as ruas da infância, o Recife da infância) e o poeta adulto (que observa no momento presente da construção do poema esse Recife da infância). Tem-se a perspectiva da vivência do menino com as palavras de adulto. O que versos, que trazem palavras do universo de uma criança, comprova, tais como: "Uma pessoa grande dizia”, "A gente brincava no meio da rua”.

As palavras são de adulto, mas é uma linguagem simples, em que a humildade e a simplicidade características da obra madura de Bandeira se fazem presentes. Há também a inserção de cantigas e brincadeiras infantis, o que aproxima do popular. Não é só a narração dessas brincadeiras, mas, no poema e por meio da leitura, tem-se vivo o que os meninos gritavam:

Os meninos gritavam:

Coelho sai!

Não sai!

Em um outro poema bastante conhecido de Bandeira, "Profundamente", também notase o uso de situações passadas na infância em Pernambuco, assim como o contato com o passado regional brasileiro, como mediação para falar da morte. De novo, a voz lírica se relaciona com o infantil e se apresenta até a idade desse menino: "Quando eu tinha seis anos". O passado narrado no poema é atualizado no presente, nas palavras de Arrigucci (1990), “como lembrança viva" experimentada no poema por esse eu-lírico menino e adulto. 
Esse sujeito lírico que também tem algo de infantil não comporia a caracterização de poeta menor discutido no capítulo 1 deste trabalho? O que envolve não só algo do próprio poeta, mas um poeta parte de uma realidade história local. Uma poesia construída a partir de simples emoções da infância, e não grandes abstrações, em uma caracterização infantil em um lugar provinciano que revela a importância do núcleo familiar como organizador da memória, inclusive a histórica.

Esse eu-lírico só consegue cantar a cidade apoiado na família ou em aspectos próximos. Como foi citado, em uma sociedade baseada na família patriarcal, a dependência da família é tal como a de uma criança. O brasileiro, a partir dessa noção de cordialidade, também é infantil, é preso às noções estruturantes da família tradicional. A casa do avô em "Evocação do Recife" é símbolo dessa família patriarcal e, em relação a esse símbolo, é criada uma gradação para o familiar e um movimento entre o geral e o particular:

Recife

Meu avô morto.

Recife morto. Recife bom, Recife brasileiro como a casa do meu avô.

Esses versos, marcados pelo adjetivo "morto", apresentam, novamente, o tom melancólico, trazem o avô morto, mas, mais do que isso, Recife e o Brasil reduzidos à casa do vô recuperam uma atmosfera patriarcal que o eu-poético faz parte e não quer que acabe, o avô, como homem mais velho, é o chefe daquela família, mas isso se estende à cidade, na comparação e redução do "Recife brasileiro" como a casa do avô. A melancolia se faz presente nos versos que marcam a dissolução de algo que parecia eterno, anunciando algo que ficou para trás, mas que o poema constrói novamente e faz eterno:

Nunca pensei que ela acabasse!

Tudo lá parecia impregnado de eternidade

Além disso, nesse poema, faz-se significativo o uso da mitologia pessoal do poeta (Aninha Viegas, Totônio Rodrigues, o avô). Como já vimos, essa mitologia legitima e aproxima, pela intimidade posta e a familiaridade, a matéria literária e o leitor. É uma mitologia não só de pessoas, mas que também se faz presente na imagem de Recife, sua cidade natal, a Rua da União, a casa do avô, lugares quase personificados, dos quais o eu-poético em tom recordativo parece lembrar com esse afeto melancólico relacionado à infância: 
como eram lindos os nomes das ruas da minha infância.

A rua, um espaço público, torna-se particular com o pronome possessivo "minha". A rua limitada ao íntimo do poeta também é percebida em Carlos Drummond de Andrade, por Jerônimo Teixeira (2005) em Drummond Cordial, nos seguintes versos do poema "Canção amiga":

Caminho por uma rua que passa em muitos países. Se não me vêem, eu vejo E saúdo velhos amigos.

Para Teixeira, "nessa rua que passa em muitos países, o poeta encontra apenas velhos amigos. A rua torna-se um espaço público cordial, em que encontramos apenas quem esperamos e desejamos encontrar. É uma rua particular" (TEIXEIRA, 2005, p. 60). Em Bandeira, o ambiente que o cerca e que, melancolicamente, o eu-poético faz constantemente presente é o cordial, as ruas são da sua infância e os personagens são da sua mitologia.

Mais do que velhos amigos, são pessoas e lugares não só conhecidos do sujeito lírico, mas dos leitores de uma obra que lhes fornece "um acervo tão amplo de informes pessoais desataviados, que entretanto não parecem bisbilhotices, mas fatos poeticamente expressivos. " (GILDA; CANDIDO In: BANDEIRA, 1996, p. 11).

Tudo é atravessado pelo íntimo, tornado particular em um material, a princípio, abstrato como a poesia lírica. Walter Benjamin comenta que "Baudelaire teve em mira leitores que se vêem em dificuldades ante a leitura da poesia lírica. O poema introdutório de As flores do Mal se dirige a esses leitores" (BENJAMIN, 1989, p. 103). Bandeira, como grande poeta moderno, também trabalha essa dificuldade, considerando o contex to brasileiro. Há o desejo de construir algo íntimo para produzir determinados efeitos poéticos.

Toda a simplicidade do poema, que, com o íntimo e familiar construídos como fatos poeticamente expressivos, atrai o leitor, é acrescida de complexidades articuladas à ritualização do passado colonial. No verso que começa a configurar de forma simples esse Recife da infância, "a Rua da União onde eu brincava de chicote-queimado e partia as vidraças da casa de dona Aninha Viegas", é significativa a brincadeira selecionada, que recupera o bater do chicote nas costas do negro punido e reforça relações sociais de dominação que se fazem presente no Recife do poema. $\mathrm{O}$ que se relaciona com a condição periférica de um país cuja modernização se faz por meio da utilização do passado. 
Wilson José Flores Jr. (2015), no artigo "Vou-me embora pra Pasárgada": Devaneio e Processo Social", mostra que "Vou-me embora pra Pasárgada" é um poema com um cenário luminoso e com um vínculo infantil. Mas, nesse cenário, encontra-se uma violência de fundo, extremamente ligada ao nosso passado colonial, com um saudosismo de uma mentalidade escravista, vista, por exemplo, com um mandonismo e uma objetificação de personagens femininos.

O Recife criado por Bandeira também mostra uma ingenuidade aparente, explícito nessa brincadeira com chicote citada, que nos remete a uma violência estritamente ligada à escravidão:

Até hoje, entre inúmeros jogos espalhados pelo Sudeste e Nordeste, regiões que se destacaram pelo cultivo da cana e uso de negros escravos, a cultura infantil preserva a brincadeira com as denominações: chicotinho, chicotinho queimado (...). Freyre considera ainda, jogo como: pião, papagaio, e o belisco, típicos da violência do período do engenho de açúcar. (KISHIMOTO, p. 39, 2004)

$\mathrm{Na}$ Rua da União, aparecem personagens que, mais uma vez, remetem a uma recuperação da época colonial e da escravidão: a "preta das bananas", o vendedor de cana-deaçúcar, principal produto em certa fase da colonização do Brasil. Tudo envolto em um saudosismo que a cadência lânguida do verso "foi há muito tempo...", terminado pelas reticências, confirma.

Tudo isso se encontra na poesia de Bandeira embalado em melancolia. Por exemplo, na aparente simples cantiga infantil tradicional que as meninas cantavam, é acrescido uma espécie de comentário ao leitor entre parênteses (assim como quando fala das ruas da infância):

À distância as vozes macias das meninas politonavam:

Roseira dá-me uma rosa

Craveiro dá-me um botão

(Dessas rosas muita rosa

Terá morrido um botão...)

O comentário novamente evidencia um sentimento melancólico, por meio da expressão “terá morrido". É algo que acontece em um tempo diferente dos acontecimentos narrados no poema. Os comentários não parecem ser do tempo vivenciado pelo menino sujeito da experiência lírica. Há, assim, uma relação do passado com o presente, uma organização de 
tempos em que o eu-lírico se encontra, além de uma relação melancólica com o tempo. Além disso, o passado narrado também se encontra presentificado no espaço do poema na reorganização do trabalho poético, e há uma atualização do ausente pela força da memória, algo comentado no capítulo 1 deste trabalho.

Ademais, "Evocação do Recife" é um poema inserido no contexto do Modernismo. Fazse presente, com essa cidade provinciana, o empenho modernista de conhecer o Brasil não oficial. E também destaca os aspectos linguisticamente brasileiros da variante do português, aspecto chave da programática modernista claramente evidenciada nos versos abaixo:

A vida não me chegava pelos jornais nem pelos livros

Vinha da boca do povo na língua errada do povo

Língua certa do povo

Porque ele é que fala gostoso o português do Brasil

Ao passo que nós

$\mathrm{O}$ que fazemos

É macaquear

A sintaxe lusíada

Com o Modernismo, buscou-se evidenciar o que era popular na literatura. O povo ganha espaço, assim como a língua popular, diferente da oficial que se aproxima muito mais da variante portuguesa. Discussão que se encontra no poema com as antíteses "língua errada do povo", que se transforma em "língua certa do povo" no verso seguinte.

Mesmo assim, nos versos bandeirianos, há uma separação entre o povo e o eu lírico, que não se considera parte do povo, o que é visto com o uso do pronome "ele" ao se referir ao povo e, em seguida, o "nós" que macaqueia a sintaxe lusíada. O que pode discutir o papel do intelectual, que observava e dava espaço ao popular e ao povo, mas não se misturava nessa camada da população.

Mas essa diferenciação também traz a experiência de menino, já que, seguido a esses versos, encontra-se outra vez o infantil:

A vida como uma porção de coisas que eu não entendia bem

Terras que não sabia onde ficavam

O ser infantil aproxima o poeta do povo, sendo parte de um tempo em que a vida "vinha da boca do povo". Esse menino, participante da lógica da casa do avô, entendia a vida não por terras e coisas que julgava tão abstrato, e sim pelo o que via no cotidiano do povo, mas também não se insere totalmente nisso. Não é só uma aproximação, mas também não é só um distanciamento. É o mesmo menino que, em Itinerário de Pasárgada, revela uma relação com 
o realismo da gente do povo, sem, contudo, inserir-se totalmente e que contrabalançava a fala popular e a aprendida no ginásio:

$\mathrm{Na}$ casa de laranjeiras, onde moramos os seis anos que cursei o Externato do Ginásio Nacional, hoje Pedro II, nunca faltava pão, mas a luta era dura. E eu desde logo tomei parte nela, como intermediário entre minha mãe e os fornecedores - vendeiro, açougueiro, quitandeiro, padeiro. Nunca brinquei com os moleques da rua, mas impregnei-me a fundo do realismo da gente do povo. Jamais me esquecerei das palavras com que certo caixeiro de venda português deu notícias de um companheiro que não era visto havia algum tempo: 'O seu Alberto está com os pulmões podres'. Essa influência da fala popular contrabalançava a da minha formação no Ginásio. (BANDEIRA, 2012, p. 31).

Ainda, em "Vou-me embora para Pasárgada", poema em que o sujeito recupera brincadeiras infantis e a voz lírica se aproxima, por vezes, a de um menino, como em "andarei de bicicleta/montarei em burro brabo...”, há um menino brincando sozinho com personagens femininas ao seu serviço ("mando chamar a mãe d'água"). De acordo com a análise de Wilson Flores (2015), Pasárgada é

um mundo de brincadeira em que o poeta brinca sozinho, enquanto fantasia o outro que existia apenas para satisfazê-lo (...). Temos um sujeito solitário, um tanto enclausurado, que se embala no acalanto de brincadeiras infantis ao mesmo tempo que fantasia um estado de liberdade cujo modelo é do senhor solidamente garantido em suas prorrogativas e para quem o mundo é uma projeção de si. (FLORES, 2015, p. 320).

No poema aqui estudado, o poeta se abre para o outro, em articulação com a projetiva modernista, com a língua do povo e com outras terras, o que é feito não sem limitação. Tal limitação é marcada pela não proximidade do poeta ao povo ou pelo não entendimento dessas terras. Na estrofe seguinte, o eu-lírico afasta-se disso para voltar ao íntimo e ao projetado para si, os países que não sabia onde ficavam são substituídos por Recife e, em seguida, pela casa do vô, que é síntese de uma família rural autossuficiente e com leis próprias:

Recife...

Rua da União...

A casa de meu avô...

Dessa forma, em "Evocação do Recife", há a articulação de uma matéria que se constrói como pessoal em situações da infância, da realidade brasileira e do programa modernista, mas 
tal articulação é tensionada. Por isso ela permite exibir-se uma voz socialmente localizada e uma preferência a um tempo que passou.

Percebe-se que essa preferência é mais do que a construção da ideia de que Bandeira preferia os anos vividos na infância em detrimento da vida adulta devido à sua doença. Em Bandeira, a partir da saudade melancólica do passado, há a um sentimento de perda do lugar em que o sujeito confortavelmente se reconhecia, o que não se relaciona propriamente com uma época de Recife, que Bandeira pouco viveu, mas se faz presente a discussão de um progresso que vem com o sentimento de perda desse lugar simbólico do passado para alguns.

Há a celebração de um passado e a problematização do progresso ("tenho medo que hoje se chame Dr. Fulano de Tal") com formas, mesmo falando de uma cidade, que sugerem o provinciano, o rural e o tradicional ("Novenas/ Cavalhadas"). Questões como a memória, essa celebração e essa problematização são típicas do momento intelectual do final dos anos 20 e de 30, em que surgia uma forte preocupação com a realidade brasileira, encontrada nos estudos de interpretação histórica e na arte.

A maneira como esses fatores aparecem na obra de Bandeira, em especial nesse período, encontram-se com ideias contra a nova ordem capitalista e a decadência da família de intelectuais que podem apresentar um apego a um mundo de relações patriarcais da infância que, no caso de Bandeira, centra-se na casa do vô.

"Evocação do Recife" é carregado de afeto e de celebração das memórias da infância. Por exemplo, os versos que trazem o rio Capibaribe funcionam como um refrão, o seu ritmo configura uma atmosfera aparentemente amena que conflui tão bem com essas memórias. No Itinerário, o próprio Bandeira explica a construção desse aspecto musical em torno do nome do rio, mas não sem antes o envolver em uma história pessoal:

Certo dia (José Veríssimo) perguntou à classe: "Qual é o maior rio de Pernambuco?". Não quis eu que ninguém se me antecipasse na resposta e gritei imediatamente do funda da sala: "Capibaribe!". Capibaribe com a, como sempre tinha ouvido dizer no Recife. Fiquei perplexo quando Veríssimo comentou, para grande divertimento da turma: 'Bem se vê que o senhor é um pernambucano!' e corrigiu: "Capiberibe". Meti a viola no saco, mas na "Evocação" me desforrei do professor (...). Todavia, outra intenção pus na repetição. Intenção musical: Capiberibe a primeira vez com e, a segunda com a, me dava a impressão de um acidente, como se a palavra fosse uma frase melódica dita da segunda vez com bemol na terceira nota. (BANDEIRA, 2012, p. 65).

O rio, assim como outros traços comentados do poema, também tem algo de melancólico em um verso construído como pedaços de lembranças e com uma certa confusão: 
Cheia! Cheia! Barro boi morto árvores destroços redemoinho sumiu.

$\mathrm{O}$ verso fala de um boi morto que passa em uma cheia no Capiberibe. Esse fato é também conhecido da poética de Bandeira, como no poema "Boi morto", comentado no capítulo 1 deste trabalho, e evoca uma atmosfera de destruição, confirmada pelo verso arrastado nessa confusão de palavras em destroços.

Assim, há, em todo o poema, a construção de um afeto e de uma melancolia, o que é próprio da realidade brasileira, já que não é apenas a negação de uma nova ordem, mas há a tensão da realidade contraditória de um país em que, melancolicamente, raízes coloniais se fazem sempre tão profundas.

Considerando o exposto, no poema, o nacionalismo existente é apresentado a partir do íntimo do eu lírico, sendo presente uma voz que atua principalmente pela emoção e por sentimento do coração, e que se mostra tão dependente da família. Tais características são do "homem cordial" e se contradizem com a modernização que leva, cada vez mais, a atitudes antifamiliares, pois valorizam virtudes individualistas e a competividade do mercado.

Há, com isso, a oposição passado e presente, com uma saudade desse passado - outra característica, o saudosismo, da cultura luso-brasileira que envolve o nosso "homem cordial". Também a cidade no poema redesenhada para recuperar um passado pela mediação da infância, algo, inicialmente, leve e harmonioso, como os belos nomes das ruas e as imagens pictóricas da infância que o poema vai construindo, mas que carrega referências coloniais e violentas.

Entretanto, mesmo parecendo apenas se apoiar em ideias estruturantes da sociedade colonial do "homem cordial", é uma lírica sobretudo ambígua e construída, assim, como uma observação atenta da sociedade brasileira da época. Insere-se na contradição da passagem modernizadora do rural para o urbano, no tradicional que continua: tudo sendo atravessado pelo particular e familiar, apresentando-se um conforto em se reencontrar com o passado recriado no espaço do poema em uma melancolia em querer conservar o que passou ou está passando.

Dessa forma, o poema responde ao processo de modernização da época não só com uma valorização ou um saudosismo do passado, mas com a recuperação dele e um pertencimento a tudo isso. A contradição desse processo também se encontra nas diversas contradições do poema: um adulto que fala emoções de um menino; o eu-poético que, ao mesmo tempo, afastase e se aproxima do povo; um tom ameno e de afeto que se revela melancólico e com referências à violência de uma história de colonização, entre outras contradições que o eu-lírico se vê como parte. 
Além disso, o poema se relaciona à cordialidade, representando aspectos cordiais: por exemplo, o Recife e as suas ruas reduzidas ao particular do eu lírico, que envolve a característica do público invadido pelo privado do "homem cordial", que faz parte daquilo que melancolicamente o eu-poético ver acabando, afinal "a cordialidade impõe que o círculo da familiaridade não seja rompido" (TEIXEIRA, 2005, p. 47), e a familiaridade é com esse passado.

Mais do que isso, é possível afirmar que a cordialidade está como forma no poema, que, na abertura de fatos íntimos e com uma linguagem simples e próxima, atrai, de forma cordial, um leitor que teria horror às distâncias e que tudo tenta aproximar do coração, captando-o, com a criação dessa empatia conhecida na poesia de Bandeira, para colocá-lo também como parte desse dilema estrutural da sociedade brasileira que passa por essas questões ao se modernizar.

Dessa forma, percebemos como "o caráter acolhedor", para citar Gilda e Candido (1996), do verso bandeiriano, relaciona-se com a cordialidade e consiste em "atrair o leitor para essa despojada comunhão lírica no cotidiano e, depois de adquirida a sua confiança, em arrastalo para o mundo das mensagens oníricas" (GILDA; CANDIDO, 1996, p. 11).

\subsubsection{O Pernambuco de 1821 e o Pernambuco de Bandeira}

Há, em Crônicas da Província do Brasil, vários textos que ajudam a iluminar essa relação do autor moderno com o saudosismo da infância analisada em "Evocação do Recife". Nas crônicas, muitas vezes, faz-se presente também a valorização de um passado histórico, no sentindo de redescoberta das cidades brasileiras empreendidas pelos modernistas. Essa valorização se encontra em textos que tratam da arquitetura de cidades brasileiras, como "Bahia", "Um purista do estilo colonial”, "Velhas igrejas", entre outras.

Outro exemplo é a crônica "O que era Pernambuco de 1821 ”, que foi publicada em $A$ Província, em 1929. O texto fala sobre o livro da inglesa Maria Graham, intitulado Journal of a Voyage to Brazil and Residence there during part of the years 1821, 1822 and 1823. Assim como em outras crônicas, o tom é de uma conversa com amigos, que aproxima o leitor para as informações que ele seleciona e comenta. No começo, antes de falar do livro de viagem sobre o qual vai traçar comentários, o autor conta sobre um amigo que gostava desse tipo de leitura:

$\mathrm{O}$ meu amigo distingue-se entre os amadores dessas coisas pelo amor quase de namorado que põe na procura e aquisição de cada volume. Não é para ele uma compra vulgar. Não. É sempre uma pequena aventura, uma deliciosa aventura em que ele emprega tanto pudor e delicadeza como na aproximação 
e cerco de uma mulher. Obtido o volume cobiçado, a sua leitura tem para ele o sabor de idílio. (BANDEIRA, 2006, p. 73).

A introdução com esse caso contado ao leitor revela esse tom de conversa, reforçado pela ênfase com o "não" e pelo uso da palavra "coisas", que confere um aspecto mais informal, por ser uma palavra que pode ser substituída por outras que dariam uma ideia de maior conhecimento de vocabulário. O caráter de conversa informal também está no trecho nas comparações da compra com um amor de namorado, com "uma deliciosa aventura", definindo para o leitor o amor do amigo pelos livros de viagens. Tom de "contar um caso" que continua em toda a crônica, contando também o que se passou com Maria Graham em Pernambuco e as suas impressões.

Além disso, há o uso do diminutivo em vários momentos ("exemplar velhinho", "negrinha", "homenzinho"), conforme já foi discutido neste trabalho, o diminutivo é um recurso linguístico comum em Bandeira e que faz parte da dimensão linguística da cordialidade, já que configura, mesmo que ironicamente, um afeto e uma marca da oralidade.

No texto, o uso desse recurso tão típico brasileiro se encontra com palavras de línguas estrangeiras, como em "homenzinho muito smart". O que faz parte da mistura do discurso da autora inglesa e do cronista brasileiro que se encontra ao longo da crônica.

Essa mistura, às vezes, não deixa claro se os comentários são da própria escritora ou do cronista, e se confirma no momento em que a voz narrativa da crônica diz repetir o que Maria Graham escreveu sobre o Recife: "Vou repetir um pouco do que ela escreveu sobre o Recife. É o único jeito de aliviar minha paixão anacrônica.” (BANDEIRA, 2006, p. 74). Mesmo assim, no parágrafo seguinte, o possessivo "minha" se repete "Atravessa a minha província natal um período memorável”. Em meio a esse discurso, há algumas citações diretas marcadas por aspas: “'É um homem severo"”, diz ela", e as palavras estrangeiras, que lembram um discurso indireto livre:

Longe de atemorizar-se, ficou ela encantada de desembarcar e observar a cidade em estado de cerco, espetáculo inteiramente novo para ela. Os seus primeiros passos fora para o palácio, onde esteve com o governador, a senhora e as filhas. Madame Luís do Rego era agradável, rather pretty, e falando inglês como inglesa (sua mãe, a viscondessa do Rio Seco, era irlandesa. "Nada mais afável e lisonjeiro que as suas maneiras e as de suas meninas", uma das quais de grande formosura. (BANDEIRA, 2006, p. 74; grifo nosso).

Esse parágrafo remete também há uma valorização do inglês que se relaciona a uma conhecida desvalorização do Brasil. As qualidades da Madame Luís do Rego estão em conjunto 
com o fato dela falar inglês como uma inglesa. Essa desvalorização coexiste com o fato da construção de imagens para inglês ver, que transmitem para Maria Graham a "alegria pitoresca" comentada no final da crônica.

Além disso, realça-se na crônica a recepção cordial aos estrangeiros: “Apesar da incerteza da hora (...), o governador e a senhora não se descuidavam de obsequiar os hóspedes da fragata inglesa, aos quais ofereceram um jantar em palácio. Jantava-se naqueles tempos às quatro e meia. A recepção foi muito cordial. " (BANDEIRA, 2006, p. 75) ou "depois do discurso, a negociação sobre a roupa foi rápida e os estrangeiros obtiveram não só como pretendiam como outros grandes favores e provas de cortesia (BANDEIRA, 2006, p. 77).

Em torno dessa recepção caracterizada pela estrangeira, Sérgio Buarque afirmou em Raizes do Brasil que:

\begin{abstract}
A lhaneza no trato, a hospitalidade, a generosidade, virtudes tão gabadas por estrangeiros que nos visitam, representam, com efeito, um traço definido do caráter brasileiro, na medida, ao menos, em que permanece ativa e fecunda a influência ancestral dos padrões de convívio humano, informados no meio rural e patriarcal. Seria engano supor que essas virtudes possam significar boas maneiras, civilidade.
\end{abstract}

(HOLANDA, 1963, p. 187).

Outra observação importante sobre a obra da inglesa está nos espaços conhecidos de poemas de Bandeira e que o próprio cronista afirma ser no livro dessa autora que encontrou algumas imagens poéticas que estariam presentes em sua meninice no Recife:

\begin{abstract}
A sua última conquista foi o livro de Maria Graham (...), exemplar velhinho ilustrado de estampas amoráveis desenhadas pela autora, em umas das quais tive o prazer de encontrar a preta das bananas da minha "Evocação do Recife", com todos os detalhes característicos que faziam o encanto da minha meninice nas tardes da rua da União; o largo tabuleiro de pau, o xale vistoso de pano de Costa (...). (BANDEIRA, 2006, p. 73).
\end{abstract}

Com esse trecho, tem-se uma contradição que o poema "Evocação do Recife" faz parte. Como o próprio título da crônica afirma, o livro de Maria Graham traz observações de Pernambuco de 1821 e nele há a ilustração da preta das bananas.

Contudo, Bandeira viveu sua infância em Recife em 1892 a 1896, quando volta com a família para Pernambuco, período em que teria se dado a convivência com os personagens da sua mitologia, como "Totônio Rodrigues", “d. Aninha Viegas”, “a rua da União”, que se encontram em "Evocação do Recife", com a preta das bananas. 
Dessa forma, a "paixão anacrônica", que o cronista afirma sentir no começo da crônica, é característica da saudade de "Evocação do Recife", que, então, causa contrariedade por destacar o passado que continua no presente.

Assim, a imagem da preta das bananas se articula a uma época de Recife marcada pela escravidão, colocando no espaço do poema uma figura que é marca de um Pernambuco de 1821, mas que permanece na infância do poeta e faz parte daquilo que ele não quer que acabe. O que, na crônica, a própria voz narrativa identifica como anacrônica.

O cronista, então, traz as observações do livro para aliviar essa paixão anacrônica. Essas observações trazem ainda contradições profundas da escravidão no contexto brasileiro, contradições que são realidade histórica do país. As cenas de escravidão impressionam muito ao olhar estrangeiro ("Impressionaram-lhe muito as cenas da escravidão, o mercado dos cativos”), observação que é seguida de relatos impensáveis nos livros brasileiros do mesmo período do livro de viagem abordado pelo cronista:

\footnotetext{
'cerca de cinquenta criaturas moças, moleques e raparigas com todas as aparências da doença e da fome, sentadas ou deitadas na rua no meio dos mais imundos animais.' Do balcão da casa do cônsul presenciou uma mulher branca, um demônio, bater numa negra, torcendo-lhes os braços cruelmente. Em Olinda, perto do Varadouro, viu ao pôr-do-sol um cão puxar da areia um braço de negro defunto e devorá-lo... (BANDEIRA, 2006, p. 75).
}

Tal observação torna patente uma realidade que convivia falsamente com as ideias burguesas tão contraditórias aqui. Logo após as reticencias que marcam o fim dessa observação na crônica, mas também que uma possível continuação, parte-se rapidamente para outro assunto “Como andavam vestidas as recifenses daquele tempo? (...) Na rua traziam um xale ou manta das cores mais alegres, cadeias de ouro no pescoço e nos braços, brincos de ouro" (BANDEIRA, 2006, p. 76), o que contrasta com o mercado dos cativos descrito no parágrafo anterior.

Dessa forma, as belezas de Olinda, a recepção cordial, as qualidades da Madame Luís do Rego são contrastadas também com as cenas de escravo: "salvo as cenas de escravos, tudo foi alegria pitoresca para os seus olhos". (BANDEIRA, 2006, p. 77). A paixão anacrônica por essa cidade poder revelar que a saudade característica da obra de Bandeira não é uma simples saudade da infância ou uma defesa das construções do patrimônio que se faz em várias crônicas sobre cidades.

A saudade é relacionada até mesmo ao que não viveu, como foi discutido no capítulo 1 desta pesquisa. Em uma das crônicas que Bandeira discute a preservação arquitetônica, "Velhas igrejas", Sylvia Tamie Anan comenta sobre o trecho "Para Olinda, cujo oiteiro nunca subi 
menino" que, em seguida, revela uma decepção por subir no oiteiro e descobrir a igreja restaurada, não descobrindo seu aspecto original. Dessa forma, a estudiosa conclui que:

Na visão da preservação arquitetônica presente nas crônicas de Bandeira, em que pese sua grande cultura e conhecimento de causa, a memória da infância influi até mesmo na avaliação de monumentos que ele não conheceu em criança, revelando uma estranha necessidade de conhecer a igreja como poderia tê-la visto quando menino. Tal necessidade permanece a respeito de cidades que o cronista conheceu apenas na juventude, e que, se de um lado oferecem vislumbres do arquiteto que Bandeira teria sido, de outro esclarecem uma visão do passado que não era exclusivamente sua, mas que expressava, como é possível constatar, as ansiedades de todo um grupo. (ANAN, 2006, p. $71)$.

Wilson Flores (2015) também discute algumas contradições da saudade bandeiriana em "“Vou-me embora pra Pasárgada': devaneio e processo social”:

Bandeira flertava, ocasionalmente, com certas motivações passadistas (para usar um termo recorrente entre os modernistas e que Bandeira também empregava bastante), um tanto indeciso em tratar o mundo dos engenhos como algo que pouco lhe dizia respeito porque, de fato, não o conheceu (como afirma diretamente na crônica "Impressões de uma cristãonovo do regionalismo", publicada originalmente em A Província, em 9 de dezembro de 1928, e depois reunida em Crônicas da Província do Brasil) e certo saudosismo desfocado e contraditório que, ocasionalmente, o fazia fantasiar "uma burra saudade de engenhos, onde aspirou aquele cheiro das tachas de açúcar, das quais disse Nabuco, e com razão, que nos embriaga a vida toda." (FLORES, 2015, p. 323).

Assim, a saudade de Bandeira é histórica e contraditória, é a saudade de uma preta das bananas da sua "Evocação" que, na crônica, faz parte de um mundo que não conheceu, mas que, ao mesmo tempo, é parte de um mundo da sua infância no poema. Essa contradição presente e passado que revela a saudade de um tempo está também em várias outras crônicas, pois, apesar de ser um gênero voltado para o presente, é comum que as crônicas bandeirianas se centrem no passado. Como em "O que era o Pernambuco de 1821", que, com o pretexto da discussão de um livro, envolve-se na província natal do cronista em um período passado que julga memorável, mas que o próprio tex to revela anacrônico e evidencia contradições, que estão na forma do texto, mas que refletem as próprias cidades brasileiras da época, tais como o contraste das cenas dos escravos com o restante da população.

É com essa saudade histórica e contraditória que esta crônica responde ao processo modernizador da época em que foi escrito, explicitada no texto por meio da "paixão anacrônica". O adjetivo "anacrônica" contrasta com o moderno, mas revela o processo de 
modernização brasileiro, que atualiza o arcaico e um passado colonial que se fazia presente. Adjetivo que também se relaciona a uma época em que o narrador não viveu, mas que, ainda assim, faz-se presente e até se tem paixão. O contraste brusco das observações do mercado de escravos com belezas do lugar ou com a descrição de como andavam as recifenses também mostra um contraste que era da sociedade e que permanece como aspecto formal da crônica.

Nesse confronto passado e presente, encontra-se também a cordialidade, já que é ela própria uma herança de um passado brasileiro que permanece como parte desse processo de modernização contraditório. E está na crônica no uso do diminutivo, algo parte da dimensão linguística da cordialidade para familiarizar e aproximar, aparecendo ironicamente ao lado de palavras estrangeiras, assim como na ênfase do particular, marcado pelo possessivo "minha" em "minha província”, já que a esfera pública é comprometida para o brasileiro cordial. Além disso, tem-se discutida a representação da recepção cordial aos estrangeiros, considerando uma característica positiva pela qual se conhece os brasileiros e que é própria do "homem cordial".

\subsubsection{O progresso contraditório e quem está à margem}

Como vimos, Manuel Bandeira, de acordo com Jerônimo Teixeira, insiste em fixar formas que, mesmo nas cidades, possuem atmosfera provinciana, não como aspecto ultrapassado, mas como aspecto presente e atuante na modernidade. Como se percebe no poema "Camêlos", com os valores tradicionais, a nostalgia da infância, o diminutivo dos brinquedos, entre outros aspectos comentados no capítulo 1 deste trabalho, "no tumulto das ruas" da cidade. Esse teor irônico face à modernidade está também na nostalgia e no afeto a situações da infância do poema "Evocação do Recife" e na paixão anacrônica na crônica "O que era o Pernambuco de $1821 "$.

No poema de Libertinagem que segue "Evocação do Recife", "Poema tirado de uma notícia de jornal", esse teor irônico se dá de forma bem diferente, a matéria literária é a cidade do Rio de Janeiro, cidade em que a crescente urbanização se fazia presente e, com ela, um progresso contraditório:

\section{Poema tirado de uma notícia de jornal}

João Gostoso era carregador de feira livre e morava no morro da Babilônia num barracão sem número Uma noite ele chegou no bar Vinte de Novembro

Bebeu

Cantou

Dançou

Depois se atirou na lagoa Rodrigo de Freitas e morreu afogado. 
(BANDEIRA, 2009, p. 136)

O poema de versos livres representa a estética modernista e tem como literária uma matéria prosaica, além de mudanças em relação à estética tradicional. É um poema breve, assim como a vida retrata ali, mas representa uma série de questões.

Apesar de ter poucos versos, o título é longo, o que já demonstra um primeiro contraste. Nesse título, deparamos-nos com outro contraste, pois fica claro que o poema deriva de uma notícia. Tal fato se esclarece não apenas no título, mas, por meio da linguagem objetiva e concisa, que leva para o poema traços de linguagem jornalística, uma forma de comunicação imediata, em que o objetivo é a informação. Esse tipo de comunicação espanta no literário, já que se afasta do que é esperado para um texto literário, que busca não passar uma informação objetiva, mas afetar a experiência do leitor. A linguagem do jornal

consiste em isolar os acontecimentos do âmbito onde pudessem afetar a experiência do leitor (...). Na substituição da antiga forma narrativa pela informação e da informação pela sensação reflete-se a crescente antrofia da experiência. (BENJAMIN, 1989, p. 107)

Tem-se presente a concepção que Bandeira busca defender, de que a poesia pode ser retirada de tudo, até do mais prosaico e cotidiano. Essa concepção aproxima o leitor, afastandose das grandes abstrações a que a arte poética é associada. Em relação a essa arte das grandes abstrações, o jornal estabelece um profundo contraponto, sendo uma forma de comunicação, a princípio, contrária à literatura.

O poema parte dessa forma de comunicação, mas, dialeticamente, por meio do trabalho poético, afasta-se dela e se aproxima de uma narração que "não tem a pretensão de transmitir um acontecimento, pura e simplesmente (como a informação o faz); integra-o à vida do narrador, para passá-lo aos ouvintes como experiência” (BENJAMIN, 1989, p. 107).

Utilizando os recursos da notícia, e do estranhamento desses recursos na linguagem do poema, o poeta chama a atenção do leitor para a vida que está sendo narrada, com a criação de uma empatia humana, que se desenvolve tão bem com a expressão emotiva do brasileiro cordial.

Para Arrriguci (1990), raras vezes Bandeira conseguiu tirar tanto de tão pouco, o que explica bem a sua característica de esconder o complexo em algo aparentemente simples, a notícia, algo para ser lido e esquecido e que nos remete às experiências em cidades modernas, torna-se um poema desentranhado, que 
renova sempre o convite à nossa compreensão. (...) De algum modo, o poema busca assim a adesão do leitor, ferindo sua sensibilidade e imaginação, tentando agravar-se em sua memória. Na verdade, busca incorporar-se na própria experiência do leitor, pedindo uma resposta compreensiva, como algo que agora lhe pertence. (ARRIGUCI, 1990, p. 90).

Transformando-a em poema, a notícia tem seu sentido alterado, ao mesmo tempo que mantém o sentido original. Diferente da notícia, que é só o relato de algo de que se toma conhecimento diariamente e esquece, o poema questiona o leitor sobre o destino colocado ali. $\mathrm{O}$ que acontece já a partir do choque produzido pelo título, que anuncia uma matéria antes jornalística como literária. Além disso, a simplicidade, não só das palavras ou da construção do poema, mas também do personagem e da notícia, que é cotidiana, trabalhada como poema, faz o leitor preencher vazios de sentido.

Assim, algo tão impessoal como a notícia da morte de um desconhecido, mas que também se faz um tipo conhecido por todos pelas cidades modernas, é aproximado do íntimo do leitor e, de certo modo, incomoda.

O poema é todo ele a narração dessa notícia, de forma impessoal, marcada pelo narrador ausente, como se fosse uma notícia de jornal, uma objetividade, como foi comentado, a princípio, tão contrária ao subjetivismo típico da lírica.

Apesar da forma objetiva, que o aproxima da comunicação jornalística, o poema tem um ritmo marcado, produzido, por exemplo, pela falta de pontuação. Além disso, o formato dos versos, em especial os verbos que se encontram cada um em um verso e rimam entre si, distanciam o poema desse tipo de comunicação da notícia.

Nos dois primeiros versos, há a descrição de um personagem marcada por indefinições. Já no título, há a presença do artigo indefinido "uma" acompanhando "notícia de jornal", ou seja, a notícia de jornal não é uma notícia específica e particular, é caracterizada de forma vaga, imprecisa e generalizada, ou até mesmo corrente e cotidiana.

Na caracterização do personagem, essa generalização continua, João é um nome comum no Brasil, o sobrenome, algo que retiraria essa generalização, é substituindo pelo apelido "Gostoso", assim, algo rebaixado e erótico dá o seu reconhecimento social. Tal apelido também remete, pelo erotismo da palavra, à disciplina de simpatia muito relacionada aos brasileiros, mas que, com o nome João, não deixa de indicar imprecisão, mesmo que bem brasileira. Ainda, o apelido reforça características de imprecisão que virão depois: ele vive em moradia precária, sem endereço certo e, talvez, sem documento, é um típico trabalhador precário e informal.

A sua moradia é também imprecisa: "num barracão sem número", exceto pela contração da preposição "em" com o artigo definido "o" que antecede o "morro da Babilônia", lugar do 
Rio de Janeiro, que, no poema, em contraste com a Lagoa Rodrigo de Freitas, simboliza a pobreza.

Outra característica importante é o trabalho informal e braçal (carregador de feira livre), o situa na contradição da cidade urbanizada, além de ser um trabalho desvalorizado em relação ao trabalho intelectual em um país marcado por anos de escravidão. O trabalho também o coloca como qualquer um na cidade grande.

Toda essa imprecisão já mostra o caráter de síntese do personagem. Mas também o seu nome, o seu local de moradia, o fato de ser um trabalhador informal e braçal destacam-no como um personagem característico de classe social baixa.

Arrigucci (1990), em análise desse poema na obra Humildade, paixão e morte, destaca a contradição existente entre o alto e o baixo no poema. João Gostoso desce do alto da cidade (morro da Babilônia) para morrer na Lagoa Rodrigo de Freitas, o que relaciona a pobreza e a riqueza, o começo e o fim, a vida e a morte - contradições limites que são fundamentais na vida de qualquer pessoa. Os efeitos do desequilíbrio social que o desenvolvimento da urbanização acarretou, comentados por Sérgio Buarque de Holanda (1963), estão nessa contradição que nos leva à possibilidade de ver a cidade do Rio de Janeiro, que, paradoxalmente, tem no alto a classe social mais baixa, e, no baixo, a mais alta.

O crítico citado erroneamente aproxima João Gostoso do malandro carioca, relacionado à sua vida boêmia marcada no poema e ao desdobramento do apelido Gostoso:

O adjetivo gostoso distingue o indivíduo por uma forma de consideração pelo grupo social, conotando um matiz erótico e popular, com seu lado meio gaiato, que faz logo imaginar o universo do malandro, cuja força de tração e poder de sedução têm decerto um fundo sexual importante. Essa característica se liga, sem dúvida, coerentemente, prenunciando-a, à inclinação do malandro para a diversão e a festa, a que se entregará em seguida, num espaço igualmente apropriado a seu caráter: o bar. (ARRIGUCCI, 1990, p. 111).

João Gostoso não é um malandro, não há elementos no poema que sustentem a aproximação feita por Arrigucci, já que uma característica importante no personagem é o trabalho braçal, algo que o malandro rejeita. Além disso a inclinação para a diversão e a festa do malandro tem certa continuidade, algo inexistente no poema: "Uma noite ele chegou no bar Vinte de Novembro", e não todas as noites.

$\mathrm{Na}$ verdade, sendo uma poesia de projetiva realista, a poesia de Bandeira, ao retirar algo da vida, amplia-o e consegue sintetizar um movimento maior de vida, no destino individual de um personagem, encontra-se algo mais geral. Não é só João Gostoso carregador de feira livre 
que morava no morro da Babilônia num barracão sem número: ele sintetiza a problematização do destino do pobre em uma cidade marcada pela dicotomia da modernidade do Brasil, que produz a modernização através da reprodução e do aprofundamento sistemático da desigualdade de classes.

É necessário compreender que o caráter contraditório do progresso, que se dá pelo preço que alguns têm de pagar por esse avanço, está no poema, evidenciando uma relação violenta presente nas cidades brasileiras e no seu processo de urbanização: modernizaçãodesumanização. Violência que é cotidiana nessas cidades, o que confirma a contradição do progresso. Dessa forma, “o progresso humano é contraditório porque todo avanço pressupõe o sacrifício de alguns indivíduos, classes, culturas e nações.” (BASTOS, 2014), tal contradição do progresso também se relaciona ao progresso brasileiro.

O poema sintetiza essa violência na contradição humanização e desumanização. O texto parte da desumanização presente na caracterização genérica e na notícia de jornal e, a partir disso, humaniza João Gostoso. Essa humanização acontece nos versos centrais, marcados por verbos no pretérito perfeito (Bebeu/ Cantou/ Dançou), mostrando um pequeno espaço em que o sujeito viveu e ações que envolvem algo festivo e alegre, mais relacionado ao coração do que à razão. Apesar de ser um desdobramento do caráter festeiro citado por Arrigucci, são nesses versos, por meio das ações, que o sujeito deixa de ser apenas uma descrição genérica. Nesses versos que também se pode encontrar uma possível identificação com o leitor, que bebe, canta, dança e vive.

É interessante notar que as estrofes longas se aproximam mais dessa notícia de jornal, meramente informativa, e que é, nas estrofes mais curtas, que essa humanização, em que está presente as ações do João Gostoso, aparece, o que nos leva a ver o curto espaço do lirismo e da experiência na cidade moderna. Os três versos compostos apenas por verbos de ação estão, ainda, na estrutura do poema, demarcados, e sufocados, pelos versos mais longos, o que culmina na metáfora do afogamento em um poema em que o sujeito, assim como o sujeito brasileiro, busca um espaço de sobrevivência numa cidade que deixa pouca alternativa, no sentido em que a vida do sujeito é arrastada pelo cotidiano na cidade moderna.

Como foi observado, tudo é marcado sem pontuação final, conotando uma continuidade inevitável, em que os acontecimentos vão se sucedendo até chegarem no último verso, o único que apresenta marca de pontuação, um ponto final, que marca o fim da narrativa e a morte por afogamento do personagem. Fica sugerida a falta de saída de sua vida:

Depois se atirou na lagoa Rodrigo de Freitas e morreu afogado. 
A progressão trágica, o sufocamento e uma ideia de cotidiano nos remetem às reflexões sobre o cotidiano no contex to capitalista feitas no capítulo 1 , uma vida cotidiana em um mundo que passou a ser muito mais fragmentado e o tempo muito mais mecanizado, levando a uma lógica de repetição e alienação. O que, citando mais uma vez Wilson Flores, "não provoca reação organizada, e sim paralisia, medo e sensação de impotência. Tudo parece surgir como fatalidade, como fato consumado, como algo diante do qual não há nada a fazer” (FLORES, 2012).

No poema, tudo parece ser organizado segundo uma progressão lógica, João Gostoso, que vive à margem da sociedade, vai sendo guiado, mecanicamente, para a morte por afogamento, que parece um destino coerente. Mesmo em suas ações que, a princípio, o humanizam, há a sensação de impotência, de sufocamento diante desse cotidiano sufocante da cidade moderna, que é observado criticamente por esse poeta moderno brasileiro.

Além desse aspecto mais geral envolto no cotidiano da cidade em processo de modernização, o poema evidencia questões de classe, por meio da violência que é parte do processo de urbanização e é sintetizada no poema na figura de João Gostoso e das suas características genéricas que o situam à margem da sociedade. A violência faz parte do "homem cordial", que tem raízes na violência das senzalas, e a perpetuação da violência prossegue no conflito marcado pelo destino trágico, que parece coerente, do pobre João Gostoso.

É significativo notar ainda que, para um certo senso comum a respeito do país, o brasileiro é conhecido por sua alegria (plasmada no poema talvez pelo "beber, cantar, dançar”). Porém, no poema evidencia-se que é uma alegria que se relaciona com uma melancolia. Como comentado no capítulo 1, a alegria caracteristicamente brasileira pode ser entendida como algo que revela essa melancolia, compensando uma miséria melancólica relacionada à submissão vinda da nossa história de colonização e escravidão.

No poema, é possível ver o país da alegria e da dança em uma perspectiva mais crítica, as ações caracterizadas como alegres estão também sufocadas porque, no espaço do poema, como falado, os versos "Bebeu/Cantou/Dançou", que compreendem versos de alegria e festa, estão sufocados pelos versos maiores, marcados pela miséria característica de João Gostoso, que se relaciona com a sua condição social, e pelo seu encontro trágico com a morte.

Todos esses aspetos levantados nos levam a ver que este poema responde ao processo modernizador, que teve como caraterística a exclusão social das camadas mais pobres, de forma a acentuar o desequilíbrio social acarretado pelo desenvolvimento da urbanização, e, além 
disso, sintetiza, com a morte por afogamento, o sufocamento do sujeito no cotidiano da cidade moderna.

Sérgio Buarque de Holanda sintetiza a cordialidade como efeito desse desequilíbrio social resultante da modernização tardia e, na cidade moderna do poema, essa noção que aborda a contradição entre modernidade e valores do passado rural e colonial não deixa de aparecer, está no nome João Gostoso, evidenciando a disciplina de simpatia do "homem cordial", além de pressupor uma maior familiarização. Também, no choque produzido com a contradição notícia e poema, envolvendo a experiência do leitor, parece buscar algo positivo de uma cordialidade brasileira: a empatia.

Mas no afogamento, não há conciliação, como quer um "homem cordial" com um fundo emotivo transbordante, há morte, há conflito. Assim, a forma de responder ao processo modernizador brasileiro é da própria situação histórico-social do país e do conflito envolto no avanço do progresso da urbanização da época, exibindo algo que fica à margem disso: João Gostoso, que mergulha e vive a história trágica, está à margem das instituições, não tem registro, o sobrenome é substituído por um apelido cordial, suas características não o humanizam.

Assim como o personagem, que fica à margem, cantando, bebendo e dançando, o próprio poema, que parte de uma notícia de jornal, também está à margem, mesmo não se convertendo à notícia, recolhe a linguagem dela e se situa, cordialmente, entre a literatura e a notícia.

\subsubsection{Um mundozinho no Rio de Janeiro}

As crônicas de Bandeira geralmente são voltadas para cidades que guardam, por meio da arquitetura ou dos fatos, aspectos considerados mais coloniais, como cidades de Minas Gerais com suas igrejas ou as do Nordeste com os casarões. O Rio de Janeiro também faz parte das crônicas bandeirianas, sendo evidenciada a cidade que a um só tempo é moderna e provinciana, para isso, o cronista utiliza muito da infância.

Um exemplo é a crônica "A trinca do Curvelo". Esse texto, publicado pela primeira vez em 1932, trata do bairro carioca de Santa Tereza, no qual há uma área conhecida como Curvelo. O começo da crônica é uma explicação do que seria trinca e uma limitação sobre o que o texto vai tratar: um "mundozinho irresponsável dos piores malandros da terra..."

Trinca são três cartas do mesmo valor no baralho. Mas, na crônica, interessa falar da trinca do Curvelo, que é o conjunto da molecada da rua. O diminutivo "mundozinho" indica 
ironia que o restante do período do parágrafo acima confirma. O cronista vai se atentar, no espaço da crônica, ao mundo dos malandros, que, na verdade, são as crianças do Curvelo.

A infância ali retratada tem alguma relação com a de "Evocação à Recife", já que os meninos quebravam as janelas do cronista tal como o eu-lírico desse poema "partia as vidraças da casa de dona Aninha Viegas". Já vimos no capítulo 1 deste trabalho, como a infância na obra de Bandeira representa um momento mais provinciano do Brasil. Não só em "Evocação do Recife", em que o saudosismo da infância traz a presença de um Brasil patriarcal na modernidade, mas em outros comentados neste trabalho, como "Camelôs", em que percebemos a infância, a partir do contraponto feito com a vida adulta, representando algo provinciano mesmo na cidade. Nesse poema, o afeto em relação a essa infância destaca a permanência de um mundo tradicional patriarcal na vida modernizada, urbanizada e mecanizada.

Na crônica, a matéria literária novamente, mesmo que no Rio de Janeiro da década de 30, centra-se em um bairro pobre e na infância que existe naquele bairro. Traz a infância em contraponto com a vida adulta, o que se percebe com as características de adultos atribuídos ironicamente, de forma exagerada, às crianças: "os piores malandros", "o microcosmo da política", "Salvo o homicídio com premeditação, são capazes de tudo" "mentir é com eles".

O contraponto continua em relação ao personagem Lenine, uma criança do lugar, mas cujo nome nos remete ao revolucionário comunista e político russo. A referência se confirma e a ironia se dá com as características do garoto, a discussão se torna política, mas com uma linguagem infantil e considerando uma inocência da criança, além disso, "a trinca não tem lá grande respeito por Lenine", formando também uma imagem irônica da figura histórica. O contraponto está presente também no fato de uma discussão normalmente considerada de adultos ser atribuída à criança, rebaixando aquela discussão pertinente na época, assim, o que o cronista desejava era a inocência da infância:

(...) Lenine, cujo o sonho mais caro é o comunismo integral. Tem sete anos apenas, mas já me considera um infame pequeno-burguês, só porque eu nunca lhe quis dar uma fita métrica de aço que um dia viu sobre a minha mesa. Toda vez que eu defendo, a propósito de um livro, de um canivete, de um isqueiro cobiçado por Lenine, o princípio da propriedade, Lenine branda com um "toque de mal" e vai se vingar na minha porta, contra a qual investe a pontapés e pedradas. O grito de guerra é: "Vou es... bodegar a sua porta!". (BANDEIRA, 2005, p. 150).

É interessante também notar um afeto que é construído pelas crianças do lugar, principalmente por Lenine, "a criança de peito da trinca" e que tem uma outra crônica com seu nome, "Lenine". O diminutivo em um tom afetivo também aparece: “crioulinho José Antônio 
Bento Marinho", “o Encarnadinho", "o mulatinho Ivan”, um uso que vai muito além de indicar a pequena estatura das crianças, indica afeto, mas também ironia, já que se relaciona à cor de pele das crianças. O afeto também se esclarece na participação do narrador na brincadeira das crianças, brincadeira que também faz contraponto com a vida adulta: "Ao mulatinho Ivan dei, como de direito, o cognome de Terrível. Batem à minha janela. - "Quem é?" - "Ivan" - "Que Ivan?" - "Ivan, o Terrível!" Foi assim que ensinei a me responder." (BANDEIRA, 2005, p. 150). Assim, há a presença forte de uma voz com uma impressão afetiva.

Dessa forma, a linguagem da crônica e os acontecimentos têm algo de inocente e infantil que pode ser aproximado a um estado mais provinciano do Brasil, ou seja, a um aspecto mais rural e mais distante da vida moderna da cidade grande, assim como o eu-poético aproxima a infância da permanência de algo provinciano na cidade em "Camelôs". Para Sylvia Tamie Anan, "a ingenuidade infantil encarnada em Lenine, que não tem consciência do que o seu nome pode representar, é comparada à ingenuidade do ambiente provinciano do morro." (ANAN, 2006, p. 47). Ainda: "Lenine representa a própria vida do Curvelo, que se identifica com essa vida de província tão aproximada por Bandeira e "estragada" pela política." (ANAN, 2006, p. 50).

Esse ambiente mais provinciano é o ambiente que o narrador cria em sua crônica com brincadeiras infantis que, de alguma forma, o lembram a infância na sua província. Cria um mundo dele, provinciano, e privado, no Rio de Janeiro. Nesse mundinho, vê-se um pouco de síntese do Brasil em sua conhecida mistura: "a trinca é rica em tipos bem diferenciados pelo físico, pela cor, pelo caráter”, com seus tipos caracterizados desde o começo como malandros, o que continua com uma esperteza cínica: "também eu tirei o corpo fora e ela deu com a mão na parede que chega destroçou os dedos.” (BANDEIRA, 2005, p. 151).

No contraponto entre a vida adulta e a infância, há a preferência por esta última: “A impressão que se tem é que ficando homens vão todos dar assassinos, jogadores, passadores de notas falsas... Pois nada disso. Acabam lutando pela vida, só com a saudade do único tempo em que foram verdadeiramente felizes.” (BANDEIRA, 2005, p. 149; grifo nosso).

Nessa impressão que a citação comenta, encontra-se também o que foi discutido em "Poema tirado de uma notícia de jornal", um destino encaminhado pelo ritmo do poema como inevitável, o destino é o sufocamento, além de discutir o condicionamento do caráter pelas circunstâncias.

A impressão se justifica pela vida difícil em um bairro pobre da cidade moderna, e não, como quer propor o texto, pelas brincadeiras de crianças que os fazem, "salvo homicídio com premeditação", ser capazes de tudo, "até de partir as vidraças das minhas janelas", ao que o 
"até" reforça a ironia e a atribuição a brincadeiras infantis, confirmadas com a referência à "Evocação do Recife".

Apesar de o cronista afastar o destino de "assassinos, jogadores, passadores de notas falsas...", e muitos outros destinos que o leitor poderia pensar por causa da presença das reticências, o sentido de sufocamento do cotidiano mercantilizado da cidade moderna visto em "Poema tirado de uma notícia de jornal" está no parágrafo seguinte:

Para muitos a luta começa com uma extensão da pagodeira da trinca. Vender os jornais da tarde, "xepar", isto sim que é divertido, já sendo atividade de homem: - "A Noite! O Globo! O Diário! Qual é?". Voltar às onze horas da noite para casa, trazendo cinco, seis, sete mil-réis. Sustentando a família com treze e quatorze anos... Mas no dia que traz só três mil e tanto é que vadiou. Malandro. Te boto na Colônia!" Então começa a perceber que a vida não é brinquedo, como na trinca. (BANDEIRA, 2005, p. 150).

Esse parágrafo se contrapõe ao último período do parágrafo anterior, "a saudade do único tempo em que foram verdadeiramente felizes", já que parece ser uma saudade muito mais da infância bandeiriana do que dos meninos do Curvelo, que muito cedo começam a trabalhar. Além de revelar que o cronista não é ingênuo.

Há, pelo descrito dessa crônica, a dialética entre um mundo provinciano decadente, retratado na infância, e da vida modernizada, urbanizada e mecanizada, que é observada pelo olhar crítico do cronista. O olhar se torna também melancólico, melancolia que se confirma no último acontecimento narrado na crônica:

Tenho pena de não ver hoje na trinca o Panaco. Panaco era o Olavo, irmão desse Àlvaro. Criado nu na rua. Uma saúde de ferro e já andava. Era a borboleta do Curvelo. Sarampo bateu nele. A mãe estava no emprego. Os irmãos entenderam de lavar o quarto. Panaco apanhou um resfriado, e lá se foi para a trinca dos anjinhos de Nosso Senhor! (BANDEIRA, 2005, p. 151).

A melancolia está no conhecido encontro com a morte e com a associação da Trinca do Curvelo e da Trinca dos anjinhos do Nosso Senhor, além da inocência infantil, está presente o sofrimento que se revela partícipe da vida dessa gente do Curvelo.

A vida na cidade moderna é problematizada com uma pobreza, que aparece discretamente, com o destino marginalizado esperado, o trabalho que começa cedo, em contraste com a não menção dos estudos e essa morte inocente retratada no final. Nesses aspectos e com essa problematização que a crônica responde ao processo de modernização de forma problematizada. Assim como no contraponto da infância com a vida adulta, e na presença 
de uma ingenuidade infantil em contraponto com o cotidiano sufocante da cidade urbanizada. Essa ingenuidade está na própria voz narrativa ao se colocar como partícipe das brincadeiras e do cotidiano dos meninos que observa.

Como é comum em Bandeira e no gênero crônica, no texto, o olhar é voltado, aparentemente, para acontecimentos menores, como o cotidiano pobre dos meninos do Curvelo. Para Arrigucci, em "Fragmentos sobre crônicas":

Através de figuras singulares do seu convívio, o cronista conta agora fragmentos de uma história menor, aquém dos grandes acontecimentos, vivida no dia a dia da Cidade Maravilhosa: o Rio dos meninos pobres do morro do curvelo, do mundo noturno do samba, das rodas boêmias da Lapa, do intelectuais modernistas. A crônica se situa bem perto do chão, no cotidiano da cidade moderna, e escolhe a linguagem simples e comunicativa, o tom menor do bate-papo entre amigos, para tratar das pequenas coisas que formam a vida diária, onde às vezes encontra a mais alta poesia. (ARRIGUCCI, 1987, p. 55).

Essas características de crônicas bandeirianas se ligam à construção poética e ambivalente da sua humildade, assim como à familiaridade com o leitor, que, como foi discutido no capítulo 1 desta pesquisa, envolve aspectos cordiais. A crônica aqui trabalhada também se relaciona com a cordialidade com um narrador que desenvolve um afeto por aquelas crianças em um convívio tão familiar e tão íntimo com elas, o que faz parte do mundo que ele cria. Afinal, "o desconhecimento de qualquer forma de convívio que não seja ditada por uma ética de fundo emotivo representa um aspecto da vida brasileira" (HOLANDA, 1963, p. 140). Como falar, então, da pobreza e dos dilemas que invadem o processo de modernização? Estabelecendo uma forma de convívio de fundo emotivo, uma sociabilidade cordial, nas suas observações de cronistas, fazendo parte do mundo de brincadeiras das crianças do morro, envolvendo o leitor e o remetendo a uma saudade muito característica da obra bandeririana como um todo: a infância.

\subsection{Tão cordial}

Conforme foi analisado, as imagens de cidades, modernas ou provincianas, construídas em poemas e crônicas sugerem aspectos relacionados à cordialidade, em função de um olhar crítico à modernização e à urbanização, que no Brasil sempre se deu de forma problemática e com favorecimento considerável dos setores dominantes, o que acentua a desigualdade de classes e a presença de elementos do passado colonial. 
Essa presença continua em outros poemas de Libertinagem e em outras crônicas de Crônicas da Província do Brasil, como mostrarão as análises de "Irene no céu", "Não sei dançar", "Velório" e "Bahia", no trato de alguns expedientes cordiais.

Destaca-se que esses textos são considerados modernistas, momento da literatura brasileira em que, como vimos, a temática do nacional reaparece fortemente. Vale lembrar que tal temática também foi central no Romantismo, momento em que, na busca de proclamar as especificidades nacionais para construir uma Identidade Nacional, os intelectuais e os escritores, influenciados principalmente pelo romantismo francês, pretendiam "ao fim do caminho, encontrar a civilização europeia” (RICUPERO, 2004, p. XXVIII), ou seja, realizaram o desejo de criação de identidade em moldes europeus. Com isso, aparecem contradições, como o apagamento da maioria da população (pobres e escravos), que representavam aspectos da realidade social brasileira que escapavam a esse molde de civilização.

No Modernismo, conforme foi comentado no capítulo 1 deste trabalho, há uma perspectiva mais crítica em relação aos recalques históricos, com a adesão desses componentes antes não aceitos. Assim, ganha força o interesse por novos olhares para a realidade do país, olhares que colocam em cena esses elementos antes excluídos, como a questão do negro, que começa a aparecer como sujeito social, explicitando uma discussão de raça e de classe.

Essa questão se faz presente, por exemplo, na discussão de "Evocação do Recife" e da Crônica “O que era o Pernambuco de 1821”, com a preta das bananas, por exemplo. E está presente no poema "Irene no céu" de forma bem cordial porque dilemas que envolvem essa questão são apresentados para o leitor de forma sutil, trabalha-se liricamente com eles, mas o que se revela é a ambiguidade, assim como acontece em relação ao conceito da cordialidade discutido no capítulo 2 desta pesquisa, há uma violência de fundo naquilo que, na aparência, é apenas um envolvimento afetivo.

\subsubsection{Irene em um céu brasileiro}

O poema "Irene no céu" tem sete versos, divididos em duas estrofes que parecem dividir o poema em duas partes distintas. A primeira é uma caracterização de Irene, figura central do poema, cujo nome se repete em cinco dos sete versos. A segunda parte mostra Irene no céu em uma conversa com São Pedro. Tudo com uma linguagem simples e aproximada do prosaico. A figura do negro, por meio de Irene, é destaque nesse poema, o que, como vimos, começou a acontecer principalemnte a partir do Modernismo com o projeto de um novo olhar para a nossa história e país que considera a questão do negro. O poema, entretanto, é sobretudo irônico 
porque parece trasmitir essa questão de forma harmônica, mas, na verdade, a problematiza de forma súltil, já que é uma questão que não se desenvolve com harmonia na sociedade:

\section{Irene no céu}

Irene preta

Irene boa

Irene sempre de bom humor.

Imagino Irene entrando no céu:

- Licença, meu branco!

E São Pedro bonachão:

- Entra, Irene. Você não precisa pedir licença.

(BANDEIRA, 2009, p. 142)

"Irene no céu" apresenta algo de harmonioso, por meio da simplicidade vocabular e sintática, da relação com algo celeste, marcado pelo adjunto adverbial de lugar "no céu", da repetição do nome próprio e da dicção aproximada da fala popular no diálogo entre Irene e São Pedro na segunda estrofe. Tal diálogo também revela intimidade e afeto. Além disso, Irene é uma personagem que integra a mitologia pessoal do poeta, tem a força simbólica de ser algo aparentemente íntimo e pessoal. Tudo isso parece criar uma empatia com o leitor e resulta em um tom poético mais ameno e harmonioso.

Esse tom, entretanto, pode ser visto como parte da construção da ironia do poema. É significativo que essa simples e afetuosa conversa de Irene com São Pedro traga explicitamente a escravidão e, assim, uma violência de fundo, a primeira característica apresentada de Irene (ser preta) é seguida por características que recuperam uma atmosfera docilmente serviçal, "boa" e "de bom humor", acompanhadas pela fala de pedir licença. O olhar para Irene parece, assim, ser do senhor em relação a um serviçal, que, segundo esse ponto de vista, teria de apresentar um bom humor subserviente.

O verso "Irene Preta" ainda traz relação com a "mãe preta", a serviçal, "parte da família”, que faz parte da organização social brasileira com profundas raízes na escravidão. Essa figura, que pressupõe a afetividade do eu lírico, não é um dado particular, mas faz parte do imaginário do Brasil.

Dessa forma, a harmonia do poema e as qualidades de Irene, assim como sua entrada no céu, escondem uma violência que está estritamente relacionada com um mundo de serviço e uma recuperação da escravidão, confirmada na antítese "preta" e "branco". O passado colonial se faz presente em um poema em que a voz lírica atrai o leitor de forma bem cordial pela simplicidade harmônica. 
Mesmo com a relativa autonomia de Irene, cordial também é a atitude de São Pedro na ordem "entra, Irene, você não precisa pedir licença", reforçada pelo adjetivo bonachão. Tudo isso mostra que, em oposição à aparente dimensão conciliatória, há a expressão de uma realidade não harmoniosa e inconciliável que insiste em persistir até depois da morte, com Irene indo ao céu. A atitude cordial, na nossa história, disfarça a violência da esfera de produção, assim como foi comentado, em relação ao favor, por Roberto Schwarz no capítulo 2 deste trabalho.

Como já abordado neste trabalho, a professora Maria Odila Leite da Silva Dias (1998), em "Política e sociedade na obra de Sérgio Buarque de Holanda", destacou o "homem cordial" como "eventualmente violento e anárquico", e associou a cordialidade a uma preocupação da elite de manter uma aparente harmonia, que esconde uma violência de fundo. É essa harmonia que se faz presente no espírito bonachão de São Pedro, que se faz agradável, mas esconde uma violência que é histórica e tão brasileira. Dialeticamente, o tom agradável de São Pedro ao mesmo tempo que esconde a violência, a revela. O poema a esconde exatamente para revelar. A violência está nessa harmonia aparente que revela subtendida a nossa sociedade patriarcal.

Apesar de o poema, em um primeiro momento, parecer apontar para a leitura conciliatória do merecimento do céu, o aparentemente simples capta a realidade complexa brasileira, atravessada por uma violência historicamente conhecida, persistente até no céu. Violência que se esconde no espírito bonachão de São Pedro, mas se revela no poema. No céu, a dinâmica social não muda, a figura do senhor e do trabalho servil permanecem.

Para Sérgio Buarque de Holanda, em Raízes do Brasil, "toda ordem administrativa do país, durante o império, e mesmo no regime republicano, tem elementos estreitamente vinculados ao velho sistema senhorial" (HOLANDA, 1963, p. 78). Esse movimento da história nacional é captado no poema, que, na modernidade, e ironicamente até no céu, tem elementos estreitamente vinculados ao velho sistema senhorial.

Mara Ferreira Jardim, ao analisar o poema, apresenta um dado sobre Irene que se faz significativo para análise trabalhada aqui:

Em entrevista concedida a Paulo Mendes Campos, Bandeira revela a identidade de Irene, que não se trata, como querem alguns críticos, de mais uma figura trazida da infância, mas da arrumadeira de sua casa no Rio. (JARDIM, 2007, p. 106). 
O poema, para um leitor de Bandeira, dado o contexto do livro, leva a crer que se trata de mais um personagem da sua infância. Isso apesar de no Itinerário ou em outro texto que se apresenta a sua mitologia relacionada à infância não remeter Irene.

Irene, mesmo parte dessa realidade factual, é personagem literária da obra de Bandeira, pensando com Arrigucci, “Irene, Rosa, Dona Aninha Viegas, Totônio Rodrigues e várias outras pessoas da roda familiar e do ciclo de amizades do poeta, têm a consistência ambígua dos seres feitos de palavras e imaginação. " (ARRIGUCCI, 1999, p. 50)

Na crônica "Ecos de Carnaval", de Flauta de Papel, o narrador também contextualiza Irene, recuperando partes do poema ("Irene preta. Irene boa e sempre de bom humor") e a colocando como personagem serviçal do Manuel Bandeira adulto no Rio de Janeiro. Nela, há algo da vivência do popular e a problematização do Carnaval: "Passava ela o ano inteiro juntando dinheiro para gastar no Carnaval (...). Quarta-feira de cinzas, às oito da manhã, estava à minha porta para o serviço".

Irene, como personagem real, faz parte do morro do Curvelo. Na crônica, há a discussão da trabalhadora pobre e, com isso, uma perspectiva mais crítica em relação ao Carnaval. Todavia, no poema, sua existência ficcional discute também, a partir desse dado de que Irene faz parte de um lugar e época mais urbanizado no Brasil, a discussão da história marcada pela escravidão, velada não só no céu do poema, mas também em uma cidade brasileira urbanizada. Já que o poema, em contradição, recupera toda uma atmosfera serviçal e escravocrata da época colonial. O poema com essas profundas ambiguidades não é uma defesa da escravidão, mas a revelação da realidade de um Brasil em que se faz presente os desdobramentos da escravidão.

Somado a isso, outro aspecto parte da lógica colonial brasileira é evidenciado: São Pedro é uma imagem bem brasileira, principalmente se pensarmos nas festas juninas, mas é relacionada à religião europeia imposta pela violência etnocêntrica da colonização. A preta Irene, no poema, já faz parte dessa religião já bem brasileira, mas que tem bases europeias e no que foi imposto aos escravos, índios e negros.

Mais do que isso, com a figura humanizada de São Pedro, marca de simplicidade e informalidade, e a construção do diálogo muito popular entre a preta Irene e São Pedro, com, por exemplo, a expressão popular "meu branco", indica um cristianismo que Sérgio Buarque classifica como brasileiro e cordial:

O desconhecimento de qualquer tipo de convívio que não seja ditada por uma ética de fundo emotivo representa um aspecto da vida brasileira que raros estrangeiros chegam a penetrar com facilidade (...). Nosso velho catolicismo, tão característico, que permite tratar os santos com uma intimidade quase 
desrespeitosa e que deve parecer estranho às almas verdadeiramente religiosas, provém ainda dos mesmos motivos. (HOLANDA. 1963, p. 141).

No capítulo 1, exemplificou-se, com outros poemas, o processo segundo o qual Manuel Bandeira transforma em matéria poética esse catolicismo que faz uma transposição do "horror às distâncias que parece constituir, ao menos até agora, o traço mais específico do espírito brasileiro" (HOLANDA, 1963, p. 141), como em “Oração a Teresinha do Menino Jesus": "Quero Alegria! Me dá Alegria!/ Santa Teresa!/ Santa Teresa não, Teresinha.../ Teresinha... Teresinha.../ Teresinha do menino Jesus.” (BANDEIRA, 2009, p. 138).

Considerando o que foi exposto, a realidade histórica colonial está presente, assim como a vida social marcada por uma importância ao emotivo, aspectos presentes e sintetizados no "homem cordial". Tais aspectos permanecem na modernidade. A cordialidade está como aspecto formal no poema, que, assim como São Pedro, cordialmente e harmoniosamente, apresenta essa discussão e a violência. Na construção dessa harmonia e usando dessa familiaridade do trato cordial, que, apenas aparentemente, desfaz diferenças, o poema parece querer criar empatia com um leitor para tratar dessa permanência da violência, captando uma cordialidade que o leitor pode ter, mas nem percebe.

O desfecho do poema, levando em conta essas considerações, não deixa de ser ambíguo e irônico: "Entra, Irene. Você não precisa pedir licença". Ironia que demonstra a afirmação de Jerônio Teixeira em Drummond Cordial: "Sérgio Buarque não denuncia, mas tampouco nega a violência. O "homem cordial” seria impensável sem o estigma fundamental da civilização brasileira - a escravidão. A cordialidade não é estranha ao que Sérgio Buarque chama de 'moral das senzalas" (TEIXEIRA, 2005, p. 31). Tal moral é caracterizada como sinuosa até na violência, pressuposta nos fundamentos do laço social representado por esse poema tão "cordial".

O poema, então, liga-se à cordialidade muito além dos aspectos cordiais representados, como na informalidade do cristianismo brasileiro e cordial, a caracterização de São Pedro e sua fala cordial. É cordial porque torna possível discutir uma forma cordial. De forma muito sutil, capta o leitor que pode se perceber cordial, assim como o São Pedro do poema.

O poema é, dialeticamente, harmonioso e violento. A cordialidade, assim como não deve ser entendida como algo apenas positivo, não é um dilema histórico essencialmente negativo. A empatia, a intimidade, o favor e outras características que envolve o "homem cordial" não são ruins à princípio, mas há problema em o espirito bonachão de São Pedro ser 
norma nas relações de trabalho ou justificar a violência característica das relações serviçais do nosso passado colonial, reforçando as desigualdades.

Dessa forma, o poema, com tudo que foi discutido, realça não só a violência da nossa colonização, mas, com essa forma cordial que busca o leitor, responde ao processo de modernização que, no Brasil, deu-se em profunda relação do presente com o passado. O poema traz uma equivalência do passado e do presente, salientada pela figura servil de Irene, e realça uma realidade presente que apresenta uma permanência de dados do passado.

\subsubsection{Um "tomar alegria" tão brasileiro}

No poema "Não sei dançar", o Brasil é apresentado com a mediação de uma festa de Carnaval, identificado pela conhecida metáfora "baile de terça-feira gorda". Essa festa, caracterizada muitas vezes por uma alegria exagerada, ganha um tom melancólico e irônico no poema:

\section{Não sei dançar}

Uns tomam éter, outros cocaína.

Eu já tomei tristeza, hoje tome alegria.

Tenho todos os motivos menos um de ser triste.

Mas os cálculos das probabilidades é de uma pilhéria...

Abaixo Amiel!

E nunca lerei o diário de Maria Bashkirtseff.

Sim, já perdi pai, mãe, irmão.

Perdi a saúde também.

É por isso que sinto como ninguém o ritmo do jazz-band.

Uns tomam éter, outros cocaína.

Eu tomo alegria!

Eis aí por que vim assistir a este baile de terça-feira gorda.

Mistura muito excelente de chás...

- Não, foi arrumadeira.

Esta foi açafata...

E está dançando com o ex-prefeito municipal.

Tão Brasil!

De fato este salão de sangues misturados parece o Brasil...

Há até a fração incipiente amarela

$\mathrm{Na}$ figura de um japonês.

O japonês também dança maxixe:

Acugêlê banzai!

A filha do usineiro de Campos

Olha com repugnância 
Para a crioula imoral.

No entanto o que faz a indecência da outra

É dengue nos olhos maravilhosos da moça.

E aquele cair de ombros...

Mas ela não sabe...

Tão Brasil!

Ninguém se lembra de política...

Nem dos oito mil quilômetros de costa...

O algodão do Seridó é o melhor do mundo?... Que me importa?

Não há malária nem moléstia de Chagas nem ancilóstomos.

A sereia sibila e o ganzá do jazz-band batuca.

Eu tomo alegria!

(BANDEIRA, 2009, p. 125)

No capítulo 1 deste trabalho, já foram feitos comentários sobre a alegria característica brasileira e a melancolia existente por trás dela, numa dialética muito bem sintetizada na tese “Manuel Bandeira: Tão Brasil” de Mara Ferreira Jardim (2007). Sabe-se que, na criação da nossa Identidade Nacional, vários símbolos do país foram utilizados, e abastecidos com boa dosagem de idealização, como a natureza exuberante, o índio relacionado ao mito do bom selvagem. Tais símbolos, muitas vezes, foram utilizados para compensar um atraso material e uma miséria que tem estrita relação com nossa situação colonial, ao que Antonio Candido (2000), em "Literatura e subdesenvolvimento", chamou de "ilusão compensatória".

A alegria atribuída ao brasileiro, traço identitário tão importante e observável pelos estrangeiros, também pode ser concebida como uma ilusão compensatória. Ela compensa uma melancolia que se relaciona à permanência do atraso, de nossa situação colonial, materializada, por exemplo, na desigualdade social brasileira. No Carnaval, essa alegria que revela uma melancolia fica evidente, sendo uma manifestação popular em que cada pessoa pode, nos dias que dura a festa, fantasiar-se e inverter papeis sociais de uma ordem cotidiana pautada nas diferenças de classes e raças. O Carnaval parece romper essa ordem, sendo conhecido também como uma mistura de povos, mas, na verdade, a evidencia, como nos mostra o poema na estrofe que fofoca da dança da arrumadeira com o prefeito:

Esta foi açafata...

- Não, foi arrumadeira.

E está dançando com o ex-prefeito municipal.

Tão Brasil!

No baile de Carnaval, a arrumadeira até dança com o ex-prefeito, mas as classes sociais não deixam de ser evidenciadas. Em Bandeira, essa festa tão brasileira e alegre assume uma 
tonalidade melancólica e uma perspectiva crítica também em vários outros textos, como nos versos do poema "Na boca", também de Libertinagem:

Sempre tristíssimas estas cantigas de carnaval

Paixão

Ciúme

Dor daquilo que não se pode dizer

[...]

(BANDEIRA, 2009, p. 140).

O Carnaval aparece frequentemente na obra de Bandeira através de um olhar mais crítico porque observa e revela a melancolia em uma festa que normalmente é retratada pela alegria. É assim também em "Não sei dançar". O tom irônico e melancólico já é anunciado no título, com essa negação, que vai justificar o eu-lírico que observa o baile de carnaval e que entra em contradição com os versos em que o eu-lírico afirma tomar alegria:

Uns tomam éter, outros cocaína.

Eu tomo alegria!

Eis aí por que vim assistir a este baile de terça-feira gorda.

O poema é dividido em duas partes. Nas três primeiras estrofes, há algo mais íntimo, que nos remete a uma vida melancólica, justamente pela negação irônica da tristeza:

Uns tomam éter, outros cocaína.

Eu já tomei tristeza, hoje tomo alegria.

Tenho todos os motivos menos um de ser triste.

Mas os cálculos das probabilidades é de uma pilhéria...

Abaixo Amiel!

E nunca lerei o diário de Maria Bashkirtseff.

Sim, já perdi pai, mãe, irmão.

Perdi a saúde também.

É por isso que sinto como ninguém o ritmo do jazz-band.

Uns tomam éter, outros cocaína.

Eu tomo alegria!

Eis aí por que vim assistir a este baile de terça-feira gorda.

Essa primeira parte é estruturada pela expressão da primeira pessoa e recupera, para o leitor de Manuel Bandeira, situações familiares que são construídas como matéria poética em sua obra. Situações pelas quais muitas vezes, pela mediação da morte e da doença, constroem- 
se melancólicas. No poema, ironicamente, o eu-poético rejeita a tristeza, já que tomar alegria é afirmar essa tristeza.

A partir dessas estrofes mais íntimas e subjetivas, chega-se à segunda parte do poema: a construção de imagens a que o eu-lírico assiste no baile de terça-feira gorda, que, conforme o próprio poema explicita, sintetizam o Brasil: "De fato este salão de sangues misturados parece o Brasil..."

Fala-se, então, da conhecida miscigenação brasileira, em uma mistura de raças e classes, tida por muitos como harmônica. Sendo outro fator de ilusão compensatória, pois a ideia de mestiçagem é tida como um elemento específico positivo do Brasil, dá a ideia de que o país se constituiu harmoniosamente quanto às relações de raça, mas há essencialmente, nessa sociedade híbrida, a violência que não é conciliatória da nossa sociedade colonial e que deixa marcas até hoje, o que é compensado com essa ideia de mistura de raças, presente, como foi discutido no capítulo 2, na obra de Gilberto Freyre. O poema fala dessa "mistura muito excelente de chás”, mas construído de forma melancólica, denuncia a não harmonia.

Não harmonia confirmada no preconceito por parte da filha do usineiro e pela caracterização da crioula como "imoral” na sétima estrofe:

Há até a fração incipiente amarela

Na figura de um japonês.

O japonês também dança maxixe:

Acugêlê banzai!

A filha do usineiro de Campos

Olha com repugnância

Para a crioula imoral.

No entanto o que faz a indecência da outra

É dengue nos olhos maravilhosos da moça.

E aquele cair de ombros...

Mas ela não sabe...

Tão Brasil!

Além do preconceito referencial desses versos, encontra-se muito da história brasileira que é marcada pelo conflito urbanizador e da permanência de estruturas sociais coloniais. É significativa, em relação a essa interpretação, a caracterização "usineiro de Campos”, a usina é uma metáfora que tanto pode simbolizar um estabelecimento industrial equipado de máquinas ou os engenhos de cana-de-açúcar, sendo açúcar um símbolo tão forte do nosso período colonial. Maxixe, a dança que o japonês pratica, também é significativa por ser uma dança urbana brasileira, nascida no Rio de Janeiro, que esteve tanto nos salões brasileiros e europeus no século XIX. 
O lado erótico da crioula remete ao Brasil colônia. Gilberto Freyre (1963) relaciona, em Casa-grande \& senzala, constantemente o erotismo e a sexualidade à nossa história de colonização, primeiro como algo que motivou a miscigenação entre as diferentes culturas e importante para o povoamento do território pelos colonizadores. A obra discute ainda o senso comum da relação sexualidade e o negro, Freyre (1963) aborda esse erotismo como uma consequência do tipo de organização social escravista, o que está presente nas relações dos senhores de terras e das escravas e com a iniciação sexual, desde muito cedo, dos filhos desses senhores:

\footnotetext{
Nas condições econômicas e sociais favoráveis ao masoquismo e ao sadismo criadas pela colonização portuguesa - colonização, a princípio, de homens quase sem mulher - e no sistema escravocrata de organização agrária do Brasil; na divisão da sociedade em senhores todo-poderosos e em escravos passivos é que se devem procurar as causas principais do abuso de negros por brancos, através de formas sadistas de amor que tanto se acentuavam entre nós; e em geral atribuídas à luxúria africana (FREYRE, 1963, p. 448)
}

Freyre (1963), nessa e em outras discussões de Casa-Grande \& Senzala, mostra o erótico presente no nosso processo de formação. No poema, o olhar repugnante para a crioula caracterizada como imoral remetem a essas discussões e à associação erótica ao crioulo. Além disso, nesse erotismo da “crioula imoral”, há muito da "moral das senzalas" abordada por Sérgio Buarque de Holanda, e já comentado neste trabalho: “À influência dos negros, não apenas como negros, mas ainda, e sobretudo, como escravos, essa população não tinha como oferecer obstáculos sérios. Uma suavidade dengosa e açucarada invade, desde cedo, todas as esferas da vida colonial.” (HOLANDA, 1963, p. 42).

Esse aspecto está presente nesses versos de Bandeira que, por meio das reticências, com o pensamento inconcluso, e do "cair de ombros...", reforçam o erotismo e a suavidade dengosa, sedutora, na própria forma do verso.

A presença de estruturas sociais coloniais em uma confusão de tempos também se dá em relação à dúvida de quem dança com o ex-prefeito municipal em estrofes anteriores ("esta foi açafata"). Açafata faz referência à família real, e até aos bailes europeus, já que significa a dama da corte que ficava encarregada das roupas das senhoras da família real. Todas essas contradições citadas que se situam tanto no passado colonial quanto no baile de Carnaval é que compõem os versos definidos pelo poema como "tão Brasil".

O verso "Tão Brasil", além de conferir uma marcação de ritmo ao poema, através da repetição, também evidencia a ironia da voz poética que observa criticamente esse baile de 
carnaval, o qual sintetiza o Brasil não só presente (significativamente os verbos do poema estão no presente) mas a permanência das raízes do passado no presente.

A última estrofe traz aquilo que esquecem nesse baile de Carnaval:

Ninguém se lembra de política...

Nem dos oito mil quilômetros de costa...

O algodão do Seridó é o melhor do mundo?... Que me importa?

Não há malária nem moléstia de Chagas nem ancilóstomos.

A sereia sibila e o ganzá do jazz-band batuca.

Eu tomo alegria!

É a alegria que esconde misérias, a política, as doenças (malária, moléstia de Chagas), o algodão do Seridó (produto rural brasileiro, mas que também destaca a industrialização, com a indústria têxtil). A alegria é mais uma vez ilusão, ao mesmo tempo em que é um componente da "liga social" brasileira, cordial.

Nessa estrofe, há uma conciliação de antagonismos comum ao brasileiro: “A conciliação de antagonismos e a tentativa de aproximar pessoas e objetos do coração fazem parte de um mesmo movimento" (TEIXEIRA, 2005, p. 50):

A sereia sibila e o ganzá do jazz-band batuca.

A sereia sibila, um elemento da mitologia greco-romana, o ganzá, instrumento de percussão tanto da cultura indígena quanto da africana, o batuque do jazz-band é uma estranha conciliação de opostos culturais. A estranha conciliação também se vê nos antagonismos históricos evocados pela contradição tempo presente e presença do colonial, essa conciliação é a própria cordialidade e é a contradição do Brasil em processo de urbanização. $\mathrm{O}$ eu lírico, portanto, parece assumir uma postura ambígua, que se aproveita do conciliatório para evidenciar o caráter postiço da conciliação.

O poema, em sua totalidade, com a primeira parte mais subjetiva, e segunda mais voltada para a objetividade, revela que essa melancolia não só do eu lírico, é do brasileiro também. No verso que fecha o poema, pela lógica da segunda estrofe, espera-se um "Tão Brasil". Mas o que aparece é a recuperação do refrão da primeira parte do poema, em primeira pessoa, "Eu tomo alegria!". Algo mais particular se mistura à estrofe que traz algo de política e algo mais geral: tão Brasil, tão cordial.

"Não sei dançar" responde ao movimento modernizador do Brasil com constantes referências ao passado colonial, organizadas no presente, que representam uma forte permanência de estruturas sociais coloniais, sendo que tais estruturas são antagônicas com a 
ideia de modernidade. No poema, a conciliação, aparente, desse antagonismo, marca do Brasil, evidencia o conflito existente. Ainda, o eu-lírico observa o presente em relação ao passado de forma melancólica e não precisa fazer uma volta ao passado para isso, a realidade dessa festa de Carnaval, que sintetiza o Brasil, já fornece os dados do passado.

Para isso, o poema, primeiro, traça a melancolia pessoal da voz poética, que também se relaciona com essa passagem para um Brasil moderno enfrentada na época, contexto da cordialidade, pois a forma com que o eu-lírico primeiro apresenta questões individuais ao leitor, para, depois, apresentar dilemas tão brasileiros, é cordial, como vimos nos outros poemas analisados neste trabalho.

O eu-lírico afirma, melancolicamente, que já perdeu pai, mãe, irmãos, afirma o rompimento de um contex to familiar. A cordialidade, entretanto, impõe que esse contexto não seja rompido. Essa melancolia não é só do poeta, é brasileira e histórica. A segunda parte do poema pressupõe a familiaridade brasileira com os elementos coloniais ressaltados ao longo da análise, com os quais não há rompimento, há permanência. Ainda, embora o eu-lírico não dance no baile, ele está lá, entende e participa de tudo isso. Ao mesmo tempo, ele assiste e pode evidenciar as observações transmitidas, mas só depois de criar uma relação de familiaridade com o leitor, com os fatos íntimos das primeiras estrofes.

\subsubsection{Os velórios cordiais e a tradição viva}

Como foi abordado anteriormente, as crônicas podem ajudar o leitor de Bandeira a iluminar alguns aspectos dos poemas, principalmente quando pertencem a um mesmo contexto sócio histórico e têm uma preocupação com a dimensão do "retrato brasileiro" moderno. As crônicas "Velório" e "Bahia" trazem mais claramente, pela própria natureza da crônica, expedientes cordiais, tanto na temática como na forma.

Mais claramente também as crônicas se aproximam do leitor. Afinal, "esse gênero de literatura ligada ao jornal está entre nós há mais de um século e aclimatou com tão naturalidade, que parece nosso. Despretensiosa, próxima da conversa e da vida de todo o dia, a crônica tem sido (...) companheira quase que diária do leitor brasileiro” (ARRIGUCCI, 1987, p. 51). Como vimos, nas crônicas de Bandeira, o tom coloquial de conversa é adotado e, como nos poemas, serve como caráter de aproximação ao leitor. Isso está presente também nas crônicas "Velório" e "Bahia". 
"Velório" é um texto publicado no Boletim Ariel, um mensário crítico-bibliográfico, em dezembro de 1936. Em um momento de modernização mais intensa, descreve-se um velório no Rio de Janeiro com descrições muito provincianas e cordiais.

Para isso, parte da obra "Velório", de Rodrigo M. F. de Andrade, e elenca as características cordiais do velório carioca, a "conversa mole", "a cordialidade efusiva", a “criada amável” servindo.

Em poema com um tema similar, um enterro, "Momento num café", já se identificou a cordialidade presente. Jerônimo Teixeira (2005), a partir desse poema, diferencia polidez e cordialidade. No poema, a primeira estrofe retrata homens que "tiram o chapéu maquinalmente" quando o enterro passa, algo mais de um gesto mecânico da vida moderna e obedecendo um código social, mas há um homem que tem um gesto "longo e demorado" em uma expressão espontânea e uma afetividade que transborda, diferente daquele gesto maquinal. Os que fazem o gesto mecânico estão mais próximos da polidez, já o homem com o gesto "longo e demorado" estão mais próximos do conceito em torno do "homem cordial".

O velório da crônica é, pois, diferente da polidez. Para Sério Buarque, "nenhum povo está mais distante dessa noção ritualista da vida do que o brasileiro" (HOLANDA, 1963, p. 137). Na crônica, isso salta aos olhos. Os velórios descritos vão além da convenção social e de um formalismo. Os acontecimentos são muito mais espontâneos do que a ocasião pediria e o que marca é o traço cordial em receber as visitas; tanto que o leitor quase esquece que é para um velório:

Quase sempre é café que vem. Desta vez, foi vinho do Porto e biscoitos Maria. Seu Aderne, que não tinha jantado, gostou do vinho e dos biscoitos, ascendeu em seguida um cigarro, e "insensivelmente", diz o autor de Velórios, "foi sendo atraído pela conversa" de um certo Vilaça (...) (BANDEIRA, 2006, p. 203).

O próprio texto marca ser uma expressão natural, espontânea, o que se aproxima da cordialidade e se afasta da polidez: "um sujeito - naturalmente com a caridosa intenção de aliviar o meu estado de espírito - tentou envolver-me na sua conversa mole" (BANDEIRA, 2006, p. 203; grifo nosso). Na aparente polidez em aliviar o filho do morto, tem-se, na verdade, "manifestações que são espontâneas no 'homem cordial”" (HOLANDA, 1963, p. 138).

Assim como as situações descritas da crônica, no texto em si, pouco se fala de morte, mas se faz presente muitas dessas situações tão cordiais e provincianas como o servir o café pela criada amável, que nos remete à hospitalidade, virtude da cordialidade, mas também uma 
permanência ativa da "influência ancestral dos padrões de convívio humano, informados no meio rural e patriarcal" (HOLANDA, 1963, p.137).

Essa crônica responde ao processo urbanizador com expedientes cordiais, ou seja, com características de uma sociabilidade pautada em um fundo emotivo, herança do nosso passado formado na família patriarcal, opostas, a princípio, a um contexto urbanizado e modernizado. Essas características, entretanto, permanecem como padrão de convívio social. É uma permanência que afeta várias de nossas áreas em que se estabelece um convício social e se evidencia contraditório na passagem de um país mais rural para um país mais urbano.

Tal representação explícita da cordialidade se faz presente também na crônica "Bahia". O leitor é envolvido em um diálogo com uma linguagem simples, tom de conversa reforçado por comentários próximos a língua falada, como em “Mas nos tais sobradões,que nada!".

O texto foi publicado em 30 de janeiro de 1927, em uma edição de $O$ Jornal dedicado à Bahia, como está informado em notas de Crônicas da Província do Brasil. Nessa mesma nota, há trechos de cartas de Manuel Bandeira e Mário de Andrade sobre o texto:

O chateaubriand encomendou uma página de $O$ Jornal sobre igrejas e casas da Bahia para o $\mathrm{n}^{\circ}$ de 17 do corrente consagrado à boa terra, eu para ganhar duzentão vou me desunhar nesta fountainpen. Não farei nada que preste. Direi besteiras, farei reportagem. Vou encher linguiça com bosta de boi, conto histórias de carochinha, a guerra dos cem anos e pronto. (BANDEIRA, 2006, p. 270).

Há a intenção da construção textual de uma "conversa fiada". Que, se considerarmos a caracterização de poeta menor discutido no capítulo 1, fica a serviço de aproximar o leitor. A nota sobre a crônica traz trechos de outra carta sobre visita à Bahia:

Mário, estou apaixonadíssimo pela Bahia! É uma terra estupenda a cidade brasileira. Centenas centenas centenas de baitas sobradões de 4 andares e sotéia. Se eu pudesse levava um pra mim outro pra você. Solares de forte e sóbria linha senhoril com portas de pedra lavrada e brasonadas, batentes de madeira de lei com almofadões - onde moram pretinhas meretrizes e a gente pobre mais pobre deste mundo! Vocês espia por um óculo de porão onde imagina que só vive rato e vê um oratoriozinho com a lamparina de azeite queimado.

O Largo do Pelourinho é a vista urbana que um brasileiro pode mostrar a um francês sem ter nenhuma dor de corno pela perspectiva dos Campos Elíseos ou da Avenida da Ópera. Quanto casa velha bonita! Estes oitões imensos do sobrados de duas águas. A gente não se farta de olhar. Há três dias que ando com um rapaz encantador, Godofredo Filho, fazendo a corte de todas as casas velhas da Bahia. (BANDEIRA, 2006, p. 270). 
Ainda, a nota esclarece que Godofredo Filho foi funcionário do Instituto do Patrimônio Histórico e Artístico Nacional (IPHAN) e escreveu trabalhos ligados ao patrimônio histórico.

Esses trechos de carta reforçam e exemplificam o contexto de amizade vivido pelos próprios intelectuais modernistas, analisado no capítulo 2 deste trabalho, o qual influenciou as discussões intelectuais e artísticas do período. As cartas são pautadas por uma informalidade, no tom de conversa e de amizade, palavras e sentenças como "apaixonadíssimo", o diminutivo - "pretinha", "oratoriozinho" -, "se eu pudesse levava um pra mim outro pra você" exemplificam esses aspectos. Tal informalidade se estende à crônica, assim como esse encanto pelas casas velhas, associadas à discussão do patrimônio histórico.

Nessa crônica, novamente, percebe-se, a partir dos comentários ao lugar, o apego ao passado e ao provinciano. O texto já se inicia com uma imagem extremamente cordial, referindo-se a Salvador: “A gente mal pisou na cidade baixa e já se sente tão em casa como se ali fosse a grande sala de jantar do Brasil, recesso de intimidade familiar de solar antigo com jacarandás pesados e nobres. " (BANDEIRA, 2006, p. 33). Nesse trecho, prevalecem palavras que remetem a algo íntimo, familiar, tal como prefere o "homem cordial": sentir em casa, recesso de intimidade familiar.

No parágrafo seguinte, "ali a gente se sente mais brasileiro. Em mim confesso que, mais forte do que nunca, estremeceram aquelas fundas raízes sociais que nos prendem ao passado extinto, ao presente mais remoto" (BANDEIRA, 2006, p. 33), no contraste posto pelo passado extinto e o presente mais remoto, marca a contradição do passado sempre presente no Brasil.

A contradição do passado e presente e, assim, do moderno e do tradicional, continua em todo texto ("Não lhes dê (aos baianos) luz demais, como fizeram a este Rio de Janeiro, que parece automóvel noturno de novo rico"). Aqui, faz-se também vivo o progresso contraditório brasileiro, desigual em diferentes regiões.

Há, com esse contraste do novo e do antigo: "na Bahia, a tradição está viva, integrada no presente mais atual, dominando estupendamente o progressismo apressado, sovina e tapeador que tem desfigurado as nossas cidades litorâneas, que estragou completamente o meu Recife.” (BANDEIRA,2006, p. 33), além dessa problematização do progresso, tem-se uma identificação com o passado. Mas, mais do que isso, há a tentativa clara da preservação de um passado muito ligado a uma história de colonização, que se faz fortemente presente em toda história brasileira.

Como em outras crônicas, é por meio de comentários a elementos arquitetônicos da cidade que essa preservação é apresentada no texto, e também com o contraste com as 
construções mais atuais: "Mas repito: o velho ambiente, pela abundância e força de suas formas, abafa o mau gosto das construções recentes. "(BANDEIRA, 2006, p. 34).

Os casarões da Bahia chegam a ser personificados: "o espírito das velhas casas brasileiras era bem o contrário disso, caracterizando-se antes pelo ar severo, recatado, verdadeiramente senhoril." (BANDEIRA, 2006, p. 43). Recebem o ar daqueles senhores de terras do nosso passado colonial. O que, no parágrafo seguinte, é contrastado com a Modernidade, evidenciando outras contradições existentes, como a riqueza, associada ao passado e aos senhores de terra, e a pobreza, associada ao presente e ao meretrício pretinho:

parece que hoje não se gosta mais disso, mesmo na Bahia. Os velhos solares do bairro da Sé estão hoje reduzidos a cortiços de gente pobre, e é mesmo uma impressão curiosa ver o mais reles meretrício da cidade, o meretrício pretinho, aboletado em nobres casarões arruinados. (BANDEIRA, 2006, p.43).

Mesmo na crônica, gênero que é normalmente voltado para a atualidade, a voz narrativa parece constantemente abordar mais o passado. Por exemplo, ao descrever as construções das igrejas busca se remeter a um acontecimento antigo ("A dois passos da Sé Velha fica a pequena igreja da Misericórdia, onde tantas vezes pregou o padre Vieira, com claustro revertido de belos azulejos", entre outros exemplos de histórias de igrejas e construções).

A dialética passado / presente que marca o texto sugere algo que atualize valores do passado colonial em oposição ao processo de modernização, revelando contradições entre o sujeito e o seu meio. Revela ainda a perda e a permanência de lugares simbólicos buscados no espaço literário. Assim, é com essa dialética que a crônica responde criticamente ao processo de modernização brasileiro. E também com essa contradição que o texto se relaciona com a cordialidade, porque o "se sentir em casa" na Bahia se relaciona aos elementos do passado que continuam ali e às "fundas raízes", ou seja, ao que é familiar. Esse "se sentir em casa" revela como uma sensação de conforto com o mundo passado por meio dessa familiaridade. Novamente, a realidade presente já fornece dados do passado e, no conforto com esses dados, a voz lírica se encontra na contradição.

\subsection{Considerações Finais}

Com os poemas e as crônicas apresentadas neste capítulo, é possível perceber que a poesia de Manuel Bandeira capta, em suas contradições, as também contraditórias relações sociais brasileiras, não sem melancolia. Revela tensões de um país que, mesmo na modernidade, 
tem-se vivo elementos tributários de um passado, como a cordialidade. Aparece, pois, uma história perpassada pelo passado colonial e pela escravidão mesmo no presente.

Tal figuração aparece, muitas vezes, nas crônicas, relacionada a cidades transformadas pela modernidade e com um saudosismo ao arcaico por parte do eu lírico. Nesses textos, o olhar crítico da modernização da sociedade brasileira também se faz presente e, pela própria natureza do gênero, ilumina, abordando mais claramente, alguns aspectos pouco referências da poesia.

As cidades brasileiras representadas ali estão carregadas das contradições da realidade histórica, já que, nessas cidades, há um espaço de disputa. Tal disputa se dá inclusive entre as raízes rurais e patriarcais e com as implicações que a nossa história colonial e escravocrata traz, algo tão vivo e tão presente na sociedade brasileira atual.

Disputas que estão em "Evocação a Recife", com a cidade natal do eu- lírico e sua atmosfera rural, e não moderna, fornecendo um dado profundo do Brasil, e não a afirmação e a simples reprodução de uma ideologia tradicional e colonial ou uma simples melancolia com o fato do Brasil se modernizar. Vimos que a maneira que o eu-poético se projeta para o passado, mediada pela infância, é uma valorização de um passado que ele deseja ou um passado que permanece, o que responde ao processo de modernização brasileiro e traz uma relação com a cordialidade pela forma em que o poema busca atrair um leitor, com tudo atravessado pelo particular e íntimo, negando as grandes abstrações. O poema se vale de imagens particulares e provincianas para trazer o dilema do moderno e do tradicional na sociedade brasileira. Além de se colocar como parte desse dilema, o eu-poético, a partir dessa forma cordial, também coloca o leitor.

Em "Como era o Pernambuco de 1821", traz a representação de um mundo cordial contraditório, por exemplo com os usos do diminutivo e a recepção cordial do brasileiro. E nos ilumina sobre como a saudade de uma época, sendo uma "paixão anacrônica", que responde criticamente ao processo modernizador, é também história e contraditória.

As disputas entre as raízes rurais e patriarcais e a modernidade estão, inclusive, na cidade do "Poema tirado de uma notícia de Jornal", em uma cidade com uma vida urbana e mecanizada. O cotidiano da notícia de jornal permanece na poesia e está ali a nossa experiência história, social e política sintetizada em poucos versos. Novamente, há a criação de empatia do leitor, pois o poema, situando-se, cordialmente, entre a literatura e a notícia, capta a sensibilidade desse leitor e coloca o destino do João Gostoso como algo que pertence à experiência na cidade moderna. João Gostoso, assim como o poema, está à margem dessa cidade e sintetiza a violência do cotidiano desse país urbanizado, marcado pelo desequilíbrio social perpetua uma violência também presente nas nossas raízes coloniais. 
Em "A trinca do Curvelo", vemos novamente uma reposta ao progresso contraditório com indivíduos à margem da sociedade, mas agora são crianças de um lugar pobre do Rio de Janeiro. Sendo uma crônica que se relaciona à cordialidade com a criação de um afeto em torno dessas crianças, na presença de uma ética de fundo emotivo, tal como bem conhece o "homem cordial". E utiliza dessa forma cordial para abordar a pobreza e os dilemas que invadem uma cidade em processo de modernização.

Assim como em "Irene no céu", um poema em que questões históricas podem ser pensadas. Há, nas falas de São Pedro e de Irene, a síntese das nossas relações sociais, em relação à camada dominante e ao subalterno, transparecendo, mas cordialmente e de forma sutil, o que faz parte da escravidão e de uma moral sinuosa até na violência. Uma dialética harmonia/violência que está na escravidão, parte da história brasileira, no progresso, marcado pelo atraso e pelas contradições de uma vida que por muito tempo permaneceu rural e apoiada na escravidão, e, ainda, na própria forma do poema, que usa dessa forma sutil e harmônica para captar o leitor para esses dilemas, mostrando-lhe que dados do passado também permanecem nele.

Em "Não sei dançar", explicitamente se fala do Brasil, mas a relação com o passado é sutil, apesar de constantes. Essa relação traz referências ao passado colonial no momento presente do poema, em que aspectos novos não valem mais que os antigos. Nisso há a participação do eu-poético, embora distanciada por não saber dançar, e do leitor, que, novamente, primeiro é atingido por fatos íntimos e particulares para só assim entrar em contato com uma realidade contraditória e problemática, evidenciada e sintetizada em uma festa de Carnaval.

Em "Velório" e "Bahia", com a característica formal das crônicas de se assemelharem a uma conversa com o leitor, o que, como vimos, tão bem se relaciona à cordialidade, são evidenciados expedientes cordiais como resposta ao processo de urbanização. Em "Velório", há um padrão de convívio social formado na nossa sociedade patriarcal, pautado em uma espontaneidade que se difere da polidez. Em "Bahia”, há um conforto em encontrar na Bahia aspectos do passado, mediado pela questão arquitetônica, iluminando aspectos como a problematização do progresso e a identificação com o passado.

Nesses textos, antagonismos históricos estão na obra de Bandeira. O poeta, em um momento em que é cercado pela urbanização crescente, observa com uma consciência muito forte a passagem modernizadora do Brasil mais rural para o Brasil mais urbano. Todos os textos citados, de maneira bem diferentes, captam o movimento dessa experiência de passagem. Os poemas e crônicas constatam o passado e evidenciam uma realidade presente com dados do 
passado, em muitos há um reconforto em se encontrar com esse passado tão familiar de forma sutil. O eu-poético entende o seu pertencimento e sua participação a isso e coloca o leitor também como partícipe.

Há também um trabalho lírico com o progresso brasileiro e constatação de que ele chega com uma forma sobretudo familiar e com a perpetuação de um esquema de violência.

Com todos os elementos discutidos aqui, é possível pensar que a obra de Bandeira, ao mesmo tempo que representa um mundo cordial, há o uso de uma forma também cordial. Elementos nacionais se incorporam à própria forma poética, que é ambivalente, assim como a cordialidade.

Tal forma cordial é usada para afetar um leitor, para captar a cordialidade de um sujeito que pode nem perceber sua participação nesse dado histórico brasileiro. O contato com o leitor por meio da construção lírica da humildade bandeiriana, como foi trabalhado no capítulo 1, é, então, ditado por uma ética de fundo emotivo que tudo quer familiarizar e que entende como pouco acessível a compreensão de uma ordenação impessoal, essa ética é parte de um povo em que sempre se destacou a supremacia do núcleo familiar, tendo como efeito, segundo Sérgio Buarque de Holanda, as relações que se criam na vida doméstica como modelo de qualquer composição social.

Com a permanência dessas heranças do passado na modernidade, há sempre a relação com o passado. Nessa relação, apresenta-se, diferente de outros poetas brasileiros modernos, como Carlos Drummond de Andrade, uma celebração, que é íntima, há um afeto com o que passou, com a infância ou até com um passado que nem mesmo conheceu. O que se releva é um passado não superado que é brasileiro, e tudo é atravessado pela intimidade, tal como faz o nosso "homem cordial", entendido em sua importante contradição do privado e do público.

Nos textos, então, encontram-se antíteses como passado e presente, modernização e retrocesso, alegria e melancolia, capitalismo e ruralismo, público e privado, rural e urbano. A obra de Bandeira concilia esses elementos opostos, aspectos que não são só do poema, mas da sociedade brasileira, sendo brutalmente associados, mesmo tão inconciliáveis.

Várias dessas contradições são, aparentemente, resolvidas no espaço dos poemas pela familiaridade com o leitor ou por esse passado íntimo, o que destaca que um problema brasileiro ganha forma poética. Assim também ideias frente à modernização no período, como a defesa do patrimônio histórico, encontra forma na arte de Bandeira.

Em tudo isso, faz-se presente a preocupação modernista com a realidade do país. Um país, atravessado por contradições de um desenvolvimento pautado no atraso, com o que se chocava o avanço da modernização e da urbanização vivenciados pelos modernistas, que 
experimentavam profundamente a contradição do moderno e tradicional, também nas discussões sobre os avanços estéticos.

E assim se constrói o nacionalismo singular de Manuel Bandeira, que parece expressar tudo com uma simplicidade e a inocência de uma criança, tal como as brincadeiras de infância ou os pensamentos infantis do narrador de "Evocação do Recife". Entretanto, o tom cordial e a familiaridade na dicção remetem também a uma observação crítica da sociedade brasileira em um contexto histórico que vive uma urbanização crescente e problemática, é o progresso contraditório. Daí a vigência não conservadora da obra de Bandeira, que se alimenta de fundamentos da sociedade patriarcal mais atrasada para mostrar as contradições do progresso brasileiro. 


\section{CONSIDERAÇÕES FINAIS}

Neste estudo, procuramos examinar certa poesia e crônica de Manuel Bandeira considerando o contexto dos decênios de 1920 e 1930 e destacando a ideia modernista de redescobrir o Brasil, que se encontra na tensão entre dois momentos, um mais otimista dessa redescoberta e outro marcado por uma maior consciência do atraso do subdesenvolvimento. $\mathrm{O}$ que em Bandeira se realiza com temáticas relacionadas à poesia moderna, ou seja, na valorização do popular, no contato com o cotidiano etc., e com a liberdade dessa poesia, com versos livres, com frases curtas e com simplicidade sintática e lexical. Porém, tais aspectos da poesia moderna são perpassados por um saudosismo e um tom melancólico que contrasta com as ideias da fase eufórica do modernismo e observa criticamente o progresso contraditório.

Apresentamos inicialmente as mudanças políticas, econômicas, sociais e culturais enfrentadas pelo Brasil no período citado. Nesse contexto, encontra-se o forte empenho em relação à interpretação do Brasil entre os intelectuais e escritores cuja expressão literária, que desde o Romantismo desenvolveu esquemas de interpretação do país e contribuiu para a formação de uma Identidade Nacional, desempenhou um papel significativo. Empenho que, conforme analisamos, está também e de modo peculiar nos textos bandeirianos.

No mesmo contexto, encontra-se o desenvolvimento da ideia de "homem cordial", a partir do clássico Raízes do Brasil, em que Sérgio Buarque de Holanda (1963) conclui como característica marcante do brasileiro a cordialidade. Tal categoria desenvolve-se em relação ao processo histórico brasileiro e define algumas das contradições essenciais do país, que têm suas raízes na colonização, tais como, por exemplo, a existente na marca determinante do particular na esfera pública, que atinge a vida política, religiosa e cultural. É um conceito que carrega a ambiguidade de um caráter afetivo e da simpatia que revelam, desde a escravidão, uma violência que se perpetua mesmo com o avanço da urbanização. A cordialidade envolve o modo como operam os padrões de comportamento na sociedade brasileira de forma que o arcaico da nossa história de colonização é atualizado pela modernização:

é possível acompanhar, ao longo de nossa história, o predomínio constante das vontades particulares que encontram seu ambiente próprio em círculos fechados e pouco acessíveis a uma ordenação impessoal. Dentre esses círculos, foi sem dúvida o da família que se exprimiu com mais força e desenvoltura em nossa sociedade. E um dos efeitos decisivos da supremacia incontestável, absorvente do núcleo familiar - a esfera, por excelência dos chamados "contatos primários", dos laços de sangue e de coração - está em que as relações que se criam na vida doméstica sempre fornecem o modelo obrigatório social entre nós. Isso ocorre mesmo onde as instituições 
democráticas, fundadas em princípios neutros e abstratos, pretendem assentar a sociedade em normas antiparticularistas. (HOLANDA, 1963, p. 136).

Vimos que essa realidade histórica da cordialidade, que quer ditar todas as formas de convívio por uma ética de fundo emotivo e na lógica da amizade, faz-se presente também na escrita modernista e nas relações de convívio entre intelectuais, escritores e críticos. Além disso, foram identificados elementos na obra bandeiriana que traduzem esteticamente o "homem cordial”, algo que está presente principalmente se considerarmos a voz lírica e narrativa como espaço de ambiguidades.

Constatou-se no eu-lírico bandeiriano uma saudade melancólica da época da infância com constantes referências à sociedade colonial em uma crítica à modernização e à crescente urbanização. Esse saudosismo, também característica de um "homem cordial", aparece em vários textos atravessados pelo íntimo e pelo particular, pela família, apresentando a característica da cordialidade que tudo quer tornar próximo e familiar. No espaço dos poemas e das crônicas, o Brasil patriarcal constantemente retorna nessa poesia moderna e o eu-poético se apresenta através da revelação de um pertencimento a essas contradições, localizando-se na contradição entre o antigo e o novo.

Além disso, a voz do eu-lírico bandeiriano envolve-se de uma humildade ambivalente que é poeticamente construída, resultando no seu estilo aparentemente simples e na humildade, também aparente, de poeta menor. Vimos essa simplicidade e essa humildade como forma de criar empatia com um leitor para, assim, revelar algo mais complexo. Nas crônicas, estabelecese uma intimidade com o leitor por meio das características formais que aproximam esse tipo de texto de uma conversa entre amigos. Ainda, a sua construção da mitologia pessoal e os fatos íntimos, denominados como pequenas alegrias e tristezas, também cumprem essa função. Em vários momentos, o ritmo ou um tom harmônico construído no poema também parece atrair o leitor, mas, sutilmente, apresenta-se a ambiguidade dessa harmonia em uma violência característica das relações sociais brasileiras, herdada de práticas escravocratas e coloniais.

Dessa forma, afirma-se que a voz lírica e narrativa em Bandeira parece considerar um leitor cordial, que tem horror às distâncias, que tudo tenta tornar próximo e que baseia suas relações em critérios de simpatia. Considerando isso, o leitor também é colocado como parte do dilema do atraso brasileiro, do progresso contraditório e da permanência de aspectos coloniais na sociedade moderna.

Assim, vimos que Manuel Bandeira usa uma forma cordial para captar um sujeito. Diferente de outros poetas modernistas, como Oswald de Andrade e Drummond, cordialmente, 
estabelece um contato íntimo com o seu leitor para, assim, captar uma cordialidade que o leitor às vezes nem reconhece que tem. Tal contato íntimo com o leitor sublinha a peculiaridade do nacionalismo modernista de Bandeira em sua forma poética e prosaica.

Percebemos, ainda, ao longo do trabalho que, com um incrível poder de síntese poética, Manuel Bandeira discute questões que a associação com a cordialidade nos leva a melhor enxergar, tais como o choque entre o rural e o urbano e moderno, a predominância do privado em relação ao público, e deixa transparecer, pela forma ambígua e com tensões, um movimento amplo da história.

Há nos poemas e nas crônicas, representações de aspectos da cordialidade, como é o aspecto linguístico do diminutivo, que também serve para familiarizar e aproximar. Assim como o tratamento com a religião que, em Bandeira, dá-se com a proximidade dos santos comum ao "homem cordial". Espaços públicos também são tornados particulares e vários personagens ganham a caracterização de cordiais: são conversadores ou bonachões. Ainda, há um afeto familiar e uma dependência da família que merece atenção. E a relação com o passado, diferente de outros modernistas, não é de superação ou de simples celebração, é de intimidade, é um passado íntimo, ainda vivo.

Com tudo que foi discutido, percebe-se que os textos literários sugerem a noção de cordialidade, revelando contradições sociais estruturantes da vida brasileira e a contradição da modernização no Brasil. Isso se dá tanto com as representações de expedientes cordiais, como com uma forma cordial, que merece ser mais estudada por constituir um algo que nos ajuda a entender e superar as contradições brasileiras, além da cordialidade ser uma referência produtiva para pensar criticamente a literatura brasileira e a obra de Bandeira.

Entretanto, vimos também que a melancolia da obra de Bandeira vai em direção contrária à cordialidade que tudo busca conciliar. A poética bandeiriana usa dessa conciliação cordial, já que, nos textos, contradições brasileiras, como o rural e o urbano, são resolvidos a partir da familiaridade. Mas justamente por meio dessa conciliação, que parece ser negadora dos conflitos da realidade, realça esses conflitos, podendo ser considerada de dois gumes, já que ao parecer reforçar uma realidade unilateral, dialeticamente, revela algo muito mais complexo. Pensando com Candido, a obra de Manuel Bandeira, "justamente pelo fato de manter relação com a realidade social, a literatura incorpora as suas contradições à estrutura e ao significado da obra" (CANDIDO, 2000, p. 168).

Por fim, na pesquisa, foi possível examinar como as contradições da experiência histórica brasileira, assim como do processo de modernização, acontecem nos poemas. Buscou- 
se contribuir para uma compreensão da obra de Manuel Bandeira que considera as ambiguidades e apresenta novas questões na temática do nacionalismo dessa obra.

Vale destacar que o que importa não é se o pensamento de Manuel Bandeira se configura em um conservadorismo que considera a vigência do mundo patriarcal ou não. O que se vê não é a afirmação positiva da ideologia patriarcal, mas como a arte de Bandeira compreende as tensões de uma época que se encontra na contradição do processo de modernização e na presença de dados do passado se perpetuando no presente. As contradições da realidade brasileira pedem forma e a obra de Manuel Bandeira dá a elas uma forma coerente que, por ser o próprio depoimento da nossa situação brasileira em relação ao universal, extrapola os condicionamentos particulares que nela são tão evidentes. 


\section{REFERÊNCIAS BIBLIOGRÁFICAS}

ADORNO, Theodor. "Lírica e sociedade", in: Textos escolhidos - Walter Benjamin, Max Horkeimer; Theodor W. Adorno, Jürgen Habermas. São Paulo: Abril Cultural, 1983.

ANAN, Sylvia Tamie. Crônica da vida inteira: memórias da infância nas crônicas de Manuel Bandeira. Dissertação (Mestrado em Literatura) - Universidade de São Paulo, São Paulo, 2006.

ANDRADE, Mário. “O movimento modernista” in: Aspectos da Literatura Brasileira. 6. ed. Belo Horizonte: Itatiaia, 2002.

ARRIGUCCI JR., Davi. Fragmentos sobre a crônica. In: Enigma e comentário. São Paulo: Companhia das letras, p. 51-65, 1987.

Letras, 1990.

Humildade, paixão e morte: a poesia de Manuel Bandeira. São Paulo: Cia das

ASSIS, Machado de. Instinto de nacionalidade \& outros ensaios. Porto Alegre: Mercado Aberto, 1999.

BACIU, Stefan. Manuel Bandeira de Corpo Inteiro. Rio de Janeiro: José Olympio, 1966.

BANDEIRA, Manuel. Estrela da vida inteira: Poesia Completa. 5. ed. Rio de Janeiro: Nova Fronteira, 2009.

. Flauta de Papel. São Paulo: Global, 2008.

Itinerário de Pasárgada. São Paulo: Global, 2012

Crônicas da província do Brasil. São Paulo: Cosac Naify, 2006.

BASTOS, Hermenegildo (org.); ARAÚJO, Adriana (org.). Teoria e prática da critica literária dialética. Brasília: Editora Universidade de Brasília, 2011.

- "Tragédia histórica e o progresso contraditório como elementos formais da crítica literária." In: Revista eletrônica: Herramienta. Buenos Aires, 2014. Disponível em $<$ http://www.herramienta.com.ar/coloquios-y-seminarios/tragedia-historica-e-o-progressocontraditorio-como-elementos-formais-da-crit>. Acesso em: 10 nov. 2016, 10:00:00.

BENJAMIN, Walter. Obras escolhidas. 3 vols. São Paulo: Brasiliense.

BEZERRA, Elvia. Ribeiro Couto e o homem cordial. Disponível em <http://www.academia.org.br/abl/media/prosa44c.pdf.> Acesso em: 3 nov. 2016, 8:00:00.

BOSI, Alfredo. História Concisa da Literatura Brasileira. 43. ed. São Paulo: Cultrix, 2006.

CANDIDO, Antonio. "A revolução de 1930 e a cultura" in: Novos Estudos Cebrap, São Paulo, v. 2, 4, p. 27-36, 1984. 
1993.

“Dialética da malandragem”. In: O discurso e a cidade. São Paulo: Duas cidades,

. "Literatura e Cultura de 1900 a 1940" in: Literatura e Sociedade. São Paulo:

Publifolha, 2000.

."Literatura de dois gumes" e "Literatura e subdesenvolvimento" in: A educação pela noite outros ensaios. 3. ed. São Paulo: Ática, 2000.

. "O significado de Raízes do Brasil." In: SANTIAGO, Silviano (Coord.) Intérpretes

do Brasil. Rio de Janeiro: Nova Aguilar, 2002c. $2^{a}$ edição. Vol. 3. pp.931-941.

Recortes. São Paulo: Companhia das Letras, 1993.

CANDIDO, Antonio; SOUZA, Gilda de Mello e. "Estrela da vida inteira." in: BANDEIRA, Manuel. Estrela da vida inteira: Poesia Completa. 5. ed. Rio de Janeiro: Nova Fronteira 2009.

DIAS, Maria Odila Leite. "Política e sociedade na obra de Sérgio Buarque de Holanda". In: CADIDO, Antonio. Sérgio Buarque de Holanda e o Brasil. São Paulo: fundação Perseu Abramo, 1998.

DIAS, Silvana Moreli Vicente. Matizes da cordialidade: a correspondência de escritores e inflexões dos debates no modernismo brasileiro. Crítica Cultural (Critic), Palhoça, SC, v.8, n. 2, p. 353-369, 2013.

FAUSTO, Boris. História Concisa do Brasil. São Paulo: Editora Universidade de São Paulo, 2006.

FLORES JR, W. J. "Inconciliáveis carvoeirinhos: ambivalências em "Meninos carvoeiros", de Manuel Bandeira”. Texto Poético, v. 8, 2010.

.Reflexões sobre o cotidiano na poesia de Manuel Bandeira". Revista Garrafa (PPGL/UFRJ), v. 27, p. 14, 2012.

."Vou-me embora pra Pasárgada: devaneio e processo social". Revista Cerrados (Brasília. Online), v 24, p. 311-325, 2015.

FREDERICO, C. A arte no mundo dos homens. São Paulo: Expressão Popular, 2013.

FREYRE, Gilberto de Melo. Casa-grande \& senzala. 12ª edição. Brasília: Editora Universidade de Brasília, 1963.

. Sobrados e mucambos: decadência do patriarcado rural e desenvolvimento urbano.

São Paulo: José Olympio, 1951.

GUIMARÃES, Júlio Castañon. Crônica das Crônicas da província do Brasil. In:

BANDERIA, Manuel. Crônicas da província do Brasil. São Paulo: Cosac Naify, 2006. 
HERINGER, Victor. "O Jayme Ovalle de Manuel Bandeira”. Revista Memento (Revista do mestrado em Letras, Linguagem, Discurso e cultura - UNINCOR), v.3, n.2, 2012.

HESS, Elisabeth Ingeburg Souza. Uma análise do realismo na constituição do eu-lírico na poesia de transição de Bandeira. Dissertação (Mestrado em Literatura) - Universidade de Brasília, Brasília, 2014.

HOLANDA, Sérgio Buarque de. Raízes do Brasil. Brasília, Editora Universidade de Brasília, 1963.

."Trajetória de uma poesia”. In: Cobra de vidro. São Paulo: Martins, 1944.

JARDIM, Mara Ferreira. Manuel Bandeira: Tão Brasil! Tese (Doutorado em Literatura Brasileira) - Universidade Federal do Rido Grande do Sul, Porto Alegre, 2007.

JUNQUEIRA, Ivan. "Libertinagem e o verso livre" e "Bandeira e o Modernismo" in:

Testamento de Pasárgada. Manuel Bandeira; organização e estudos críticos de Ivan Junqueira. Rio de Janeiro: Nova Fronteira, 2003.

KISHIMOTO, Tisuko Morchida. Jogos Infantis - O jogo, a criança e a educação. $12^{\text {a }}$ edição. Petrópolis, RJ: Vozes, 2004.

LAFETÁ, João Luiz. Estética e ideologia: o Modernismo em 30. In: A dimensão da noite. Org. de Antonio Arnoni Prado. São Paulo: Duas cidades; Ed. 34, 2004

LUKÁCS, Georg. A teoria do Romance. Trad. De José Marcos Mariani de Macedo. São Paulo: Duas cidades/Editora 34, 2000.

NETO, Godofredo de Oliveira. "Bandeira, modernista brasileiro". In: BANDEIRA, Manuel. Libertinagem \& Estrela da Manhã. Rio de Janeiro: Nova Fronteira, 2005.

PRADO, Antonio Arnoni. Dois letrados e o Brasil nação: a obra crítica de Oliveira Lima e Sérgio Buarque de Holanda. São Paulo: Editora 34, 2015.

Raízes do Brasil e O Modernismo. São Paulo: Novos Estudos Cebrap, v. 1, n.50, p. 211-218, 1998.

PRADO Jr., Caio. Formação do Brasil Contemporâneo. São Paulo: Companhia das Letras, 2000.

RICUPERO, Bernardo. O Romantismo e a Ideia de Nação no Brasil (1830-1870). São Paulo: Martins Fontes, 2004.

ROCHA, João Cezar de Castro. Literatura e cordialidade: o público e o privado na cultura brasileira. Rio de Janeiro: EdUERJ, 1998.

O exílio do homem cordial. Rio de Janeiro: Ed. Museu da República, 2004.

ROSENBAUM, Yudith. Manuel Bandeira: uma poesia da ausência. Rio de Janeio: Imago, 1993. 
SANTIAGO, Silviano. "Liminar: um poeta trágico.” In: LANCIANI, Giulia (Coord.). Libertinagem - Estrela da Manhã: Edição crítica. Espanha: ALLCA XX, p.XIX-XXV, 1998.

SCHWARZ, Roberto. As ideias fora do lugar: ensaios selecionados. São Paulo: Companhia das Letras, 1987.

Um mestre na periferia do capitalismo: Machado de Assis. São Paulo: Duas cidades. Ed. 34, 2000.

Sequências brasileiras: ensaios. São Paulo: Companhia das Letras, 1999.

SOUZA, Jessé. A tolice da inteligência brasileira ou como o país se deixa manipular pela elite. São Paulo: LeYa, 2015.

TELES, Gilberto Mendonça. “A experimentação poética de Bandeira em Libertinagem e Estrela da manhã” In: LANCIANI, Giulia (Coord.). Libertinagem - Estrela da Manhã: Edição crítica. Espanha: ALLCA XX, p. 105-155, 1998.

TEIXEIRA, Jerônimo. Drummond Cordial. São Paulo: Nankin Editorial, 2005.

Drummond afirma que a crônica é um instrumento de registro histórico. Disponível em: < http://www.contioutra.com/drummond-afirma-que-a-cronica-e-um-instrumento-de-registrohistorico/>. Acesso em: 5 jul. 2015, 12:20:00. 